\title{
Total Synthesis of Seongsanamide B
}

\author{
Sadegh Shabani and Craig A. Hutton* \\ School of Chemistry and Bio21 Molecular Science and Biotechnology Institute, \\ The University of Melbourne, Victoria, Australia, 3010
}

\section{Supplementary Information}

\section{Contents}

General Information

Experimental Procedures

S3-S27

NMR and mass spectra, HPLC traces

S28-S60

Comparison of ${ }^{1} \mathrm{H}$ and ${ }^{13} \mathrm{C}$ NMR data for synthetic and natural seongsanamide B 2

S61

References

S62 


\section{General Information}

${ }^{1} \mathrm{H}$ NMR spectra were recorded using an Agilent $500(500 \mathrm{MHz})$ or a Varian Unity Inova 400 (400 $\mathrm{MHz})$ or a Varian Unity Inova $600(600 \mathrm{MHz})$. Spectra were obtained in $\mathrm{CDCl}_{3}$ (7.26) or $\mathrm{d}_{6} \mathrm{DMSO}$ (2.50). The spectra are reported as: parts per million ( $\mathrm{ppm})$ downfield shift, relative to the residual solvent peak; relative integral, multiplicity $(\mathrm{s}=$ singlet, $\mathrm{br}=$ broad, $\mathrm{d}=$ doublet, $\mathrm{t}=$ triplet, $\mathrm{q}=$ quartet, $\mathrm{dd}=$ doublet of doublets, $\mathrm{dt}=$ doublet of triplets, $\mathrm{dq}$ doublet of quartets, $\mathrm{m}=$ multiplet ) and coupling constant $\left(\mathrm{J}\right.$ in Hz). ${ }^{13} \mathrm{C}$ NMR spectra were recorded using an Agilent $500(125 \mathrm{MHz})$ or a Varian Unity Inova $600(150 \mathrm{MHz})$. Chemical shifts $(\delta)$ are reported in parts per million (ppm) relative to the internal standard of the solvent peak; $\mathrm{CDCl}_{3}$ (77.16) and DMSO (39.52). All mass spectra were recorded on an MSFP OrbiTRAP infusion Mass Spectrometer. Most reagents were commercially available reagent grade chemicals and were used without further purification. DMSO was distilled over calcium hydride. Anhydrous THF, $\mathrm{Et}_{2} \mathrm{O}$, DMF and $\mathrm{CH}_{2} \mathrm{Cl}_{2}$ were obtained from a solvent drying and dispensing system where the solvent was dried by passage through two packed columns of neutral alumina. Powdered molecular sieves were activated with a microwave and allowed to cool under vacuum. Analytical thin layer chromatography was performed with aluminium backed plates precoated with silica gel 60 F254 $(0.2 \mathrm{~mm})$, and visualisation was achieved by inspection under shortwave UV light followed by staining with phosphomolybdic acid dip [polyphosphomolybdic acid (12 g), ethanol (250mL)]. Flash chromatography was performed using silica gel (230-400 mesh); eluting solvents reported as \% v/v mixtures. Analytical, preparative and chiral reverse phase HPLC (RPHPLC) were performed using an Agilent 1200 series LC System. Analytical HPLC employed a Discovery C18 column $\left(4.6 \times 150 \mathrm{~mm}\right.$ column, $5 \mu \mathrm{m}$ particle size, flow rate of $\left.1 \mathrm{~mL} \mathrm{~min}^{-1}\right)$. Preparative RP-HPLC employed a Phenomenex C18 column $(21.2 \times 150 \mathrm{~mm}, 5 \mu \mathrm{m}$ particle size, flow rate $8 \mathrm{~mL}$ min-1). The mobile phase consisted of eluents A $(0.1 \%$ TFA in water) and B $(0.1 \%$ TFA in acetonitrile). The results were analysed on Agilent ChemStation version B.01.03 software. 


\section{Experimental Procedures}

\section{Benzyl (S)-3-(3-acetyl-4-(benzyloxy)phenyl)-2-((diBoc)amino)propanoate}

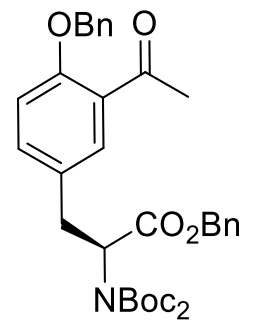

Following the reported procedure, ${ }^{1}$ Anhydrous aluminium chloride (29.83 g, $224 \mathrm{mmol}$ ) was added dropwise to a solution of L-tyrosine $(10 \mathrm{~g}, 55.2 \mathrm{mmol})$ in dry nitrobenzene $(220 \mathrm{ml})$ at room temperature. The reaction was stirred at room temperature for $10 \mathrm{~min}$. Acetic anhydride $(4.8 \mathrm{ml}, 51$ mmol) was added dropwise over $5 \mathrm{~min}$ and mixture was stirred for $6 \mathrm{~h}$ at $100{ }^{\circ} \mathrm{C}$. The reaction was cooled down to room temperature and the thick layers were dissolved in cold $2 \mathrm{~N} \mathrm{HCl}(700 \mathrm{ml})$. The nitrobenzene layers were separated and the aqueous layers were washed with EtOAc $(2 \times 250 \mathrm{ml})$. The aqueous layers were concentrated to $150 \mathrm{ml}$ and basified with a solution of $\mathrm{NaOH}(3 \mathrm{~N})$ till the $\mathrm{pH}$ was adjusted to 8 at $0{ }^{\circ} \mathrm{C}$. $\mathrm{Boc}_{2} \mathrm{O}(13 \mathrm{~g}, 59.6 \mathrm{mmol})$ in THF $(300 \mathrm{ml})$ was slowly added to the mixture at $0{ }^{\circ} \mathrm{C}$. The ice bath was removed and the mixture was stirred at room temperature overnight. The reaction mixture was acidified using $1 \mathrm{~N} \mathrm{HCl}$ and the $\mathrm{pH}$ was adjusted to 4 . The mixture was extracted with EtOAc $(3 \times 500 \mathrm{ml})$ and the combined organic layers were washed with brine and dried over magnesium sulfate. The solvent was evaporated and dried under high vacuum before going to next step. The residue was dissolved in DMF $(100 \mathrm{ml})$ and $\mathrm{K}_{2} \mathrm{CO}_{3}(10 \mathrm{~g}, 72 \mathrm{mmol})$, benzyl bromide $(8.3 \mathrm{ml}, 70 \mathrm{ml})$, and tetraethylammonium iodide $(1.3 \mathrm{~g}, 5 \mathrm{mmol})$ were added subsequently. The reaction mixture was stirred overnight. Water $(200 \mathrm{ml})$ was added to the reaction mixture and extracted with EtOAc $(3 \times 200 \mathrm{ml})$. The combined organic layers were washed with $1 \mathrm{~N} \mathrm{HCl}(250$ $\mathrm{ml})$ and brine $(250 \mathrm{ml})$ and dried over magnesium sulfate. The EtOAc layers were evaporated and residue was dried under high vacuum and went the next step without further purification. The residue was dissolved in acetonitrile $(50 \mathrm{ml})$ and DMAP $(4.8 \mathrm{~g}, 40 \mathrm{mmol})$, and $\mathrm{Boc}_{2} \mathrm{O}(36.0 \mathrm{~g}, 165 \mathrm{mmol})$ were subsequently added at $0{ }^{\circ} \mathrm{C}$. The reaction was stirred for $12 \mathrm{~h}$ before addition of $1 \mathrm{~N} \mathrm{HCl}(200$ 
$\mathrm{ml})$ to the reaction mixture. The aqueous phase was extracted with EtOAc $(3 \times 100 \mathrm{ml})$, washed with brine $(200 \mathrm{ml})$ and dried over magnesium sulfate. The solvent was evaporated and the residue was purified using column chromatography $(10 \% \mathrm{EtOAc} / \mathrm{Hex})$ to furnish the acetylated tyrosine (21.8 g, $65 \%$ over 4 steps $)$ as a white solid. ${ }^{1} \mathbf{H}$ NMR $\left(600 \mathrm{MHz}, \mathrm{CDCl}_{3}\right) \delta 7.55(\mathrm{~d}, J=2.4 \mathrm{~Hz}, 1 \mathrm{H}), 7.43-7.35$ (m, 4H), 7.36-7.29 (m, 5H), $7.26(\mathrm{~m}, 1 \mathrm{H}), 6.91(\mathrm{~d}, J=8.5 \mathrm{~Hz}, 1 \mathrm{H}), 5.21-5.15(\mathrm{~m}, 2 \mathrm{H}), 5.13(\mathrm{~m}, 1 \mathrm{H})$, $5.11(\mathrm{~s}, 2 \mathrm{H}), 3.40(\mathrm{dd}, J=14.3,5.3 \mathrm{~Hz}, 1 \mathrm{H}), 3.19(\mathrm{dd}, J=14.3,10.1 \mathrm{~Hz}, 1 \mathrm{H}), 2.56(\mathrm{~s}, 3 \mathrm{H}), 1.35$ (s, 18H). ${ }^{13} \mathbf{C}$ NMR $\left(151 \mathrm{MHz}, \mathrm{CDCl}_{3}\right) \delta 199.4,170.1,156.8,151.7,136.3,135.5,134.6,131.4,130.1$, $128.7,128.5,128.4,128.2,128.1,127.5,112.9,83.1,70.7,66.9,59.3,34.8,32,27.9,27.8,14.2$. HRMS (ESI) $m / z:[\mathrm{M}+\mathrm{H}]^{+}$Calcd for $\mathrm{C}_{35} \mathrm{H}_{42} \mathrm{NO}_{8}$ 604.2905; found 604.2908.

\section{Benzyl (S)-2-((diboc)amino)-3-(4-(benzyloxy)-3-hydroxyphenyl)propanoate 8}<smiles>O=C(OCc1ccccc1)C(Cc1ccc(OCc2ccccc2)c(O)c1)C(=O)OCc1ccccc1</smiles>

To a mixture of the acetylated tyrosine analogue $(13.8 \mathrm{~g}, 22.8 \mathrm{mmol})$ in DCM $(250 \mathrm{ml}), \mathrm{mCPBA}$ (17.25 g, 60\% purity, $60 \mathrm{mmol}$ ) was added and the reaction mixture was stirred for 7 days. A mixture of ammonia in $\mathrm{MeOH}(70 \mathrm{ml})$ was added to the reaction mixture and the mixture was stirred overnight. ${ }^{1}$ The resulting mixture was concentrated under vacuum and the residue was diluted in EtOAc $(200 \mathrm{ml})$, washed with saturated sodium thiosulfate $(150 \mathrm{ml})$, saturated sodium bicarbonate $(150 \mathrm{ml})$, brine $(150 \mathrm{ml})$ and dried over sodium bicarbonate. The mixture was filtered and concentrated under reduced pressure. The product was purified using column chromatography (35\% EtOAc/Hex $)$ to give the product $8(9.7 \mathrm{~g}, 74 \%)$ as a transparent oil. ${ }^{1} \mathbf{H} \mathbf{~ N M R}\left(600 \mathrm{MHz}, \mathrm{CDCl}_{3}\right) \delta$ $7.42-7.37(\mathrm{~m}, 5 \mathrm{H}), 7.36-7.29(\mathrm{~m}, 6 \mathrm{H}), 6.80(\mathrm{~d}, J=8.3 \mathrm{~Hz}, 1 \mathrm{H}), 6.76(\mathrm{~d}, J=2.2 \mathrm{~Hz}, 1 \mathrm{H}), 6.62(\mathrm{dd}$, $J=8.2,2.2 \mathrm{~Hz}, 1 \mathrm{H}), 5.20-5.15(\mathrm{~m}, 2 \mathrm{H}), 5.13(\mathrm{~m}, 1 \mathrm{H}), 5.05(\mathrm{~s}, 2 \mathrm{H}), 3.35(\mathrm{dd}, J=14.2,5.0 \mathrm{~Hz}, 1 \mathrm{H})$, 
$3.12(\mathrm{dd}, J=14.2,10.2 \mathrm{~Hz}, 1 \mathrm{H}), 1.36(\mathrm{~s}, 18 \mathrm{H}) .{ }^{13} \mathbf{C} \mathbf{N M R}\left(151 \mathrm{MHz}, \mathrm{CDCl}_{3}\right) \delta 170.3,151.7,145.7$, $144.6,136.4,135.6,131.2,128.7,128.5,128.3,128.2,128.1,127.7,120.9,115.9,112.2,83.0,71.2$, 66.9, 59.6, 35.4, 27.8. HRMS (ESI) $m / z$ : $[\mathrm{M}+\mathrm{H}]^{+}$Calcd for $\mathrm{C}_{33} \mathrm{H}_{40} \mathrm{NO}_{8}$ 578.2748; found 578.2750.

\section{DOPA derivative 18}

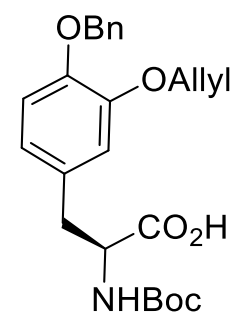

To a solution of DOPA derivative $8(4.1 \mathrm{~g}, 7.1 \mathrm{mmol})$ in DMF $(15 \mathrm{ml})$, allylbromide $(1.3 \mathrm{ml}, 14.2$ $\mathrm{ml})$ and potassium carbonate $(2.0 \mathrm{~g}, 14.2 \mathrm{mmol})$ were added and the reaction mixture was stirred for $18 \mathrm{~h}$. The solvent was evaporated and the residue was dissolved in EtOAc $(50 \mathrm{ml})$, washed with a solution of $1 \mathrm{~N} \mathrm{HCl}(50 \mathrm{ml})$, brine $(50 \mathrm{ml})$ and dried over magnesium sulfate. The organic layers were evaporated and the residue was purified using column chromatography to afford the allyl protected DOPA $18(4.0 \mathrm{~g}, 91 \%)$ as a colorless oil. ${ }^{1} \mathbf{H}$ NMR (400 MHz, $\left.\mathrm{CDCl}_{3}\right) \delta 7.42(\mathrm{~d}, J=7.1 \mathrm{~Hz}, 2 \mathrm{H})$, 7.39-7.25 (m, 8H), $6.80(\mathrm{~d}, J=8.3 \mathrm{~Hz}, 1 \mathrm{H}), 6.74(\mathrm{~d}, J=2.0 \mathrm{~Hz}, 1 \mathrm{H}), 6.67$ (dd, $J=8.3,2.0 \mathrm{~Hz}, 1 \mathrm{H}), 6.08$ (ddt, $J=17.4,10.5,5.2 \mathrm{~Hz}, 1 \mathrm{H}), 5.41$ (dd, $J=17.2,1.7 \mathrm{~Hz}, 1 \mathrm{H}), 5.26(\mathrm{dd}, J=10.5,1.6 \mathrm{~Hz}, 1 \mathrm{H}), 5.15$ (dd, $J=10.3,4.9 \mathrm{~Hz}, 1 \mathrm{H}), 4.57$ (d, $J=5.3 \mathrm{~Hz}, 1 \mathrm{H}), 3.36$ (dd, $J=14.2,5.0 \mathrm{~Hz}, 1 \mathrm{H}), 3.16$ (dd, $J=14.2$, $10.4 \mathrm{~Hz}, 1 \mathrm{H}), 1.35(\mathrm{~s}, 18 \mathrm{H}) .{ }^{13} \mathbf{C}$ NMR $\left(101 \mathrm{MHz}, \mathrm{CDCl}_{3}\right) \delta 170.3,151.9,148.6,147.4,137.5,135.6$, $133.4,130.9,128.5,128.4,128.2,128.1,127.7,127.2,122.0,117.5,115.6,115.0,82.9,71.3,69.9$, 66.9, 59.5, 35.4, 27.8. HRMS (ESI) $m / z$ : $[\mathrm{M}+\mathrm{H}]^{+}$Calcd for $\mathrm{C}_{36} \mathrm{H}_{44} \mathrm{NO}_{8} 618.3061$; found 618.3062 .

To a solution of the allyl protected DOPA $(4.0 \mathrm{~g}, 6.5 \mathrm{mmol})$ in dioxane $(20 \mathrm{ml})$, lithium hydroxide $(0.93 \mathrm{~g}, 36.0 \mathrm{mmol})$ in water $(1.0 \mathrm{ml})$ was added. The mixture was stirred for $3 \mathrm{~h}$ at room temperature, before adjusting the $\mathrm{pH}$ to 4 . Water $(100 \mathrm{ml})$ was added to the reaction and the aqueous phase was extracted with EtOAc $(3 \times 100 \mathrm{ml})$. The combined organic layers were washed with brine $(50 \mathrm{ml})$ 
and dried over magnesium sulfate. The EtOAc was evaporated and the residue was dissolved into a solution of TFA/DCM $(30 \%, 30 \mathrm{ml})$. The mixture was stirred at room temperature for $2 \mathrm{~h}$ and solvent was evaporated under reduced pressure. Further drying was done under high vacuum and residue was dissolved in a solution of THF/water (2:1, $50 \mathrm{ml})$. Sodium carbonate $(1.0 \mathrm{~g}, 9.75 \mathrm{mmol})$ and $\mathrm{Boc}_{2} \mathrm{O}$ $(2.1 \mathrm{~g}, 9.75 \mathrm{mmol})$ were added and the mixture was stirred overnight. The reaction mixture was acidified using $1 \mathrm{~N} \mathrm{HCl}$ until the $\mathrm{pH}$ was adjusted to 4 . The compound was extracted with EtOAc (3 $\times 50 \mathrm{ml})$ and the combined organic layers were washed with brine $(100 \mathrm{ml})$, before drying over magnesium sulfate. The solvent was evaporated and the residue was subjected to the column chromatography (MeOH/DCM, 5-10\%) to yield the compound 17 (2.2 g, 80\% over 3 steps) as a colorless oil. ${ }^{1} \mathbf{H}$ NMR $\left(500 \mathrm{MHz}_{,} \mathrm{CDCl}_{3}\right) \delta 7.44(\mathrm{~d}, J=7.3 \mathrm{~Hz}, 2 \mathrm{H}), 7.36(\mathrm{dd}, J=8.3,6.7 \mathrm{~Hz}, 2 \mathrm{H})$, 7.30 (t, $J=7.4 \mathrm{~Hz}, 1 \mathrm{H}), 6.84(\mathrm{~d}, J=8.2 \mathrm{~Hz}, 1 \mathrm{H}), 6.76(\mathrm{~s}, 1 \mathrm{H}), 6.69$ (d, $J=8.3 \mathrm{~Hz}, 1 \mathrm{H}), 6.16-5.99$ (m, 1H), $5.41(\mathrm{dd}, J=17.3,1.7 \mathrm{~Hz}, 1 \mathrm{H}), 5.27(\mathrm{dd}, J=10.6,2.0 \mathrm{~Hz}, 1 \mathrm{H}), 5.12(\mathrm{~s}, 2 \mathrm{H}), 4.95$ (d, $J=8.1 \mathrm{~Hz}$, 1H), $4.60(\mathrm{~d}, J=5.2 \mathrm{~Hz}, 2 \mathrm{H}), 3.11(\mathrm{dd}, J=14.1,5.5 \mathrm{~Hz}, 1 \mathrm{H}), 3.01$ (dd, $J=14.3,6.5 \mathrm{~Hz}, 1 \mathrm{H}), 1.43$ (s, 7H). ${ }^{13} \mathbf{C}$ NMR (126 MHz, $\left.\mathrm{CDCl}_{3}\right) \delta 176.3,155.4,148.7,147.9,137.3,133.4,128.9,128.5,127.8$, 127.2, 122.1, 117.7, 115.7, 114.9, 80.3, 71.2, 70.0, 54.3, 37.2, 28.3. HRMS (ESI) $m / z:[\mathrm{M}+\mathrm{Na}]^{+}$Calcd for $\mathrm{C}_{24} \mathrm{H}_{29} \mathrm{NO}_{6} \mathrm{Na} 450.1887$; found 450.1887 .

\section{Boc-4-iodo-D-Phe-OMe}

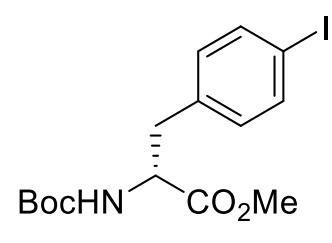

Following the reported procedure, ${ }^{2}$ iodine $(3.1 \mathrm{~g}, 12.2 \mathrm{mmol})$ and sodium iodate $(1.2 \mathrm{~g}, 6.0 \mathrm{mmol})$ were added to a solution of D-phenylalanine $(5 \mathrm{~g}, 30 \mathrm{mmol})$ in acetic acid $(28 \mathrm{ml})$ and concentrated sulfuric acid $(3.6 \mathrm{ml})$. The mixture was heated using an oil bath at $70{ }^{\circ} \mathrm{C}$ and stirred vigorously for $20 \mathrm{~h}$. Sodium periodate $(2 \times 0.12 \mathrm{~g}, 10.24 \mathrm{mmol})$ was added and the reaction was complete when the 
solution turn orange. Acetic acid was removed under reduced pressure and the solution was dissolved in water $(50 \mathrm{ml})$ and washed with diethyl ether $(2 \times 15 \mathrm{ml})$ and DCM $(2 \times 15 \mathrm{ml})$. The aqueous phase was basified to $\mathrm{pH} 5$ with a solution of $3 \mathrm{~N}$ sodium hydroxide. The white precipitate was filtered under vacuum, washed with water and cold ethanol before drying under high vacuum. The precipitate was dissolved in a mixture of water/THF $(1: 1,300 \mathrm{ml})$ and potassium carbonate $(15 \mathrm{~g}, 108 \mathrm{mmol})$ was slowly added to the reaction mixture at $0{ }^{\circ} \mathrm{C}$. Boc $2 \mathrm{O}(2.3 \mathrm{~g}, 9.4 \mathrm{mmol})$ in THF $(10 \mathrm{ml})$ was added and the reaction mixture was stirred overnight. The mixture was acidified to adjust the $\mathrm{pH}$ to 4 using a solution of $1 \mathrm{~N} \mathrm{HCl}$. The mixture was extracted with EtOAc $(3 \times 200 \mathrm{ml})$ and the combined organic layers were washed with brine $(200 \mathrm{ml})$ and dried over magnesium sulfate. The combined organic layers were evaporated and residue dried under high vacuum. The residue was dissolved in DMF $(150 \mathrm{ml})$ and potassium carbonate $(1.2 \mathrm{~g}, 9.1 \mathrm{mmol})$ and methyl iodide $(0.85 \mathrm{ml}, 13.6 \mathrm{mmol})$ were added subsequently. Reaction mixture was stirred for $18 \mathrm{~h}$ and water $(200 \mathrm{ml})$ was added. The aqueous phase was extracted with EtOAc $(3 \times 200 \mathrm{ml})$. The combined organic layers were washed with $1 \mathrm{~N} \mathrm{HCl}(200 \mathrm{ml})$, saturated sodium bicarbonate $(200 \mathrm{ml})$, brine $(200 \mathrm{ml})$ and dried over magnesium sulfate. The solvent was evaporated under reduced pressure and the residue was subjected to column chromatography ( $10 \%$ EtOAc/Hex) to provide the title compound ( $3.7 \mathrm{~g}, 75 \%$ over 3 steps) as a transparent oil. ${ }^{1} \mathbf{H}$ NMR $\left(600 \mathrm{MHz}, \mathrm{CDCl}_{3}\right) \delta 7.58(\mathrm{~d}, J=8.3 \mathrm{~Hz}, 2 \mathrm{H}), 6.85(\mathrm{~d}, J=7.9 \mathrm{~Hz}, 2 \mathrm{H})$, $4.97(\mathrm{~d}, J=8.4 \mathrm{~Hz}, 1 \mathrm{H}), 4.54$ (d, $J=7.3 \mathrm{~Hz}, 1 \mathrm{H}), 3.69$ (s, 3H), 3.05 (dd, $J=14.0,5.8 \mathrm{~Hz}, 1 \mathrm{H}), 2.95$ (m, 1H), 1.39 (s, 9H). ${ }^{13} \mathrm{C}$ NMR (151 MHz, $\left.\mathrm{CDCl}_{3}\right) \delta 172.0,154.9,139.6,137.5,135.7,131.3,92.5$, 80.0, 54.2, 52.3, 37.9, 28.3. HRMS (ESI) $m / z$ : Calcd for $\mathrm{C}_{15} \mathrm{H}_{21} \mathrm{INO}_{4} 406.0510$; found 406.0512 . 


\section{$\mathrm{Cbz}$ (Boc)-D-Phe(4-I)-OtBu}

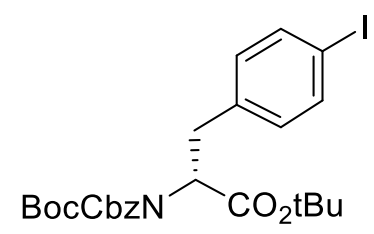

4-Iodo-D-phenylalanine (5 g, $39 \mathrm{mmol})$ and $\mathrm{NaHCO}_{3}(4.9 \mathrm{~g}, 58 \mathrm{mmol}, 1.5 \mathrm{eq})$ were dissolved in $\mathrm{THF} /$ water $(1: 1,100 \mathrm{ml})$ at $0{ }^{\circ} \mathrm{C}$. Benzyl chloroformate $(45.6 \mathrm{mmol}, 6.5 \mathrm{ml}, 1.2 \mathrm{eq})$ in $\mathrm{THF}(50 \mathrm{ml})$ was added and the mixture was stirred for $5 \mathrm{~h}$. The mixture was concentrated under reduced pressure and extracted with diethyl ether $(2 \times 50 \mathrm{ml})$. The aqueous phase was acidified to adjust the $\mathrm{pH}$ to 3 using $1 \mathrm{~N} \mathrm{HCl}$ and extracted with EtOAc $(3 \times 60 \mathrm{ml})$. The combined EtOAc layers were washed with brine $(100 \mathrm{ml})$ and dried over magnesium sulfate. The solvent was evaporated and dried under vacuum, before dissolving in THF $(20 \mathrm{ml})$. Freshly prepared tert-butyl 2,2,2-trichloroacetamide ${ }^{3}(78$ mmol, $14 \mathrm{ml}, 2 \mathrm{eq})$ in diethyl ether $(20 \mathrm{ml})$ was added to the mixture and stirred at room temperature under argon atmosphere, overnight. The mixture was diluted with EtOAc $(100 \mathrm{ml})$ and the organic layers were washed with water $(50 \mathrm{ml}), 10 \%$ sodium bicarbonate $(50 \mathrm{ml})$, and brine $(50 \mathrm{ml})$, before drying over magnesium sulfate. Further purification was performed using column chromatography (25\% EtOAc/Hex) to give Cbz-D-Phe(4-I)-OtBu which was used directly in the next step. The CbzD-Phe(4-I)-OtBu was dissolved in acetonitrile $(30 \mathrm{ml})$ and DMAP (30 mmol, $3.66 \mathrm{~g}, 0.7 \mathrm{eq})$ was added at $0{ }^{\circ} \mathrm{C}$. The mixture was treated with $\mathrm{Boc}_{2} \mathrm{O}(40 \mathrm{mmol}, 8.7 \mathrm{~g}, 1.3 \mathrm{eq})$ and stirred overnight at room temperature. The reaction was diluted with EtOAc $(100 \mathrm{ml})$, washed with saturated ammonium chloride solution $(100 \mathrm{ml})$, and dried over magnesium sulfate. The product was purified using column chromatography (25\% EtOAc/Hex) to give Boc(Cbz)-D-Phe(4-I)-OtBu (15.5g, 75\%) as a transparent oil. ${ }^{1} \mathbf{H}$ NMR $\left(600 \mathrm{MHz}, \mathrm{CDCl}_{3}\right) \delta 7.51(\mathrm{~d}, J=8.3 \mathrm{~Hz}, 2 \mathrm{H}), 7.37-7.28(\mathrm{~m}, 5 \mathrm{H}), 6.84(\mathrm{~d}, J=8.3 \mathrm{~Hz}$, 2H), 5.14 (d, J=12.2 Hz, 1H), 5.08 (d, J=12.2 Hz, 1H), 5.04 (dd, J=10.4, $5.3 \mathrm{~Hz}, 1 \mathrm{H}), 3.31$ (dd, $J=14.1,5.1 \mathrm{~Hz}, 1 \mathrm{H}), 3.11(\mathrm{dd}, J=14.2,10.3 \mathrm{~Hz}, 1 \mathrm{H}), 1.41(\mathrm{~s}, 9 \mathrm{H}), 1.36(\mathrm{~s}, 9 \mathrm{H}) .{ }^{13} \mathrm{C}$ NMR $(151 \mathrm{MHz}$, $\left.\mathrm{CDCl}_{3}\right) \delta 168.7,153.6,151.6,137.5,137.3,131.4,128.5,128.4,128.3,91.8,83.5,82.0,68.6,60.0$, 35.2, 27.9, 27.8. HRMS (ESI) $m / z:[\mathrm{M}+\mathrm{H}]^{+}$Calcd for $\mathrm{C}_{26} \mathrm{H}_{33} \mathrm{INO}_{6} 582.1347$; found 582.1345. 


\section{$\mathrm{Cbz}(\mathrm{Boc})-\mathrm{D}-\mathrm{Phe}(4-\mathrm{neopentylglycolatoboronato)-OtBu}$}

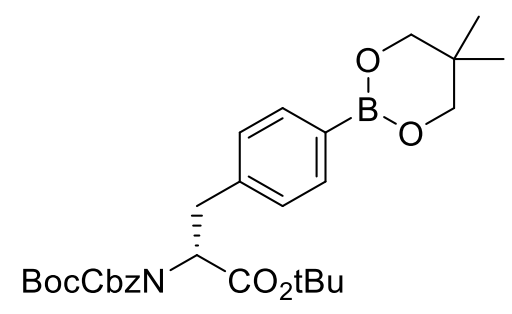

To a solution of $\mathrm{Pd}(\mathrm{dppf}) \mathrm{Cl}_{2} \cdot \mathrm{CH}_{2} \mathrm{Cl}_{2}(45 \mathrm{mg}, 0.055 \mathrm{mmol})$, potassium acetate $(7.5 \mathrm{mmol}, 741 \mathrm{mg})$, and bis(neopentylglycolato)diboron (4.0 mmol, $900 \mathrm{mg}$ ) in DMSO (37 ml), Cbz(Boc)-4-iodo-D-Phe$\mathrm{OtBu}(1.8 \mathrm{mmol}, 1.04 \mathrm{~g})$ was added. The reaction was stirred at $80^{\circ} \mathrm{C}$ for $5 \mathrm{~h}$ under argon atmosphere. Water $(50 \mathrm{ml})$ was added and the resulting mixture was extracted with EtOAc $(3 \times 50 \mathrm{ml})$. The combined organic layers were washed with brine $(100 \mathrm{ml})$ and dried over sodium sulfate. The organic layers were evaporated under reduced pressure and the residue was purified using column chromatography (30\% EtOAc/Hex) to give the product (850 mg, 85\%) as a transparent oil. ${ }^{\mathbf{1}} \mathbf{H}$ NMR $\left(500 \mathrm{MHz}, \mathrm{CDCl}_{3}\right) \delta 7.69(\mathrm{~d}, J=7.8 \mathrm{~Hz}, 2 \mathrm{H}), 7.43-7.25(\mathrm{~m}, 6 \mathrm{H}), 7.12(\mathrm{~d}, J=7.8 \mathrm{~Hz}, 2 \mathrm{H}), 5.19-5.10$ (m, 2H), $5.06(\mathrm{~d}, J=12.2 \mathrm{~Hz}, 1 \mathrm{H}), 3.77(\mathrm{~s}, 3 \mathrm{H}), 3.41$ (dd, $J=14.2,5.1 \mathrm{~Hz}, 1 \mathrm{H}), 3.21$ (dd, $J=14.0,10.3$ $\mathrm{Hz}, 1 \mathrm{H}), 1.43$ (s, 9H), 1.38 (s, 9H), 1.02 (s, 9H). ${ }^{13} \mathbf{C ~ N M R}\left(126 \mathrm{MHz}, \mathrm{CDCl}_{3}\right) \delta 169.0,153.6,151.5$, $140.4,135.3,134.0,128.6,128.4,128.4,128.4,128.2,128.1,83.2,81.7,72.3,68.5,60.3,35.8,31.9$, 27.9, 21.9. HRMS (ESI) $m / z$ : $[\mathrm{M}+\mathrm{H}]^{+}$Calcd for $\mathrm{C}_{31} \mathrm{H}_{43} \mathrm{BNO}_{8}$ 568.3076; found 568.3077. 


\section{Cbz(Boc)-D-Phe(4-boronic acid)-OtBu 7}

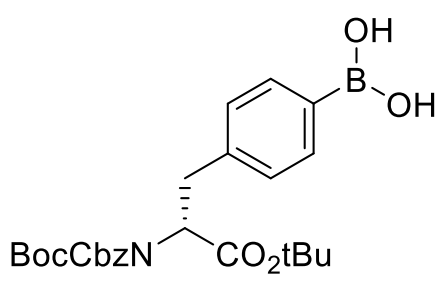

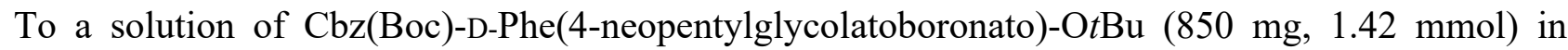
EtOAc $(20 \mathrm{ml})$, water $(40 \mathrm{ml})$ was added. The biphasic reaction was stirred at room temperature for $4 \mathrm{~d}$. The organic layers were washed with water $(4 \times 50 \mathrm{ml})$ and dried over magnesium sulfate. The combined organic layers were evaporated under vacuum. The crude boronic acid 7 was used as a colorless oil in the next step without further purification.

\section{Protected isodityrosine 9}<smiles>CC(C)(C)OC(=O)N[C@@H](Cc1ccc(Oc2cc(CC(NC(=O)OCc3ccccc3)C(=O)OCc3ccccc3)ccc2OCc2ccccc2)cc1)C(=O)OCc1ccccc1</smiles>

Phenylalanine boronic acid derivative $7(0.84 \mathrm{mmol}, 420 \mathrm{mg}, 1.4 \mathrm{eq})$ and DOPA derivative 8 (345 $\mathrm{mg}, 0.6 \mathrm{mmol})$ were added to a solution of $\mathrm{Cu}(\mathrm{OAc})_{2}(109 \mathrm{mg}, 0.6 \mathrm{mmol})$, pyridine $(240 \mu \mathrm{l}, 3 \mathrm{mmol})$, and $4 \AA$ molecular sieves $(1.7 \mathrm{~g})$ in DCM $(20 \mathrm{ml})$. The mixture was stirred at room temperature for $72 \mathrm{~h}$ under an atmosphere of argon. The reaction mixture was filtered and the solid residue washed with DCM $(2 \times 20 \mathrm{ml})$. The combined organic layers were washed with saturated ammonium chloride solution $(100 \mathrm{ml})$ and dried over magnesium sulfate. The solvent was concentrated under reduced pressure and the residue subjected to column chromatography (EtOAc/Hex, 10-40\%) to give the protected isodityrosine 9 (495 $\mathrm{mg}, 80 \%)$ as a white solid. ${ }^{1} \mathbf{H}$ NMR $\left(600 \mathrm{MHz}, \mathrm{CDCl}_{3}\right) \delta 7.33-7.25$ (m, 10H), 7.25-7.20 (m, 3H), 7.20-7.16 (m, 2H), 7.05-6.99 (m, 2H), 6.90-6.83 (m, 2H), 6.83-6.77 
(m, 3H), 5.17-5.13 (m, 2H), $5.11(\mathrm{~m}, 1 \mathrm{H}), 5.05(\mathrm{~d}, J=1.7 \mathrm{~Hz}, 1 \mathrm{H}), 5.00(\mathrm{~s}, 2 \mathrm{H}), 3.38-3.28(\mathrm{~m}, 2 \mathrm{H})$, 3.16-3.07 (m, 2H), $1.40(\mathrm{~s}, 9 \mathrm{H}), 1.35(\mathrm{~s}, 9 \mathrm{H}), 1.32(\mathrm{~s}, 18 \mathrm{H}) .{ }^{13} \mathrm{C}$ NMR $\left(151 \mathrm{MHz}, \mathrm{CDCl}_{3}\right) \delta 170.2$, $169.1,156.8,153.6,151.8,151.6,149.2,145.3,136.9,135.5,135.3,131.6,131.1,130.3,128.4,128.4$, $128.4,128.3,128.3,128.2,128.1,128.1,127.7,127.0,125.6,122.8,118.6,116.9,115.3,83.3,83.0$, 81.7, 71.0, 68.5, 66.9, 60.4, 59.3, 35.0, 34.9, 27.9, 27.8, 27.8, 27.8. HRMS (ESI) $\mathrm{m} / z$ : $[\mathrm{M}+\mathrm{Na}]^{+} \mathrm{Calcd}$ for $\mathrm{C}_{59} \mathrm{H}_{70} \mathrm{~N}_{2} \mathrm{NaO}_{8}$ 1053.4719; found 1053.4720 .

\section{Thr-OtBu.HCl}

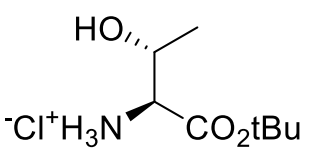

Cbz-Thr-OH (5.0 g, $20 \mathrm{mmol})$ was dissolved in THF $(20 \mathrm{ml})$ and freshly prepared tert-butyl 2,2,2trichloroacetamide $(5.0 \mathrm{~g}, 24 \mathrm{mmol})$ in diethyl ether $(10 \mathrm{ml})$ was added. The resulting mixture was stirred at room temperature under argon overnight. The solvent was evaporated and the compound was purified using flash chromatography to give $\mathrm{Cbz}-\mathrm{Th}$-OtBu which used in the next step without further purification. Cbz-Thr-OtBu (5.25 g, $17 \mathrm{mmol})$ was dissolved in $\mathrm{MeOH}(20 \mathrm{ml})$ and $\mathrm{Pd} / \mathrm{C}(400$ mg) was added. The mixture was stirred under an atmosphere of hydrogen overnight and filtered through celite. The solvent was evaporated and the residue was dissolved in ether $(20 \mathrm{ml})$. The solution was treated with dropwise addition of $1 \mathrm{~N} \mathrm{HCl}$ in diethyl ether $(\sim 16 \mathrm{ml})$ until all the free amine was converted to chloride salt. The precipitated compound was filtered and dried under vacuum to afford threonine tert-butyl ester $(3.4 \mathrm{~g}, 80 \%)$ as a white solid. ${ }^{1} \mathbf{H} \mathbf{~ N M R}\left(600 \mathrm{MHz}, \mathrm{CDCl}_{3}\right)$ $\delta 8.29(\mathrm{~s}, 3 \mathrm{H}), 4.25(\mathrm{~m}, 1 \mathrm{H}), 3.94(\mathrm{~d}, J=6.4 \mathrm{~Hz}, 1 \mathrm{H}), 1.46(\mathrm{~s}, 9 \mathrm{H}), 1.42(\mathrm{~d}, J=6.4 \mathrm{~Hz}, 3 \mathrm{H}) .{ }^{13} \mathbf{C} \mathbf{N M R}$ $\left(151 \mathrm{MHz}, \mathrm{CDCl}_{3}\right) \delta 166.9,84.4,66.3,59.8,27.9,20.7$. HRMS (ESI) $m / z:[\mathrm{M}+\mathrm{H}]^{+}$Calcd for $\mathrm{C}_{8} \mathrm{H}_{18} \mathrm{NO}_{3}$ 176.1281; found 176.1283. 


\section{Isodityrosine-Thr 10}<smiles>CCC(C)(C)OC(=O)N[C@@H](Cc1ccc(Oc2cc(CC(NC(=O)OCc3ccccc3)C(=O)OCc3ccccc3)ccc2OCc2ccccc2)cc1)C(=O)N[C@@H](Cc1ccccc1)C(C)O</smiles>

Isodityrosine derivative 9 (400 mg. $0.43 \mathrm{mmol})$ was treated with a solution of TFA in DCM (60\%, $10 \mathrm{ml}$ ) and stirred for $2 \mathrm{~h}$. The solvent was evaporated and the residue was dissolved in THF (5 ml). $\mathrm{Boc}_{2} \mathrm{O}(94 \mathrm{mg}, 0.43 \mathrm{mmol})$ and $\mathrm{NEt}_{3}(60 \mu \mathrm{l}, 0.43 \mathrm{mmol})$ were added and the resulting mixture was stirred for $4 \mathrm{~h}$. The solvent was evaporated and the residue was dissolved in DMF ( $5 \mathrm{ml}) . \mathrm{NEt}_{3}(1 \mathrm{ml}$, $1.48 \mathrm{mmol}), \mathrm{EDC} \cdot \mathrm{Cl}(74 \mathrm{mg}, 0.48 \mathrm{mmol}), \mathrm{HOBt}(65 \mathrm{mg}, 0.48 \mathrm{mmol})$ and $\mathrm{Thr}-\mathrm{Bu} \cdot \mathrm{HCl}(101 \mathrm{mg}$, $0.48 \mathrm{mmol}$ ) were added and the mixture was stirred overnight. The mixture was added to water (50 $\mathrm{ml})$ and extracted with EtOAc $(3 \times 50 \mathrm{ml})$. The combined organic layers were washed with $1 \mathrm{~N} \mathrm{HCl}$ $(50 \mathrm{ml})$, saturated aqueous sodium bicarbonate $(50 \mathrm{ml})$, brine $(50 \mathrm{ml})$ and dried over magnesium sulfate. The solvent was evaporated and the residue was purified using column chromatography (EtOAc/Hex 25-50\%) to give compound 10 (320 mg, 80\%) as a white solid. ${ }^{1} \mathbf{H}$ NMR (600 MHz, $\left.\mathrm{CDCl}_{3}\right) \delta 7.34-7.15(\mathrm{~m}, 16 \mathrm{H}), 7.11(\mathrm{~d}, J=8.0 \mathrm{~Hz}, 2 \mathrm{H}), 6.86-6.78(\mathrm{~m}, 3 \mathrm{H}), 6.77-6.67(\mathrm{~m}, 2 \mathrm{H}), 5.16-$ $4.96(\mathrm{~m}, 7 \mathrm{H}), 4.52(\mathrm{q}, J=7.0 \mathrm{~Hz}, 1 \mathrm{H}), 4.36(\mathrm{dd}, J=8.7,2.8 \mathrm{~Hz}, 1 \mathrm{H}), 4.19-4.12(\mathrm{~m}, 1 \mathrm{H}), 3.20-2.80(\mathrm{~m}$, 4H), 1.42 (s, 9H), 1.37 (s, 9H), 1.07-0.92 (m, 3H). $\left.{ }^{13} \mathbf{C ~ N M R ~ ( 1 5 1 ~ M H z , ~} \mathrm{CDCl}_{3}\right) \delta 171.7,171.5$, $169.7,157.2,155.9,155.1,149.5,145.3,136.8,135.1,130.4,128.6,128.5,128.4,128.4,128.4,128.1$, $128.1,128.0,127.8,127.0,125.5,122.5,121.6,117.3,115.3,82.4,80.0,71.0,67.1,58.0,54.5,37.5$, 28.3, 28.0, 20.0. HRMS (ESI) $m / z$ : $[\mathrm{M}+\mathrm{H}]^{+}$Calcd. for $\mathrm{C}_{53} \mathrm{H}_{62} \mathrm{~N}_{3} \mathrm{O}_{12}$ 932.4328; found 932.4328. 


\section{Isodityrosine-Thr 11}<smiles>CC(O)[C@@H](NC(=O)[C@H](Cc1ccc(Oc2cc(CC(NC(=O)OC(C)(C)C)C(=O)O)ccc2OCc2ccccc2)cc1)NC(=O)OCc1ccccc1)C(=O)O</smiles>

Peptide 10 (300 mg, $0.32 \mathrm{mmol})$ was dissolved in acetonitrile $(2 \mathrm{ml})$ and a solution of $\mathrm{LiOH}(80 \mathrm{mg}$, $3.2 \mathrm{mmol})$ in water $(0.20 \mathrm{ml})$ was added. The mixture was stirred for $3 \mathrm{~h}$ and acidified using $1 \mathrm{~N} \mathrm{HCl}$ to adjust the $\mathrm{pH}$ to 4 . The compound was extracted with EtOAc $(3 \times 5 \mathrm{ml})$, washed with brine $(10$ $\mathrm{ml}$ ), and dried over magnesium sulfate. The organic layers were evaporated and the residue (268 mg, 99\%) was used as a white solid in the next step without further purification. HRMS (ESI) $m / z$ : $[\mathrm{M}+\mathrm{H}]^{+}$ Calcd for $\mathrm{C}_{46} \mathrm{H}_{54} \mathrm{~N}_{3} \mathrm{O}_{12} 840.3713$; found 840.3712 .

\section{Attempted cyclization of 11}

To a solution of peptide $11(268 \mathrm{mg}, 0.32 \mathrm{mmol})$ in a mixture of DMF/DCM (5 ml, 1:1), DIC (125 $\mu 1,0.8 \mathrm{mmol}), \mathrm{Et}_{3} \mathrm{~N}(51 \mu 1,0.384 \mathrm{mmol})$, and DMAP $(4 \mathrm{mg}, 0.032 \mathrm{mmol})$ were added at $0{ }^{\circ} \mathrm{C}$ under an argon atmosphere. The reaction was warmed to room temperature and stirred for $24 \mathrm{~h}$. The reaction progress was monitored using TLC and mass spectroscopy. However, the cyclized product was not observed. The solvents were evaporated under a stream of nitrogen and the starting material was recovered using HPLC as a white solid. 


\section{Isodityrosine-Thr 12}<smiles>C[C@@H](O)[C@@H](NC(=O)[C@H](Cc1ccc(Oc2cc(CC(NC(=O)OC(C)(C)C)C(=O)O)ccc2OCc2ccccc2)cc1)NC(=O)OCc1ccccc1)C(=O)O</smiles>

Compound 10 (500 mg, $0.54 \mathrm{mmol})$ was dissolved in a solution of TFA in DCM $(60 \%, 10 \mathrm{ml})$. The reaction mixture was stirred for $2 \mathrm{~h}$ then the solvent was evaporated under reduced pressure. The compound was dissolved in THF $(10 \mathrm{ml})$ then $\mathrm{Boc}_{2} \mathrm{O}(130 \mathrm{mg}, 0.6 \mathrm{mmol})$ and $\mathrm{NEt}_{3}(147 \mu \mathrm{l}, 1.1$ mmol) were added. The solvent was evaporated and the residue was dissolved in EtOAc $(20 \mathrm{ml})$. The organic layers were washed with aqueous $1 \mathrm{~N} \mathrm{HCl}$ solution $(20 \mathrm{ml})$, brine $(20 \mathrm{ml})$, and dried over magnesium sulfate. The solvent was evaporated and the residue was purified using column chromatography (MeOH/DCM, 5-10\%) to give compound 12 (425 mg, 90\%) as a white solid. ${ }^{1} \mathbf{H}$ NMR $\left(400 \mathrm{MHz}, \mathrm{CDCl}_{3}\right) \delta 7.40-7.26(\mathrm{~m}, 14 \mathrm{H}), 7.17(\mathrm{~d}, J=8.1 \mathrm{~Hz}, 2 \mathrm{H}), 7.0-6.87(\mathrm{~m}, 3 \mathrm{H}), 6.80-6.65$ (m, 3H), $5.84(\mathrm{t}, J=6.4 \mathrm{~Hz}, 1 \mathrm{H}), 5.21-5.03(\mathrm{~m}, 6 \mathrm{H}), 4.67-4.41(\mathrm{~m}, 3 \mathrm{H}), 4.36-4.18(\mathrm{~m}, 2 \mathrm{H}), 3.07-$ $2.64(\mathrm{~m}, 4 \mathrm{H}), 1.35(\mathrm{~s}, 9 \mathrm{H}), 1.28(\mathrm{~s}, 9 \mathrm{H}), 1.05(\mathrm{~d}, J=6.4 \mathrm{~Hz}, 3 \mathrm{H}) .{ }^{13} \mathbf{C} \mathbf{N M R}\left(101 \mathrm{MHz}, \mathrm{CDCl}_{3}\right) \delta$ $172.9,172.6,172.1,157.1,156.4,155.4,149.4,145.6,136.8,135.0,130.7,130.6,129.4,128.6,128.5$, $128.4,128.2,128.0,127.8,127.1,125.4,121.9,118.2,117.6,115.3,80.5,71.0,67.7,67.3,57.4,56.3$, 54.7, 37.4, 28.2, 19.3. HRMS (ESI) $m / z$ : $[\mathrm{M}+\mathrm{H}]^{+}$Calcd for $\mathrm{C}_{49} \mathrm{H}_{54} \mathrm{~N}_{3} \mathrm{O}_{12}$ 876.3702; found 876.3703.

\section{Fmoc-D-Leu-Leu-Ile-OH}<smiles>CCC(C)[C@H](NC(=O)[C@H](CC(C)C)NC(=O)[C@H](CC(C)C)NC(F)F)C(=O)O</smiles> 
Fmoc-Ile-OH (1.4 g, 2 mmol) was loaded on 2-chlorotrityl chloride resin (2-CTC) (0.5 mmol, 615 mg) using DIPEA $(354 \mu 1,2 \mathrm{mmol})$ in DCM $(10 \mathrm{ml})$. The resin was shaken for $5 \mathrm{~h}$, before washing with DCM $(\times 5)$, DMF $(\times 5)$, and DCM $(\times 5)$. The unreacted resin was capped with $\mathrm{MeOH}(1 \mathrm{ml})$ and DIPEA (354 $\mu \mathrm{l}, 2 \mathrm{mmol})$ for $1 \mathrm{~h}$. The compound was filtered and washed with DCM $(\times 5)$ and DMF $(\times 5)$. The resin was treated with a solution of $20 \%$ piperidine in DMF $(10 \mathrm{ml})$ for $5 \mathrm{~min}$ to deprotect Fmoc group. Fmoc-Leu-OH (1.4 g, 2 mmol) was coupled to the isoleucine loaded resin using HATU and DIPEA (354 $\mu \mathrm{l}, 2 \mathrm{mmol})$ and the resin was shaken for to $1 \mathrm{~h}$. The conventional deprotection and Fmoc amino acid coupling was continued to synthesis Fmoc-DLeu-Leu-Ile supported to the CTC resin. The peptide was cleaved from the resin using a solution of 5\% TFA in $\operatorname{DCM}(2 \times 10 \mathrm{ml})$ and the filtrate solvent was evaporated under a stream of nitrogen. The peptide was purified with HPLC to afford Fmoc-DLeu-Leu-Ile-OH (203 mg, 70\%) as a white solid. ${ }^{\mathbf{1}} \mathbf{H}$ NMR (400

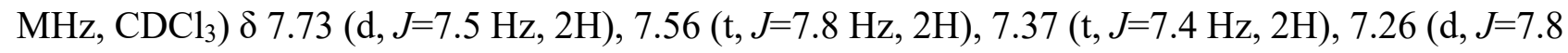
$\mathrm{Hz}, 2 \mathrm{H}), 5.85(\mathrm{~d}, J=8.1 \mathrm{~Hz}, 1 \mathrm{H}), 4.64-4.47(\mathrm{~m}, 2 \mathrm{H}), 4.38(\mathrm{~m}, 1 \mathrm{H}), 4.33-4.22(\mathrm{~m}, 2 \mathrm{H}), 4.17(\mathrm{t}, J=7.0$ $\mathrm{Hz}, 1 \mathrm{H}), 2.03-1.83(\mathrm{~m}, 1 \mathrm{H}), 1.70-1.39(\mathrm{~m}, 6 \mathrm{H}), 1.28-1.07(\mathrm{~m}, 1 \mathrm{H}), 1.00-0.76(\mathrm{~m}, 16 \mathrm{H}) .{ }^{13} \mathbf{C}$ NMR $\left(101 \mathrm{MHz}, \mathrm{CDCl}_{3}\right) \delta 174.0,173.3,172.3,156.4,143.8,143.6,141.3,141.2,127.7,127.1,125.0$, 120.0, 67.2, 56.9, 53.7, 47.0, 41.4, 40.4, 30.9, 24.9, 24.7, 22.8, 22.8, 21.9, 15.3, 11.4. HRMS (ESI) $m / z:[\mathrm{M}+\mathrm{H}]^{+}$Calcd for $\mathrm{C}_{33} \mathrm{H}_{46} \mathrm{~N}_{3} \mathrm{O}_{6} 580.3381$; found 580.3382 .

\section{D-Leu-Leu-Ile-OtBu 13}

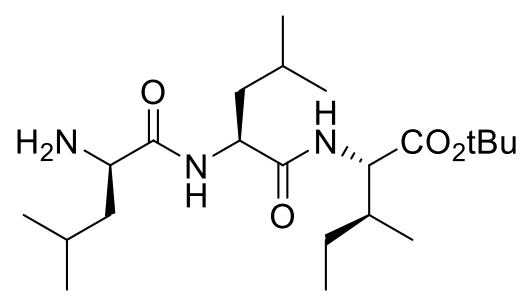

Fmoc-D-Leu-Leu-Ile-OH (200 mg, $0.345 \mathrm{mmol})$ was dissolved in THF (5 ml) and freshly prepared tert-butyl 2,2,2-trichloroacetamide $(218 \mathrm{mg}, 1 \mathrm{mmol})$ in diethyl ether $(5 \mathrm{ml})$ was added to the reaction vessel. The reaction was stirred overnight and solvent was evaporated. The residue was purified using 
column chromatography (EtOAc/Hex, 30-65\%) to provide Fmoc-DLeu-Leu-Ile-OtBu in quantitative yield (216 mg, 99\%) as a white solid. ${ }^{1} \mathbf{H}$ NMR (400 MHz, $\left.\mathrm{CDCl}_{3}\right) \delta 7.74(\mathrm{~d}, J=7.6 \mathrm{~Hz}, 2 \mathrm{H}), 7.60$ $7.54(\mathrm{~m}, 2 \mathrm{H}), 7.37(\mathrm{t}, J=7.5 \mathrm{~Hz}, 2 \mathrm{H}), 7.28(\mathrm{t}, J=7.3 \mathrm{~Hz}, 2 \mathrm{H}), 7.10(\mathrm{~d}, J=8.3 \mathrm{~Hz}, 1 \mathrm{H}), 6.94(\mathrm{~d}, J=8.7$ $\mathrm{Hz}, 1 \mathrm{H}), 5.71(\mathrm{~d}, J=8.5 \mathrm{~Hz}, 1 \mathrm{H}), 4.56(\mathrm{~m}, 1 \mathrm{H}), 4.42(\mathrm{~m}, 2 \mathrm{H}), 4.36-4.27(\mathrm{~m}, 2 \mathrm{H}), 4.16(\mathrm{~m}, 1 \mathrm{H}), 1.82$ (ddt, $J=9.4,7.0,4.8 \mathrm{~Hz}, 1 \mathrm{H}), 1.65(\mathrm{~m}, 6 \mathrm{H}), 1.57(\mathrm{~m}, 3 \mathrm{H}), 1.42(\mathrm{~s}, 9 \mathrm{H}), 1.15(\mathrm{~m}, 1 \mathrm{H}), 1.01-0.80(\mathrm{~m}$, 15H). ${ }^{13} \mathrm{C}$ NMR $\left(151 \mathrm{MHz}, \mathrm{CDCl}_{3}\right) \delta 172.4,172.3,171.3,170.5,156.1,143.8,143.7,141.2,127.7$, $127.0,125.0,125.0,119.9,81.8,67.1,56.8,56.7,53.6,51.7,51.5,47.1,41.8,41.7,41.3,40.9,37.9$, 28.0, 25.3, 25.2, 24.7, 24.6, 22.9, 22.8, 22.0, 15.4, 15.3, 11.7, 11.6. HRMS (ESI) $\mathrm{m} / z$ [M+H] $]^{+}$Calcd for $\mathrm{C}_{37} \mathrm{H}_{54} \mathrm{~N}_{3} \mathrm{O}_{6}$ 636.4007; found 636.4009. Fmoc-DLeu-Leu-Ile-OtBu was treated with $20 \%$ piperidine in DMF $(10 \mathrm{ml})$ and the resulting mixture was stirred for $5 \mathrm{~min}$. The mixture was acidified using $1 \mathrm{~N} \mathrm{HCl}$ till the $\mathrm{PH}$ adjusted to 3, before washing with diethyl ether. The aqueous phase was basified using $0.5 \mathrm{~N}$ sodium hydroxide and $\mathrm{pH}$ was adjusted to 9 . The aqueous phase was extracted with EtOAc $(3 \times 20 \mathrm{ml})$ and combined organic layers were washed with brine $(20 \mathrm{ml})$ and dried over magnesium sulfate. The solvent was evaporated under reduced pressure and the product $\mathbf{1 3}$ was used as a yellow oil in the next step without further purification.

\section{Macrocycle 14}

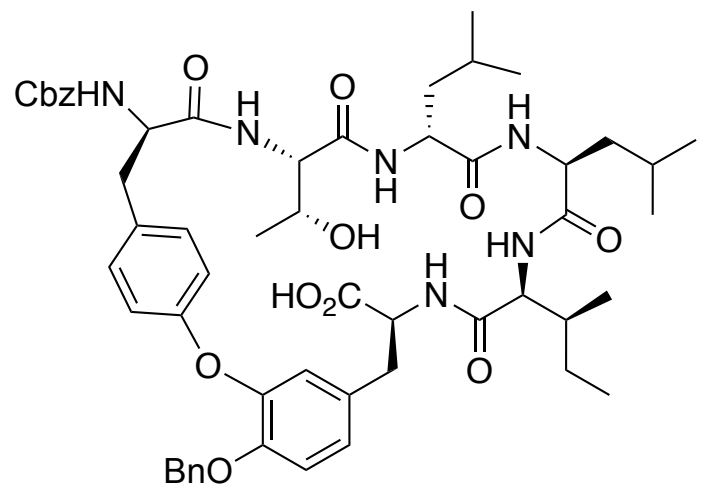

Peptide 12 (100 mg, 0.114 mmol), peptide D-Leu-Leu-Ile-OtBu 13 (52 mg, 0.125 mmol), EDC.Cl (20 $\mathrm{mg}, 0.125 \mathrm{mmol}), \mathrm{HOBt}(16 \mathrm{mg}, 0.125 \mathrm{mmol})$, and NEt $3(17 \mu \mathrm{l}, 0.125 \mathrm{mmol})$ were dissolved in DMF $(3 \mathrm{ml})$. The mixture was stirred overnight then water $(5 \mathrm{ml})$ was added to the mixture. The resulting 
suspension was extracted with EtOAc $(3 \times 5 \mathrm{ml})$ and the combined organic layers were washed with $1 \mathrm{~N} \mathrm{HCl}(10 \mathrm{ml})$, saturated sodium bicarbonate $(10 \mathrm{ml})$, brine $(10 \mathrm{ml})$, and dried over magnesium sulfate. The solvent was evaporated and the residue (125 mg, 84\%) was dissolved in a solution of TFA in DCM $(65 \%, 5 \mathrm{ml})$. The mixture was stirred for $2 \mathrm{~h}$ and solvent was evaporated under reduced pressure. Further drying was done under high vacuum. The residue (100 mg, 98\%) was dissolved in a mixture of DCM/DMF (1:1, $40 \mathrm{ml}, 0.003 \mathrm{M})$. HATU (43 mg, $0.114 \mathrm{mmol})$, HOAt $(114 \mu 1,1 \mathrm{M}$ in $\mathrm{DMF}$ ), and $\mathrm{NEt}_{3}(51 \mu \mathrm{l}, 375 \mathrm{mmol})$ were subsequently added. The mixture was stirred for $20 \mathrm{~h}$ and water $(50 \mathrm{ml})$ was added to the mixture. The aqueous phase was extracted with DCM $(3 \times 20 \mathrm{ml})$. The combined organic layers were washed with $1 \mathrm{~N} \mathrm{HCl}(50 \mathrm{ml})$, saturated sodium bicarbonate (50 $\mathrm{ml})$, brine $(50 \mathrm{ml})$, and dried over magnesium sulfate. The solvent was evaporated under reduced pressure and the residue $(60 \mathrm{mg}, 60 \%)$ was re-dissolved in dioxane $(3 \mathrm{ml})$. $\mathrm{LiOH}(27 \mathrm{mg}, 1.14 \mathrm{mmol})$ in water $(100 \mu \mathrm{l})$ was added to the mixture and stirred for $3 \mathrm{~h}$. The reaction mixture was acidified using $1 \mathrm{~N} \mathrm{HCl}$ to adjust the $\mathrm{pH}$ to 3 and extracted EtOAc $(3 \times 5 \mathrm{ml})$. The combined organic layers were dried over magnesium sulfate and solvent evaporated under reduced pressure. The compound was purified using HPLC to afford the macrocycle $\mathbf{1 4}$ (51 mg, 94\%) as a white solid. ${ }^{\mathbf{1}} \mathbf{H}$ NMR (600 $\left.\mathrm{MHz} \mathrm{CDCl}_{3}\right) \delta 7.46(\mathrm{~d}, J=6.3 \mathrm{~Hz}, 1 \mathrm{H}), 7.39-7.25(\mathrm{~m}, 15 \mathrm{H}), 7.20(\mathrm{~d}, J=8.2 \mathrm{~Hz}, 2 \mathrm{H}), 7.12-7.07$ (m, 2H), 7.04-6.99 (m, 2H), $6.96(\mathrm{~d}, J=8.1 \mathrm{~Hz}, 2 \mathrm{H}), 6.73(\mathrm{~d}, J=8.3 \mathrm{~Hz}, 1 \mathrm{H}), 6.55-6.46(\mathrm{~m}, 3 \mathrm{H}), 6.37$ (d, $J=8.4 \mathrm{~Hz}, 1 \mathrm{H}), 5.50(\mathrm{~d}, J=6.5 \mathrm{~Hz}, 1 \mathrm{H}), 5.19-5.13(\mathrm{~m}, 3 \mathrm{H}), 5.10(\mathrm{~s}, 2 \mathrm{H}), 5.01-4.96(\mathrm{~m}, 3 \mathrm{H}), 4.60(\mathrm{~m}$, $1 \mathrm{H}), 4.53(\mathrm{~m}, 1 \mathrm{H}), 4.41-4.33(\mathrm{~m}, 2 \mathrm{H}), 4.31(\mathrm{~d}, J=8.9 \mathrm{~Hz}, 2 \mathrm{H}), 4.25-4.16(\mathrm{~m}, 2 \mathrm{H}), 3.14(\mathrm{~m}, 1 \mathrm{H})$, 2.94-2.84 (m, 2H), $2.69(\mathrm{dd}, J=13.6,9.4 \mathrm{~Hz}, 1 \mathrm{H}), 1.78(\mathrm{~m}, 3 \mathrm{H}), 1.65-1.53(\mathrm{~m}, 4 \mathrm{H}), 1.48(\mathrm{~m}, 1 \mathrm{H})$, $1.43(\mathrm{~m}, 1 \mathrm{H}), 1.09$ (ddd, $J=13.4,9.0,7.1 \mathrm{~Hz}, 2 \mathrm{H}), 0.93$ (d, J=6.6 Hz, 3H), 0.91-0.87 (m, 8H), 0.86$0.79(\mathrm{~m}, 18 \mathrm{H}) .{ }^{13} \mathbf{C}$ NMR $\left(151 \mathrm{MHz}, \mathrm{CDCl}_{3}\right) \delta 172.5,172.1,171.7,171.0,170.8,157.0,156.2,149.3$, $146.9,137.0,135.8,134.7,130.4,129.8,129.3,128.6,128.5,128.4,128.4,128.3,128.3,128.0,127.8$, $127.2,125.1,120.5,119.1,115.2,71.3,67.1,67.1,64.5,58.4,58.0,57.3,54.1,53.1,52.3,41.0,39.4$, 38.3, 37.0, 24.9, 24.8, 24.6, 23.2, 22.6, 22.3, 21.0, 20.0, 15.3, 10.9. HRMS (ESI) $m / z:[\mathrm{M}+\mathrm{H}]^{+}$Calcd for $\mathrm{C}_{55} \mathrm{H}_{71} \mathrm{~N}_{6} \mathrm{O}_{12}$ 1007.5124; found 1007.5125. 


\section{Attempted cyclization of 14}

To a solution of peptide $14(51 \mathrm{mg}, 0.05 \mathrm{mmol})$ in a mixture of DMF/DCM (1 ml, 1:1), DIC (20 $\mu 1$, $0.126 \mathrm{mmol}), \mathrm{Et}_{3} \mathrm{~N}(8.3 \mu \mathrm{l}, 0.06 \mathrm{mmol})$, and DMAP $(1 \mathrm{mg}, 0.008 \mathrm{mmol})$ were added at $0{ }^{\circ} \mathrm{C}$ under an argon atmosphere. The reaction was warmed up to room temperature and stirred for $24 \mathrm{~h}$. The reaction progress was monitored using TLC and mass spectroscopy. However, the cyclized product was not observed. The solvents were evaporated under a stream of nitrogen and the starting material was recovered using HPLC.

\section{Ac-Leu-D-Ala-OMe}

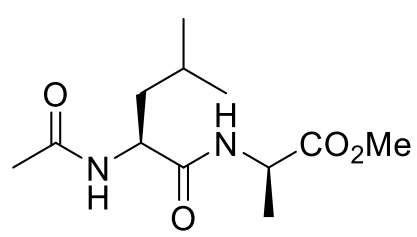

To a mixture of Ac-Leu-OH (2 g, $11.5 \mathrm{mmol})$, EDC. Cl (2.1 g, $13.8 \mathrm{mmol})$, and HOBt (1.6 g, 13.8) in DMF (20 ml), D-Ala-Me.HCl (1.9 g, 13.8) and $\mathrm{NEt}_{3}(1.8 \mathrm{ml}, 13.8 \mathrm{mmol})$ were added and the mixture was stirred overnight. Water $(40 \mathrm{ml})$ was added then the mixture was extracted with EtOAc $(3 \times 50 \mathrm{ml})$. The combined organic layers were washed with saturated sodium bicarbonate $(100 \mathrm{ml})$, $1 \mathrm{~N} \mathrm{HCl}(100 \mathrm{ml})$, brine $(100 \mathrm{ml})$, and dried over magnesium sulfate. The solvent was evaporated and the residue was subjected to the column chromatography $(25 \%$ EtOAc/Hex $)$ to give the product peptide $(2.4 \mathrm{~g}, 80 \%)$ as a white solid. ${ }^{1} \mathbf{H}$ NMR $\left(600 \mathrm{MHz}, \mathrm{CDCl}_{3}\right) \delta 7.27(\mathrm{~d}, J=7.5 \mathrm{~Hz}, 1 \mathrm{H}), 6.77(\mathrm{~d}$, $J=8.4 \mathrm{~Hz}, 1 \mathrm{H}), 4.53(\mathrm{~m}, 1 \mathrm{H}), 4.45(\mathrm{~m}, 1 \mathrm{H}), 3.65(\mathrm{~s}, 3 \mathrm{H}), 1.93(\mathrm{~s}, 3 \mathrm{H}), 1.58(\mathrm{~m}, 2 \mathrm{H}), 1.50(\mathrm{~m}, 1 \mathrm{H})$, $1.34(\mathrm{~d}, J=7.2 \mathrm{~Hz}, 3 \mathrm{H}), 0.86(\mathrm{~m}, 6 \mathrm{H}) .{ }^{13} \mathbf{C}$ NMR $\left(151 \mathrm{MHz}, \mathrm{CDCl}_{3}\right) \delta 173.1,172.2,170.4,52.3,51.4$, 48.0, 41.1, 24.7, 22.9, 22.8, 22.1, 17.8. HRMS (ESI) $m / z$ : $[\mathrm{M}+\mathrm{H}]^{+}$Calcd for $\mathrm{C}_{12} \mathrm{H}_{23} \mathrm{~N}_{2} \mathrm{O}_{4} 259.1652$; found 259.1654 . 


\section{D-Phe(4-I)-OMe.HCl}<smiles>CC(=O)[C@H](N)Cc1ccc(I)cc1</smiles>

Boc-4-iodo-D-Phe-OMe (2 g, $5 \mathrm{mmol})$ was dissolved in TFA/DCM (3:7, $40 \mathrm{ml})$ and stirred for $1 \mathrm{~h}$. The solvent was evaporated and the residue was dissolved in diethyl ether. A solution of $1 \mathrm{~N} \mathrm{HCl}$ in diethyl ether was added to precipitate the product as a white $\mathrm{HCl}$ salt $(1.5 \mathrm{~g}, 99 \%) .{ }^{1} \mathbf{H}$ NMR $(600$ MHz, DMSO-d $\left.d_{6}\right) \delta 8.85-8.65(\mathrm{~m}, 3 \mathrm{H}), 7.71-7.59(\mathrm{~m}, 2 \mathrm{H}), 7.03(\mathrm{~d}, J=7.8 \mathrm{~Hz}, 2 \mathrm{H}), 4.19(\mathrm{~m}, 1 \mathrm{H}), 3.63$ (s, 3H), $3.15(\mathrm{~m}, 1 \mathrm{H}), 3.05(\mathrm{~m}, 1 \mathrm{H}) .{ }^{13} \mathbf{C}$ NMR (151 MHz, DMSO-d6) $\delta 169.6,169.6,137.7,135.0$, 132.3, 94.0, 53.4, 53.1, 35.5. HRMS (ESI) $m / z$ : $[\mathrm{M}+\mathrm{H}]^{+}$Calcd for $\mathrm{C}_{10} \mathrm{H}_{13} \mathrm{INO}_{2}$ 305.9985; found 305.9988.

\section{Ac-Leu-D-Ala-D-Phe(I)-OMe}<smiles>CC(=O)N[C@@H](CC(C)C)C(=O)N[C@@H](C)C(=O)N[C@@H](Cc1ccc(I)cc1)C(C)=O</smiles>

To a solution of Ac-Leu-D-Ala-OMe $(2.6 \mathrm{~g}, 10 \mathrm{mmol})$ in dioxane $(20 \mathrm{ml})$, lithium hydroxide $(620$ $\mathrm{mg}, 30 \mathrm{mmol})$ in water $(2 \mathrm{ml})$ was added dropwise. The mixture was stirred for $3 \mathrm{~h}$ and the $\mathrm{pH}$ was adjusted to 3 using $1 \mathrm{~N} \mathrm{HCl}$. The mixture was extracted with EtOAc $(3 \times 50 \mathrm{ml})$ and the combined organic layers were washed with brine $(100 \mathrm{ml})$. The organic layers were dried over magnesium sulfate and evaporated under reduced pressure. The residue was dried under reduced pressure and the residue was dissolved in DMF (20 ml). EDC.Cl (1.55 g, $10 \mathrm{mmol})$, HOBt (1.2 g, $10 \mathrm{mmol}^{2}, \mathrm{NEt}_{3}$ $(0.74 \mathrm{ml}, 10 \mathrm{mmol})$, and 4-iodo-D-Phe-OMe.HCl (3.4 g, $10 \mathrm{mmol})$ were added subsequently and the 
reaction mixture was stirred at room temperature overnight. Water (50 ml) was added to the reaction mixture and extracted with EtOAc $(3 \times 50 \mathrm{ml})$. The combined organic layers were washed with $1 \mathrm{~N}$ $\mathrm{HCl}(100 \mathrm{ml})$, saturated sodium bicarbonate $(100 \mathrm{ml})$, brine $(100 \mathrm{ml})$, and dried over magnesium sulfate. The solvent was evaporated under reduced pressure and residue was purified using column chromatography (40\% EtOAc/Hex) to give the title compound $(4.25 \mathrm{~g}, 80 \%)$ as a white solid. ${ }^{1} \mathbf{H}$ NMR $\left(500 \mathrm{MHz}, \mathrm{CDCl}_{3}\right) \delta 7.61(\mathrm{~d}, J=8.3 \mathrm{~Hz}, 2 \mathrm{H}), 6.90(\mathrm{~d}, J=8.3 \mathrm{~Hz}, 2 \mathrm{H}), 6.77(\mathrm{~s}, 1 \mathrm{H}), 6.12(\mathrm{~s}, 1 \mathrm{H})$, $4.76(\mathrm{~m}, 1 \mathrm{H}), 4.49-4.36(\mathrm{~m}, 2 \mathrm{H}), 3.70(\mathrm{~s}, 3 \mathrm{H}), 3.10(\mathrm{dd}, J=13.9,5.7 \mathrm{~Hz}, 1 \mathrm{H}), 3.00$ (dd, $J=13.9,7.1$ $\mathrm{Hz}, 1 \mathrm{H}), 1.97(\mathrm{~s}, 3 \mathrm{H}), 1.83(\mathrm{~d}, J=8.1 \mathrm{~Hz}, 1 \mathrm{H}), 1.72-1.60(\mathrm{~m}, 2 \mathrm{H}), 1.52(\mathrm{~m}, 1 \mathrm{H}), 1.33$ (d, J=7.2 Hz, 3H), $0.96(\mathrm{~d}, J=6.2 \mathrm{~Hz}, 3 \mathrm{H}), 0.93(\mathrm{~d}, J=6.2 \mathrm{~Hz}, 3 \mathrm{H}) .{ }^{13} \mathbf{C} \mathbf{N M R}\left(101 \mathrm{MHz}, \mathrm{CDCl}_{3}\right) \delta 171.9,171.7$, $171.6,170.9,137.6,135.8,131.3,92.5,53.2,52.4,51.9,49.0,40.5,37.2,24.7,23.0,22.8,22.2,18.0$. HRMS (ESI) $m / z:[\mathrm{M}+\mathrm{H}]^{+}$Calcd for $\mathrm{C}_{21} \mathrm{H}_{31} \mathrm{IN}_{3} \mathrm{O}_{5}$ 532.1303; found 532.1305.

\section{Ac-Leu-D-Ala-D-Phe(Bpin)-OMe}

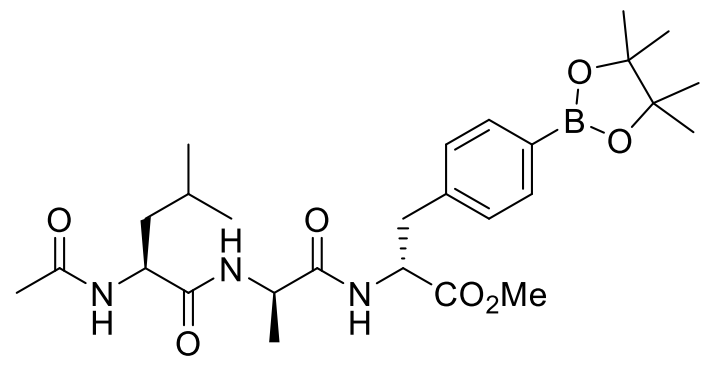

To an oven dried 2-necked round bottom flask containing Ac-Leu-D-Ala-D-Phe(I)-OMe (2.0 mmol, $1.1 \mathrm{~g})$, potassium acetate $(6 \mathrm{mmol}, 726 \mathrm{mg})$, bis(pinacolato)diboron $(3.4 \mathrm{mmol}, 860 \mathrm{mg})$, and [1,1'bis(diphenylphosphino)-ferrocene]palladium(II) dichloride (0.113 mmol, $92 \mathrm{mg}$ ) were added. Dry dimethylsulfoxide $(15 \mathrm{ml})$ was added and the mixture was heated using an oil bath at $80{ }^{\circ} \mathrm{C}$ for $10 \mathrm{~h}$. The mixture was cooled to room temperature and water $(20 \mathrm{ml})$ was added to the mixture and extracted with EtOAc $(3 \times 50 \mathrm{ml})$. The combined organic layers were washed with saturated ammonium chloride $(20 \mathrm{ml})$, brine $(20 \mathrm{ml})$, and dried over magnesium sulfate. The solvent was evaporated under reduced pressure and the residue was purified using column chromatography 
(EtOAc/Hex, 10-40\%) to give the title compound (1.0 g, 95\%) as a white solid. ${ }^{1} \mathbf{H}$ NMR (600 MHz, $\left.\mathrm{CDCl}_{3}\right) \delta 7.69(\mathrm{~d}, J=8.0 \mathrm{~Hz}, 2 \mathrm{H}), 7.11(\mathrm{~d}, J=8.0 \mathrm{~Hz}, 2 \mathrm{H}), 6.90(\mathrm{~d}, J=7.6 \mathrm{~Hz}, 1 \mathrm{H}), 6.83(\mathrm{~d}, J=7.8 \mathrm{~Hz}$, 1H), $6.23(\mathrm{~d}, J=8.0 \mathrm{~Hz}, 1 \mathrm{H}), 4.76(\mathrm{~m}, 1 \mathrm{H}), 4.45-4.35(\mathrm{~m}, 2 \mathrm{H}), 3.65(\mathrm{~s}, 3 \mathrm{H}), 3.12(\mathrm{dd}, J=13.9,5.9 \mathrm{~Hz}$, 1H), $3.04(\mathrm{dd}, J=13.9,7.0 \mathrm{~Hz}, 1 \mathrm{H}), 1.92(\mathrm{~s}, 3 \mathrm{H}), 1.66-1.55(\mathrm{~m}, 2 \mathrm{H}), 1.46(\mathrm{~m}, 1 \mathrm{H}), 1.30(\mathrm{~s}, 6 \mathrm{H}), 1.28$ (d, $J=7.0 \mathrm{~Hz}, 3 \mathrm{H}), 1.23(\mathrm{~s}, 6 \mathrm{H}), 0.91(\mathrm{~d}, J=6.4 \mathrm{~Hz}, 3 \mathrm{H}), 0.88(\mathrm{~d}, J=6.3 \mathrm{~Hz}, 3 \mathrm{H}) .{ }^{13} \mathbf{C}$ NMR $(151 \mathrm{MHz}$, $\left.\mathrm{CDCl}_{3}\right) \delta 172.0,171.7,170.9,139.3,135.0,128.6,83.8,83.5,75.0,53.3,52.3,51.7,48.9,40.8,40.5$, 37.9, 25.0, 24.8, 24.7, 23.0, 22.8, 22.1, 17.8. HRMS (ESI) $m / z$ : $[\mathrm{M}+\mathrm{H}]^{+}$Calcd for $\mathrm{C}_{27} \mathrm{H}_{43} \mathrm{BN}_{3} \mathrm{O}_{7}$ 532.3189; found 532.3192.

\section{Ac-Leu-D-Ala-D-Phe(Bpin)-OH 16}<smiles>CC(C)CC(NC(C)C)C(=O)N[C@@H](C)C(=O)N[C@@H](Cc1ccc(Br)cc1)C(=O)O</smiles>

Ac-Leu-D-Ala-D-Phe(Bpin)-OMe $(1.0 \mathrm{~g}, 1.9 \mathrm{mmol})$ was dissolved in dioxane $(10 \mathrm{ml})$ and lithium hydroxide $(228 \mathrm{mg}, 9.5 \mathrm{mmol})$ in water $(1 \mathrm{ml})$ was added at $0{ }^{\circ} \mathrm{C}$. The mixture was gradually warmed up to room temperature and stirred for $4 \mathrm{~h}$. Water $(20 \mathrm{ml})$ was added to the reaction mixture and $\mathrm{pH}$ was adjusted to 4 using $1 \mathrm{~N} \mathrm{HCl}$, before extracting with EtOAc $(3 \times 20 \mathrm{ml})$. The combined organic layers were washed with brine $(50 \mathrm{ml})$, dried over magnesium sulfate, and the solvent was evaporated under reduced pressure. Further drying was done using high vacuum and the title compound 16 which was used as a white solid in the next step without further purification. HRMS (ESI) $m / z$ : $[\mathrm{M}+\mathrm{H}]^{+}$ Calcd for $\mathrm{C}_{26} \mathrm{H}_{41} \mathrm{BN}_{3} \mathrm{O}_{7}$ 518.3032; found 518.3034. 


\section{Fmoc Solid-Phase Synthesis (Fmoc-SPPS)}

Fmoc-SPPS procedures were undertaken using 2-chlorotrityl chloride (CTC) resin.

\section{General deprotection and coupling protocols}

The resin was treated with a solution of $20 \mathrm{vol} \%$ piperidine and $0.1 \mathrm{vol} \%$ oxyma in DMF $(2 \times 5 \mathrm{~min})$. The resin was then washed with DMF $(\times 5)$, DCM $(\times 5)$ and DMF $(\times 5)$. The resin was next treated with a solution of the required Fmoc-protected amino acid (3 eq), HATU (3 eq) and DIPEA (3 eq) in DMF and the mixture was shaken gently for $2 \mathrm{~h}$ at room temperature. The coupling solution was discharged and the resin washed with DMF $(\times 5), \operatorname{DCM}(\times 5)$ and DMF $(\times 5)$.

\section{Linear depsipeptide 20}<smiles>CC[C@@H](C)[C@H](NC(=O)[C@H](CC(C)C)NC(=O)[C@H](CC(C)C)NC(=O)[C@@H](NC(=O)[C@H](Cc1ccc(Cc2ccccc2)cc1)NC(=O)[C@H](C)NC(=O)[C@H](CC(C)C)NC(C)=O)[C@H](C)OC(=O)[C@H](N)Cc1ccc(OCc2ccccc2)c(OCc2ccccc2)c1)C(=O)O</smiles>

In a fitted syringe, 2-chlorotrityl chloride (CTC) resin (300 mg, $\left.1.3 \mathrm{mmol} \mathrm{g}{ }^{-1}\right)$ was swollen in DCM for $30 \mathrm{~min}$. Fmoc-Ile-OH (282 mg, $0.8 \mathrm{mmol}, 2 \mathrm{eq})$ and DIPEA (150 $\mu \mathrm{l}, 0.8 \mathrm{mmol}$, 2eq) were dissolved in DCM and transferred to the syringe. The mixture was shaken for $8 \mathrm{~h}$ and washed with DCM (× 3). The unreacted CTC was capped using a freshly prepared solution of DCM/MeOH/DIPEA (17:2:1). After $1 \mathrm{~h}$, the resin was washed with DCM $(\times 5)$ and DMF $(\times 3)$. Fmoc deprotection was performed using a solution of $20 \mathrm{vol} \%$ piperidine and $0.1 \mathrm{vol} \%$ oxyma in DMF (2 $\times 5 \mathrm{~min})$ then washed with $\mathrm{DMF}(\times 5), \mathrm{DCM}(\times 5)$ and $\mathrm{DMF}(\times 5)$. The linear peptide was elongated using standard HATU coupling conditions, incorporating the amino acids Fmoc-L-Leu-OH, Fmoc-D- 
Leu-OH, and Fmoc-Thr-OH to afford resin-bound peptide 15. Fmoc deprotection of resin-bound peptide 15 was performed using a solution of 20 vol\% piperidine and 0.1 vol\% oxyma in DMF $(2 \times$ $5 \mathrm{~min})$ then washed with DMF $(\times 5), \mathrm{DCM}(\mathrm{x} 5)$ and $\mathrm{DMF}(\times 5)$. A solution of Ac-Leu-D-Ala-DPhe(pinacolatoboron)-OH 16 (310 mg , $0.61 \mathrm{mmol})$, HATU (1.5 mmol), and DIPEA (2 mmol) was then transferred to the resin-bound peptide $\mathbf{1 5}$ and the mixture was shaken for $2 \mathrm{~h}$. The resin was drained, then washed with DMF $(\times 5), \mathrm{DCM}(\mathrm{x} 5)$ and $\mathrm{DMF}(\times 5)$ to provide $\mathbf{1 7}$. Dopa derivative 18 (1.8 g, $4 \mathrm{mmol}, 10 \mathrm{eq})$ was dissolved in anhydrous DCM $(20 \mathrm{ml})$ and cooled to $0{ }^{\circ} \mathrm{C}$. To this solution, DIC (2.4 ml, $13 \mathrm{mmol}, 10 \mathrm{eq})$ was added and the mixture was warmed to room temperature and stirred for $30 \mathrm{~min}$. The reaction mixture was concentrated under a stream of nitrogen and subsequently redissolved in a 1:1 v/v mixture of DCM:DMF $(12 \mathrm{ml})$. This solution and catalytic amount of DMAP (10 mg, $0.08 \mathrm{mmol}, 0.2 \mathrm{eq}$ ) was transferred to the resin-bound peptide 17 and the mixture was shaken for $20 \mathrm{~h}$ at room temperature to afford the resin-bound depsipeptide 19. Completion of on-resin esterification was judged by mass spectrometry. The esterification solution was discharged and the excess of DOPA 18 was extracted from the discharged solution: (that is, a solution of $1 \mathrm{~N} \mathrm{HCl}$ was added to the discharged solution and mixed for $10 \mathrm{~min}$. The aqueous phase was extracted with EtOAc $(3 \times 50 \mathrm{ml})$ and combined organic layers were washed with brine before drying over magnesium sulfate. The EtOAc was evaporated under reduced pressure and the purification was performed using column chromatography $(\mathrm{MeOH} / \mathrm{DCM}, 2-10 \%))$. The resin was thoroughly washed with DMF $(\times 3)$ and DCM $(\times 10)$, then Boc deprotection and cleavage of the peptide from the resin were effected by treatment with 25 vol\% TFA in DCM. The volatile solvents were evaporated under a stream of nitrogen to afford the crude linear peptide 20 (250 mg, 51\% from starting resin) as a pale brown viscous oil which was used in the next step without purification. HRMS (ESI) $m / z$ : $[\mathrm{M}+\mathrm{H}]^{+} \mathrm{Calcd}$ for $\mathrm{C}_{67} \mathrm{H}_{100} \mathrm{BN}_{8} \mathrm{O}_{15}$ 1267.7396; found 1267.7401. 


\section{Cyclic depsipeptide 21}

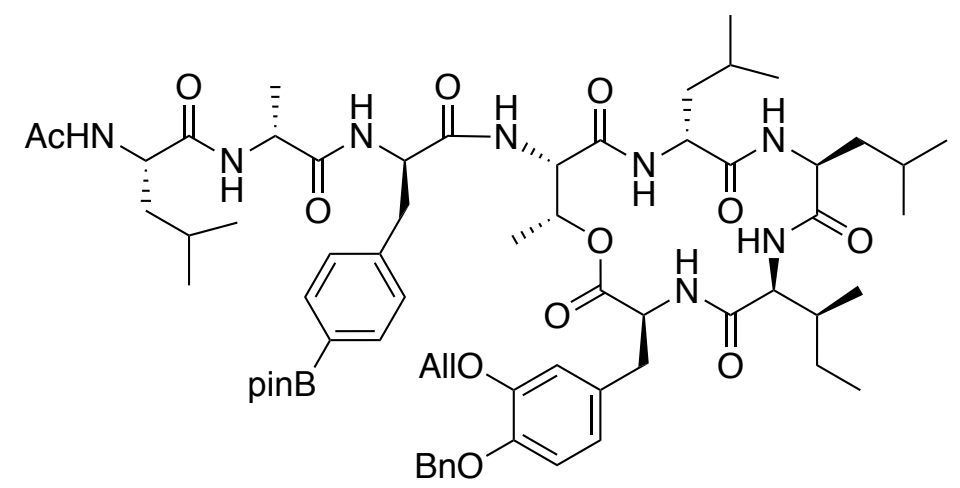

Crude linear peptide 20 (200 mg, $158 \mu \mathrm{mol})$ was dissolved in DMF/DCM (1:1, $200 \mathrm{ml}, 0.8 \mathrm{mM})$. HATU (66 mg, 0.174 mmol, 1.1 eq), HOAt (174 $\mu 1,1 \mathrm{M}$ in DMF, 1.1 eq) and DIPEA (85 $\mu 1,0.474$ mmol, 3 eq) were subsequently added and the reaction mixture was stirred for $18 \mathrm{~h}$. The reaction mixture was concentrated under a stream of nitrogen and water $(50 \mathrm{ml})$ was added. The aqueous phase was extracted with EtOAc $(5 \times 50 \mathrm{ml})$. The combined organic layers were washed with $1 \mathrm{~N} \mathrm{HCl}(50$ $\mathrm{ml})$, saturated sodium bicarbonate $(50 \mathrm{ml})$, and brine $(50 \mathrm{ml})$. The organic layers were dried over magnesium sulfate and the solvent was evaporated under reduced pressure to give the crude cyclic depsipeptide 21 (100 mg, 51\%) as a yellow oil which was used in the next step without further purification. HRMS (ESI) $m / z$ : $[\mathrm{M}+\mathrm{H}]^{+}$Calcd for $\mathrm{C}_{67} \mathrm{H}_{98} \mathrm{BN}_{8} \mathrm{O}_{14}$ 1249.7290; found 1249.7294 .

\section{Cyclic depsipeptide 22}

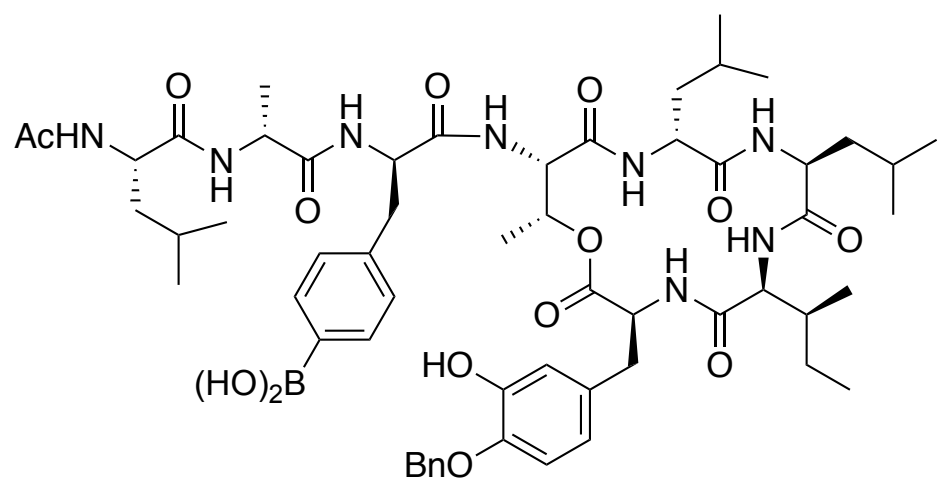

The crude peptide 20 (100 mg, $\sim 80 \mu \mathrm{mol})$ was dissolved in dry THF $(1 \mathrm{ml})$ under argon. Tetrakis(triphenylphosphine)palladium(0) $(17 \mathrm{mg}, 14 \mu \mathrm{mol})$ and phenylsilane $(1 \mu \mathrm{l}, 8 \mu \mathrm{mol})$ were 
added and the mixture was stirred overnight. The mixture was diluted with EtOAc $(20 \mathrm{ml})$ and washed with ammonium chloride $(10 \mathrm{ml})$, brine $(10 \mathrm{ml})$ and dried over magnesium sulfate. The solvent was evaporated and the crude deallylated peptide $(80 \mathrm{mg})$ was used as a yellow viscous oil in the next step without further purification. HRMS (ESI) $m / z$ : $[\mathrm{M}+\mathrm{H}]^{+}$Calcd for $\mathrm{C}_{64} \mathrm{H}_{94} \mathrm{BN}_{8} \mathrm{O}_{14}$ 1209.6977; found 1209.6976.

Crude deallylated peptide $(80 \mathrm{mg})$ was dissolved in a mixture of water/acetone $(1: 2,10 \mathrm{ml})$. Ammonium acetate ( $80 \mathrm{mg}, \sim 6 \mathrm{eq}$ ) and sodium periodate ( $29 \mathrm{mg}, \sim 6 \mathrm{eq}$ ) were added and the reaction mixture was stirred overnight at room temperature. The mixture was concentrated under reduced pressure and extracted with EtOAc $(3 \times 50 \mathrm{ml})$. Combined organic layers were washed with brine (50 $\mathrm{ml})$ and dried over sodium sulfate. The solvent was evaporated under vacuum to yield the crude peptide 22 (61 mg, 68\%) which was used as a yellow viscous oil in the next step without further purification. HRMS (ESI) $m / z$ : $[\mathrm{M}+\mathrm{H}]^{+}$Calcd for $\mathrm{C}_{58} \mathrm{H}_{84} \mathrm{BN}_{8} \mathrm{O}_{14}$ 1127.6195; found 1127.6198.

\section{Protected seongsanamide B (23)}

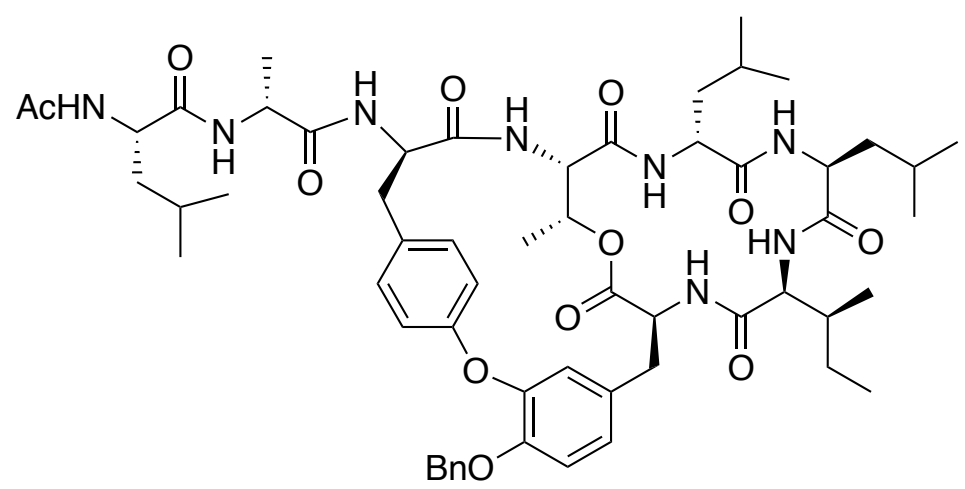

To an oven dried 2-neck $100 \mathrm{ml}$ RB flask, crude peptide $22(60 \mathrm{mg}), \mathrm{Cu}(\mathrm{OAc})_{2}(20 \mathrm{mg}, 112 \mu \mathrm{mol})$ and molecular sieves $(222 \mathrm{mg})$ were added and the flask was left under vacuum for $4 \mathrm{~h}$. The flask was then filled with argon and DCM $(26 \mathrm{ml}), \mathrm{NEt}_{3}(0.55 \mathrm{ml}, 4 \mathrm{mmol})$ and pyridine $(5 \mu \mathrm{l}, 7 \mu \mathrm{mol})$ were added. The reaction was stirred for $96 \mathrm{~h}$ then filtered through celite and the solid washed with $\operatorname{DCM}(2 \times 25 \mathrm{ml})$. The filtrate was washed with $1 \mathrm{~N} \mathrm{HCl}(25 \mathrm{ml})$, brine $(25 \mathrm{ml})$ and dried over 
magnesium sulfate. The solvent was evaporated under reduced pressure and the residue was purified using HPLC to afford compound $\mathbf{2 3}$ (15 mg, 26\% yield after HPLC) as a white solid. ${ }^{\mathbf{1}} \mathbf{H}$ NMR (500 $\left.\mathrm{MHz}_{\mathrm{CDCl}}\right) \delta 7.88(\mathrm{~d}, J=6.5 \mathrm{~Hz}, 1 \mathrm{H}), 7.59(\mathrm{~s}, 1 \mathrm{H}), 7.42(\mathrm{~d}, J=7.6 \mathrm{~Hz}, 3 \mathrm{H}), 7.34(\mathrm{t}, J=7.5 \mathrm{~Hz}, 2 \mathrm{H})$, $7.29(\mathrm{~d}, J=7.6 \mathrm{~Hz}, 1 \mathrm{H}), 7.23-7.14(\mathrm{~m}, 2 \mathrm{H}), 7.03(\mathrm{~s}, 1 \mathrm{H}), 6.86(\mathrm{~d}, J=8.4 \mathrm{~Hz}, 1 \mathrm{H}), 6.73(\mathrm{~d}, J=8.4 \mathrm{~Hz}$, $1 \mathrm{H}), 6.55(\mathrm{~s}, 1 \mathrm{H}), 5.58(\mathrm{~m}, 1 \mathrm{H}), 5.21-5.11(\mathrm{~m}, 2 \mathrm{H}), 4.55-4.49(\mathrm{~m}, 2 \mathrm{H}), 4.41-4.27(\mathrm{~m}, 4 \mathrm{H}), 4.23(\mathrm{~m}$, $1 \mathrm{H}), 3.58(\mathrm{~s}, 1 \mathrm{H}), 3.15(\mathrm{~m}, 1 \mathrm{H}), 3.0 .2(\mathrm{~m}, 1 \mathrm{H}), 2.39(\mathrm{~s}, 1 \mathrm{H}), 2.10(\mathrm{~s}, 3 \mathrm{H}), 1.80(\mathrm{~m}, 1 \mathrm{H}), 1.71(\mathrm{~m}, 1 \mathrm{H})$, $1.67-1.54(\mathrm{~m}, 11 \mathrm{H}), 1.40(\mathrm{~d}, J=7.1 \mathrm{~Hz}, 3 \mathrm{H}), 1.05(\mathrm{~m}, 1 \mathrm{H}), 0.98-0.86(\mathrm{~m}, 22 \mathrm{H}), 0.60(\mathrm{~d}, J=6.4 \mathrm{~Hz}$, 3H). ${ }^{13} \mathrm{C}$ NMR $\left(126 \mathrm{MHz}, \mathrm{CDCl}_{3}\right) \delta 173.2,172.7,172.7,172.2,172.2,172.2,171.6,171.5,171.5$, $171.4,169.6,169.5,170.0,159.5,159.2,157.0,153.8,148.5,148.2,137.0,131.3,130.3,128.5,127.9$, $127.3,124.7,121.5,115.8,71.4,70.0,58.7,55.5,52.8,52.2,48.7,40.0,38.6,36.4,36.1,33.6,29.7$, 25.2, 249, 24.8, 24.7, 23.0, 22.7, 22.5, 22.4, 22.3, 21.9, 17.5, 16.8, 15.5, 10.4. HRMS (ESI) $m / z$ : $[\mathrm{M}+\mathrm{H}]^{+}$Calcd for $\mathrm{C}_{58} \mathrm{H}_{81} \mathrm{~N}_{8} \mathrm{O}_{12}$ 1081.5968; found 1081.5969 .

\section{Seongsanamide B 2}

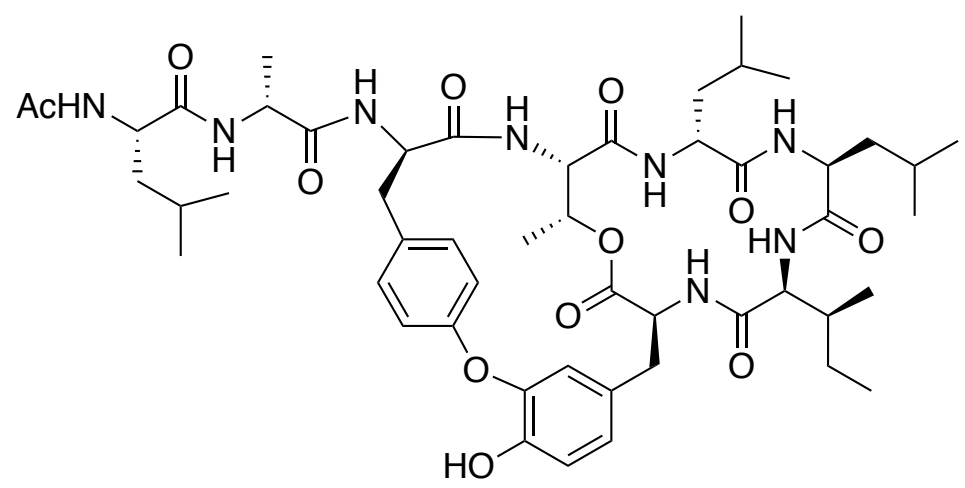

Peptide 23 (7.0 mg, $6.5 \mu \mathrm{mol})$ was dissolved in a mixture of $\mathrm{MeOH} / 1 \mathrm{~N} \mathrm{HCl} / \mathrm{AcOH}(1: 0.2: 0.1,4 \mathrm{ml})$ and $10 \mathrm{wt} \% \mathrm{Pd} / \mathrm{C}(1 \mathrm{mg}, 13 \% \mathrm{w} / \mathrm{w})$ was added. The mixture was stirred for $10 \mathrm{~h}$ under an atmosphere of hydrogen at $200 \mathrm{psi}$. The reaction was filtered through celite, concentrated under reduced pressure and purified using preparative HPLC to yield seongsanamide B 2 (5.0 $\mathrm{mg}, 78 \%$ yield $)$ as a white solid. ${ }^{1}$ H NMR (500 MHz, DMSO-d $\left.d_{6}\right) \delta 9.31(\mathrm{~s}, 1 \mathrm{H}), 8.26(\mathrm{~d}, J=4.4 \mathrm{~Hz}, 1 \mathrm{H}), 8.21-8.15(\mathrm{~m}, 2 \mathrm{H})$, $8.13(\mathrm{~d}, J=6.1 \mathrm{~Hz}, 1 \mathrm{H}), 8.11(\mathrm{~d}, J=5.4 \mathrm{~Hz}, 1 \mathrm{H}), 7.78(\mathrm{~d}, J=9.4 \mathrm{~Hz}, 1 \mathrm{H}), 7.52(\mathrm{~d}, J=8.7 \mathrm{~Hz}, 1 \mathrm{H}), 7.18$ 
(s, 2H), $6.98(\mathrm{~m}, 1 \mathrm{H}), 6.80(\mathrm{~d}, J=8.2 \mathrm{~Hz}, 1 \mathrm{H}), 6.66(\mathrm{dd}, J=8.4,2.1 \mathrm{~Hz}, 1 \mathrm{H}), 6.43(\mathrm{~d}, J=2.1 \mathrm{~Hz}, 1 \mathrm{H})$, $5.15(\mathrm{q}, J=7.3,1 \mathrm{H}), 4.57(\mathrm{~m}, 1 \mathrm{H}), 4.50(\mathrm{~m}, 1 \mathrm{H}), 4.35(\mathrm{~m}, 1 \mathrm{H}), 4.27(\mathrm{~m}, 1 \mathrm{H}), 4.23(\mathrm{~d}, J=7.5 \mathrm{~Hz}, 1 \mathrm{H})$, $4.18(\mathrm{~m}, 1 \mathrm{H}), 3.98(\mathrm{~m}, 1 \mathrm{H}), 3.72(\mathrm{~m}, 1 \mathrm{H}), 3.03-2.94(\mathrm{~m}, 2 \mathrm{H}), 2.82-2.70(\mathrm{~m}, 2 \mathrm{H}), 1.96-1.84(\mathrm{~m}, 2 \mathrm{H})$, $1.85(\mathrm{~s}, 3 \mathrm{H}), 1.63(\mathrm{~m}, 1 \mathrm{H}), 1.54(\mathrm{~m}, 1 \mathrm{H}), 1.50(\mathrm{~m}, 1 \mathrm{H}), 1.47-1.41(\mathrm{~m}, 3 \mathrm{H}), 1.41-1.31(\mathrm{~m}, 5 \mathrm{H}), 1.16$ (d, $J=7.0 \mathrm{~Hz}, 3 \mathrm{H}), 0.96(\mathrm{~m}, 1 \mathrm{H}), 0.89$ (d, J=4.8 Hz, 3H), 0.88 (d, J=4.9 Hz, 3H), 0.84 (d, $J=6.5 \mathrm{~Hz}$,

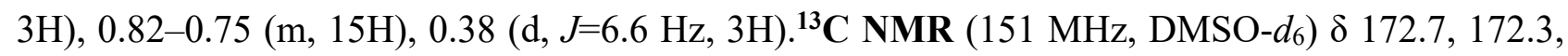
$172.1,171.7,171.6,170.9,170.3,170.0,168.4,156.2,146.8,146.3,132.3,128.5,125.0,120.7,117.3$, $116.4,70.4,56.2,56.1,51.9,50.9,47.8,41.7,24.8,24.7,24.7,24.5,23.3,23.1,22.9,22.7,22.2,21.8$, 18.4, 17.1, 15.8, 10.6. HRMS (ESI) $m / z:[\mathrm{M}+\mathrm{H}]^{+}$Calcd for $\mathrm{C}_{51} \mathrm{H}_{75} \mathrm{~N}_{8} \mathrm{O}_{12}$ 991.5499; found 991.5499. 
${ }^{1} \mathrm{H}$ NMR and ${ }^{13} \mathrm{C}$ NMR spectra of benzyl (S)-3-(3-acetyl-4-(benzyloxy)phenyl)-2-((diboc)amino)propanoate $\left(600 \mathrm{MHz}, \mathrm{CDCl}_{3}\right)$
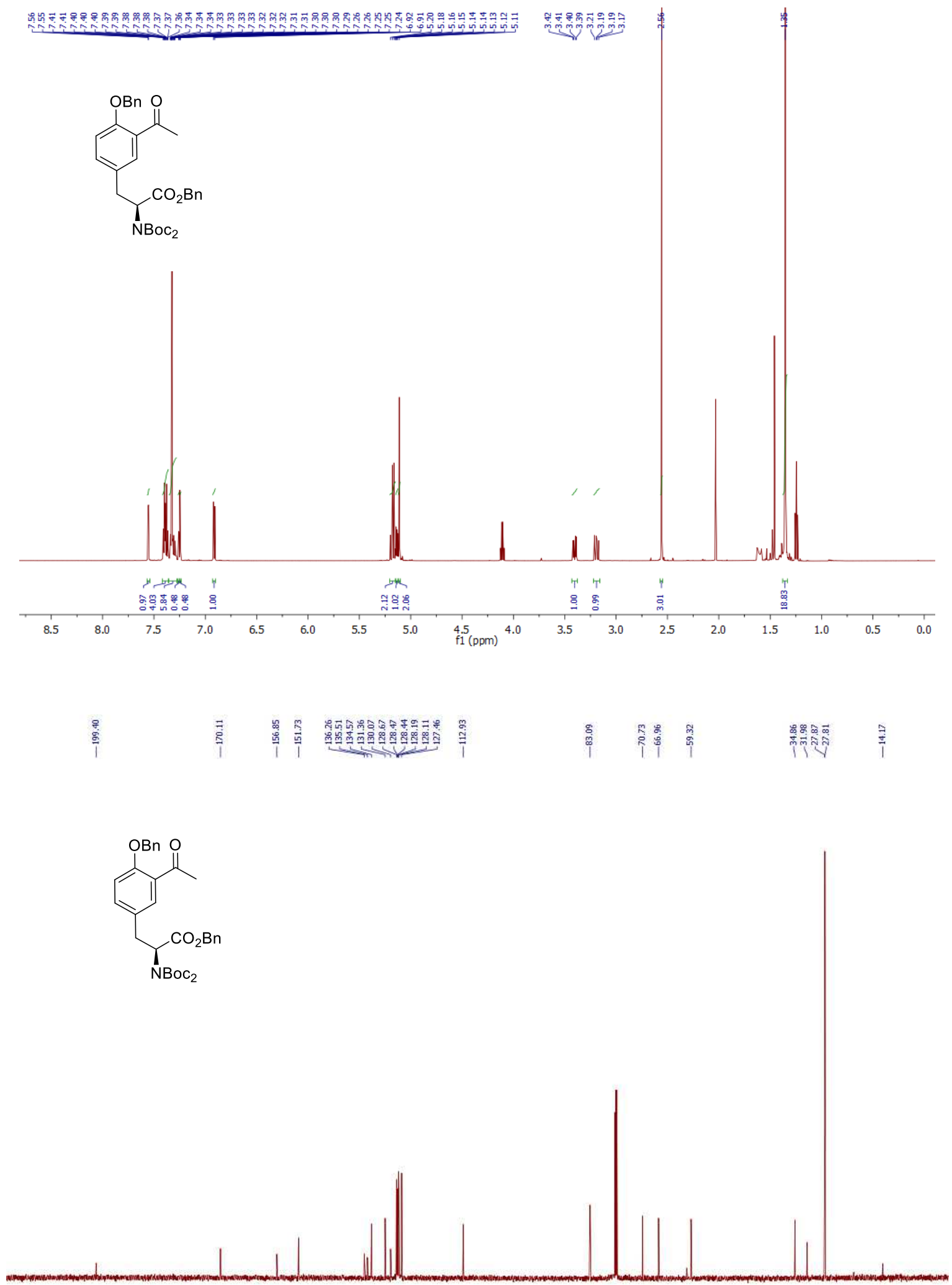

\begin{tabular}{llllllllllllllllllllllllllll}
\hline 20 & 210 & 200 & 190 & 180 & 170 & 160 & 150 & 140 & 130 & 120 & 110 & 100 & 90 & 80 & 70 & 60 & 50 & 40 & 30 & 20 & 10 & 0
\end{tabular} 
${ }^{1} \mathrm{H}$ NMR and ${ }^{13} \mathrm{C}$ NMR spectra of DOPA $8\left(600 \mathrm{MHz}, \mathrm{CDCl}_{3}\right)$
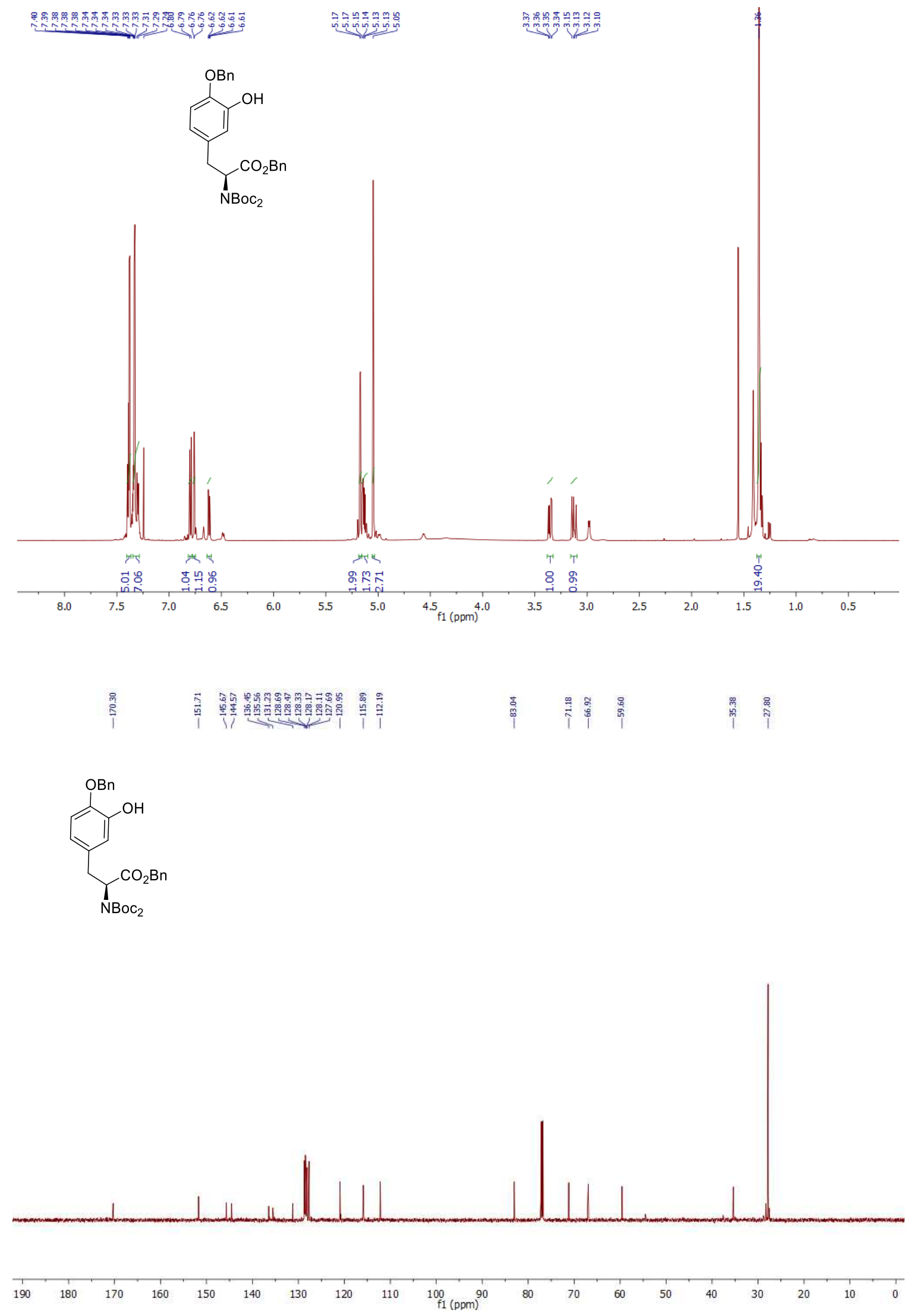
${ }^{1} \mathrm{H}$ NMR and ${ }^{13} \mathrm{C}$ NMR spectra of protected DOPA $\left(400 \mathrm{MHz}, \mathrm{CDCl}_{3}\right)$
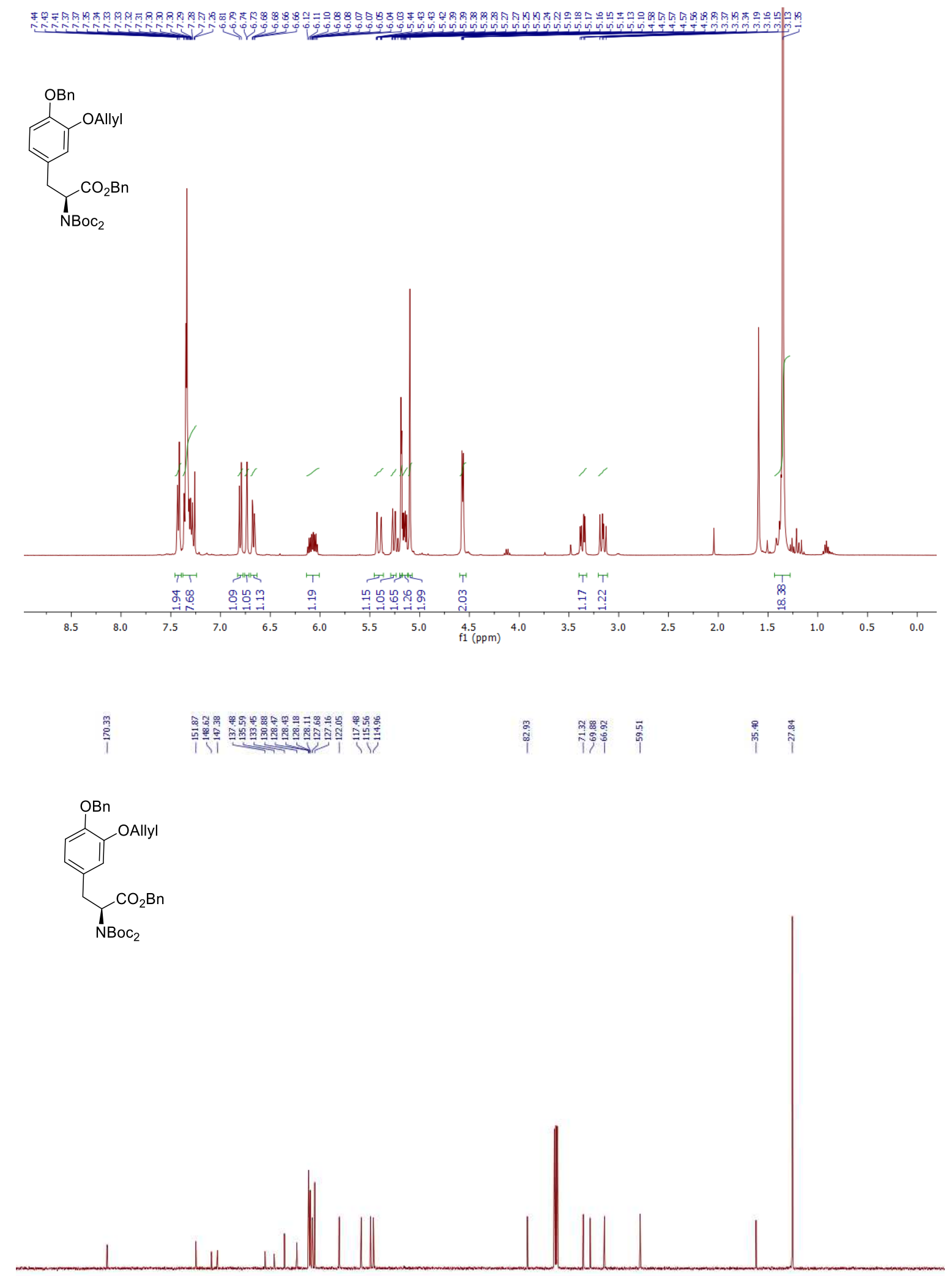

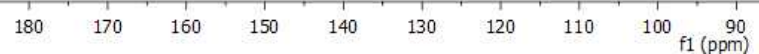


${ }^{1} \mathrm{H}$ NMR and ${ }^{13} \mathrm{C}$ NMR spectra of DOPA $18\left(500 \mathrm{MHz}, \mathrm{CDCl}_{3}\right)$
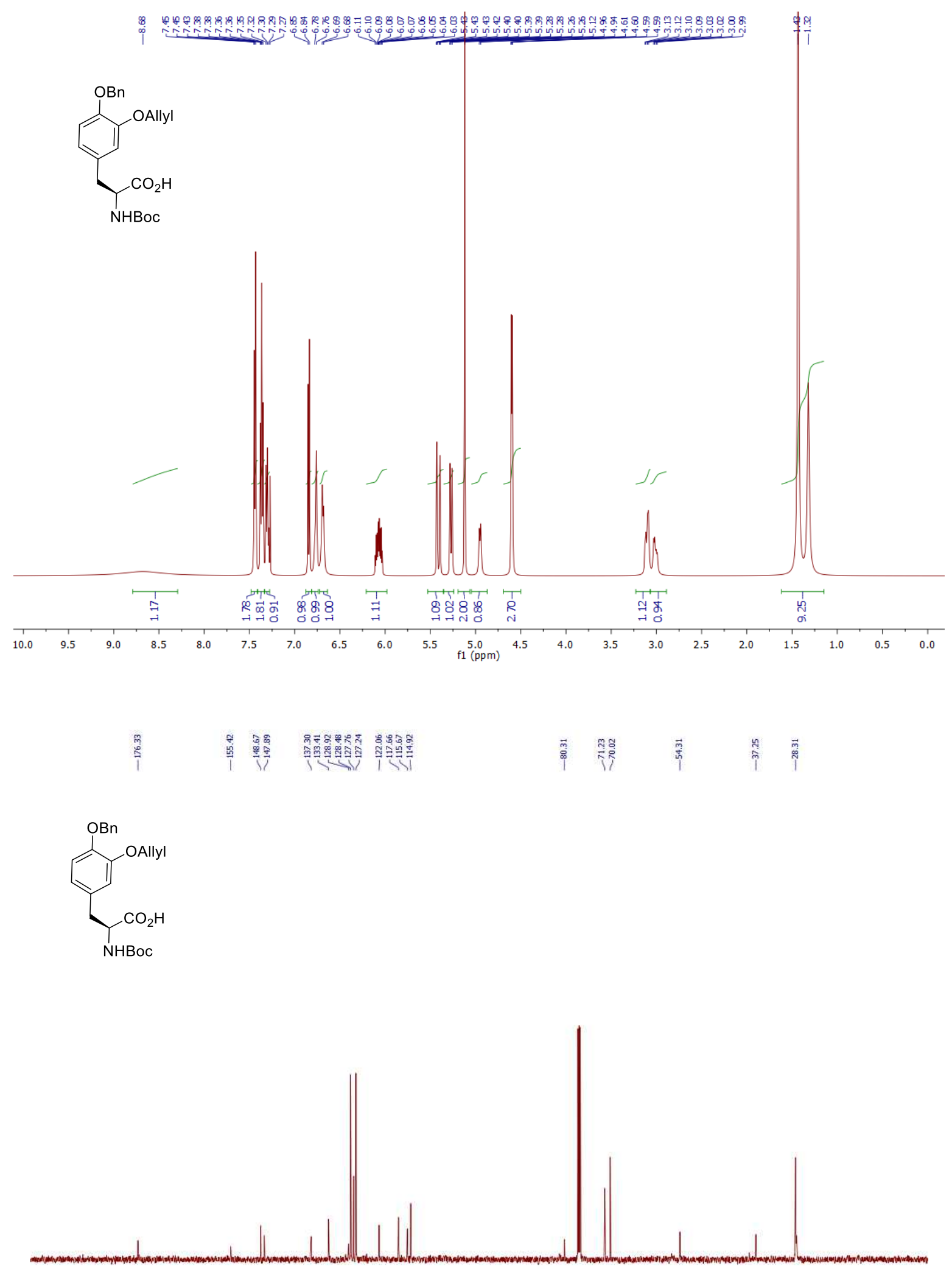

\begin{tabular}{lllllllllllllllllllllll}
\hline 0 & 190 & 180 & 170 & 160 & 150 & 140 & 130 & 120 & 110 & 100 & 90 & 80 & 70 & 60 & 50 & 40 & 30 & 20 & 10 & 0
\end{tabular} 
Mass spectrum of DOPA 18

Boc-Tyr(Bn)(3-Oally)-OH \#35 RT: $0.32 \quad$ AV: $1 \quad$ NL: $1.48 E 8$
T: $F$ TMS + P ESIFlll ms [100.0000-10000000]

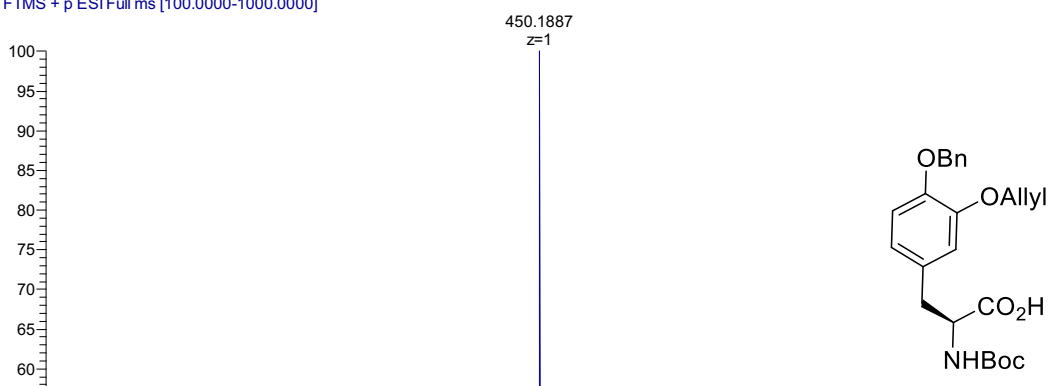

$\begin{array}{cc}447.1806 & 448.0011 \\ z=? & z=?\end{array}$

449

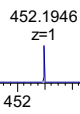

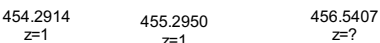

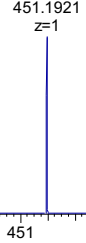

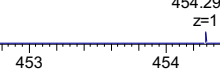

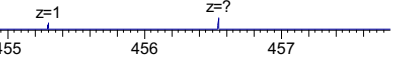


${ }^{1} \mathrm{H}$ NMR and ${ }^{13} \mathrm{C}$ NMR spectra of Boc-D-Phe(4-I)-OMe (600 MHz, $\mathrm{CDCl}_{3}$ )

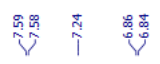
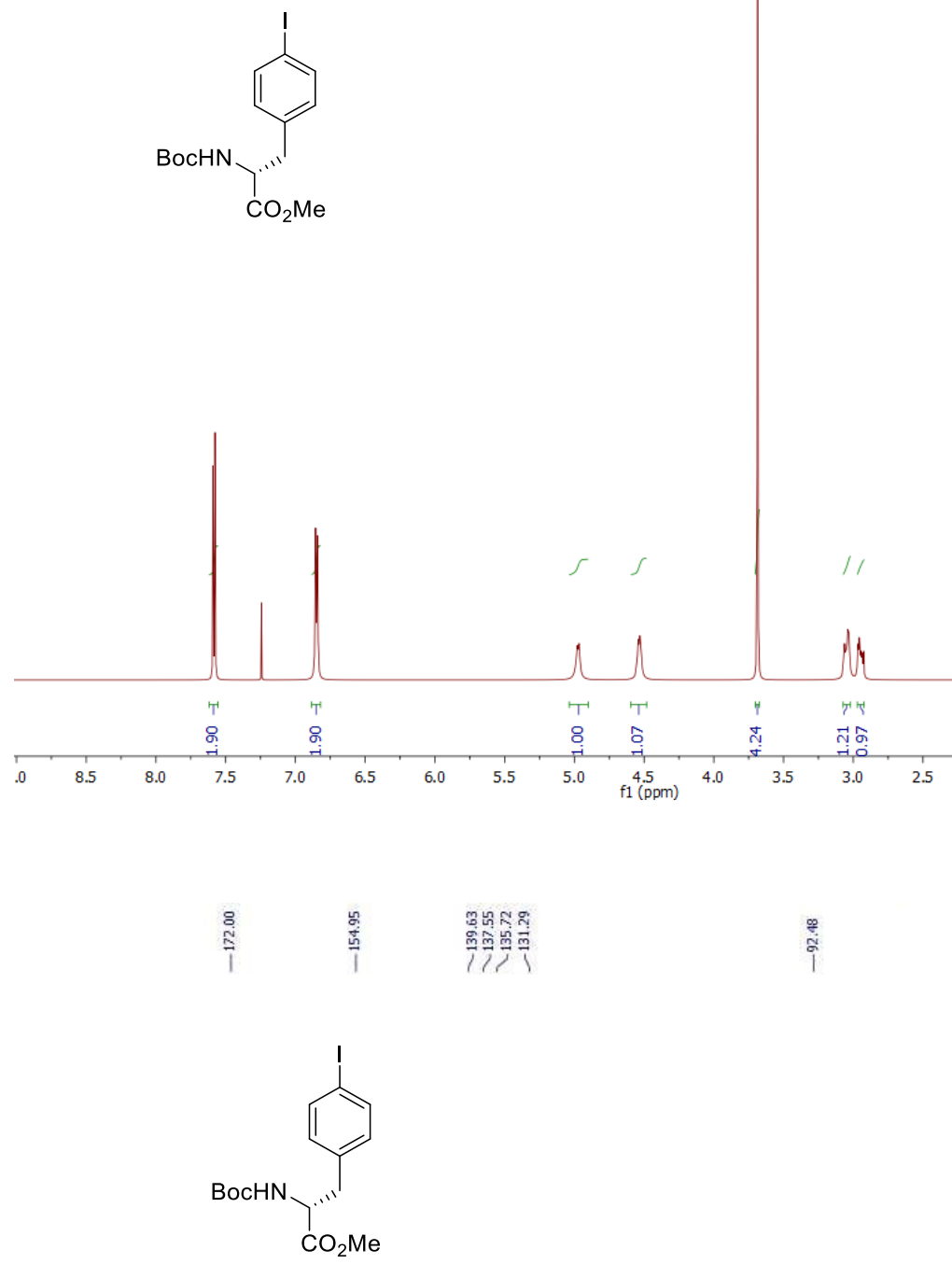

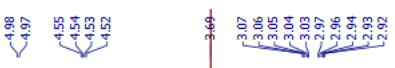

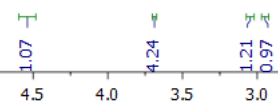

$41(\mathrm{ppm})$

品
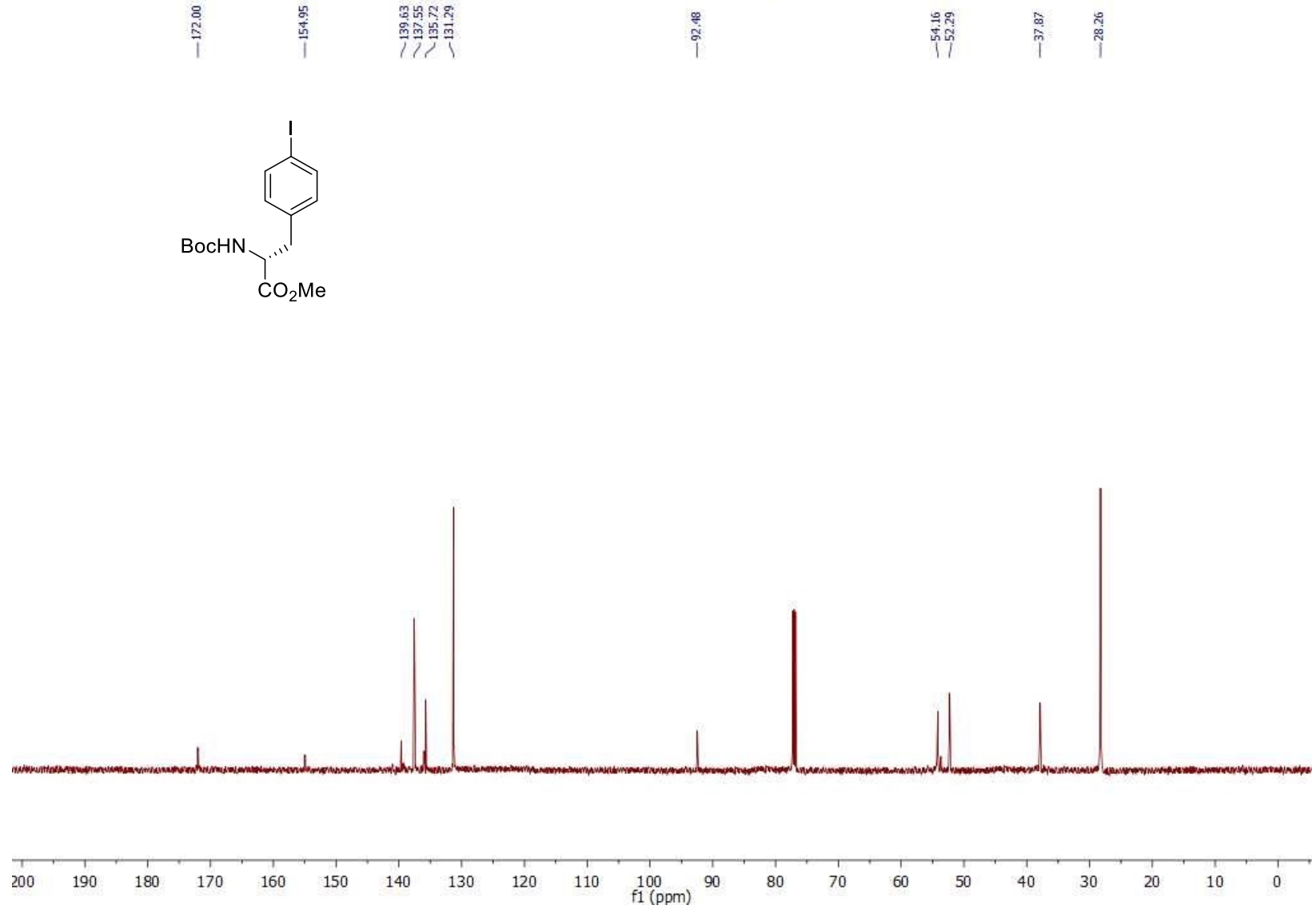

S33 
${ }^{1} \mathrm{H}$ NMR and ${ }^{13} \mathrm{C}$ NMR spectra of Boc(Cbz)-D-Phe(4-I)-OtBu (600 MHz, $\left.\mathrm{CDCl}_{3}\right)$
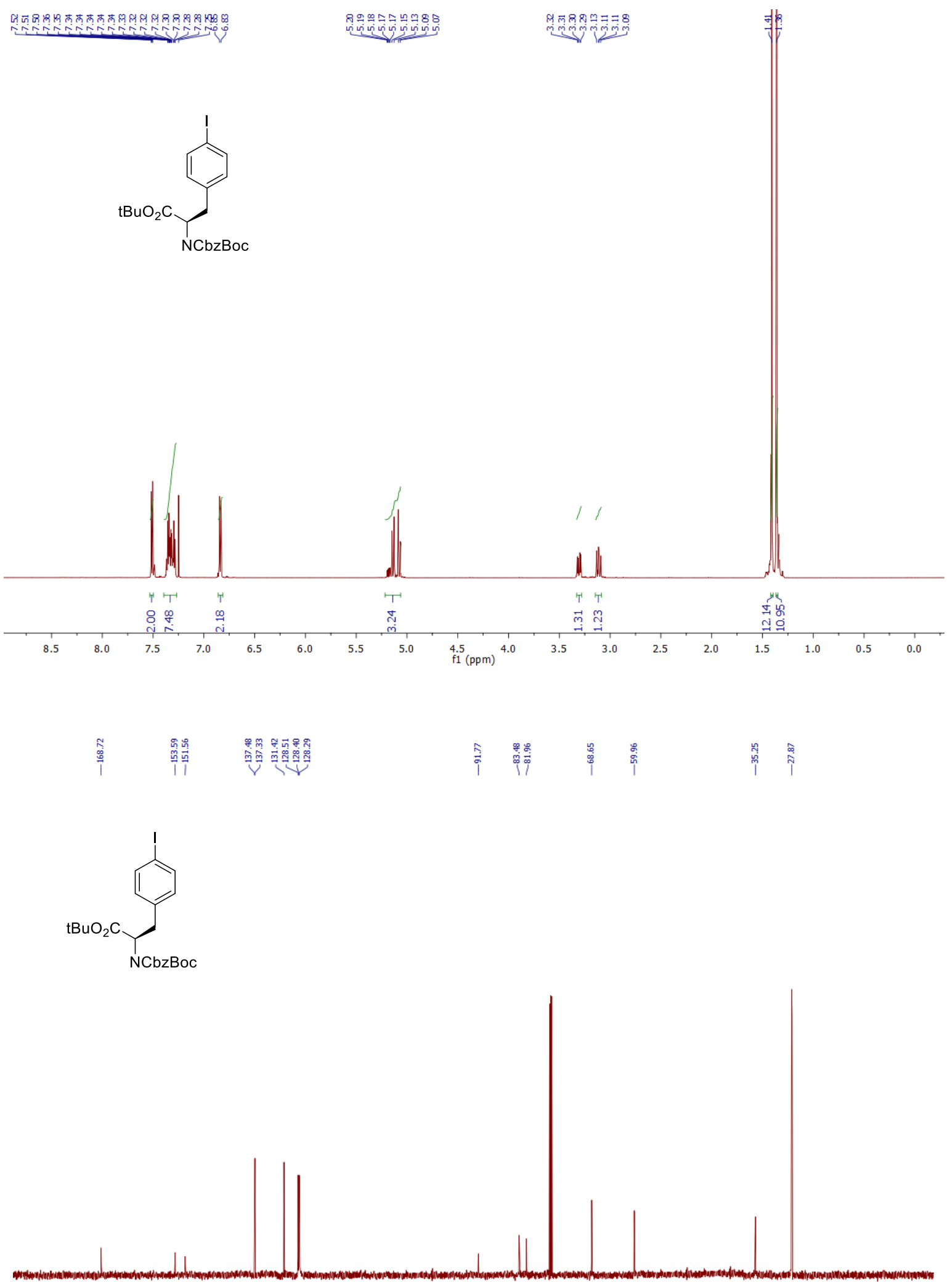

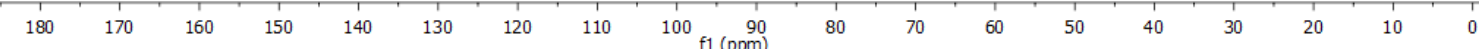


${ }^{1} \mathrm{H}$ NMR and ${ }^{13} \mathrm{C}$ NMR spectra of Cbz(Boc)-D-Phe(4-neopentylglycolatoboronato)-O $t \mathrm{Bu}(500 \mathrm{MHz}$, $\left.\mathrm{CDCl}_{3}\right)$
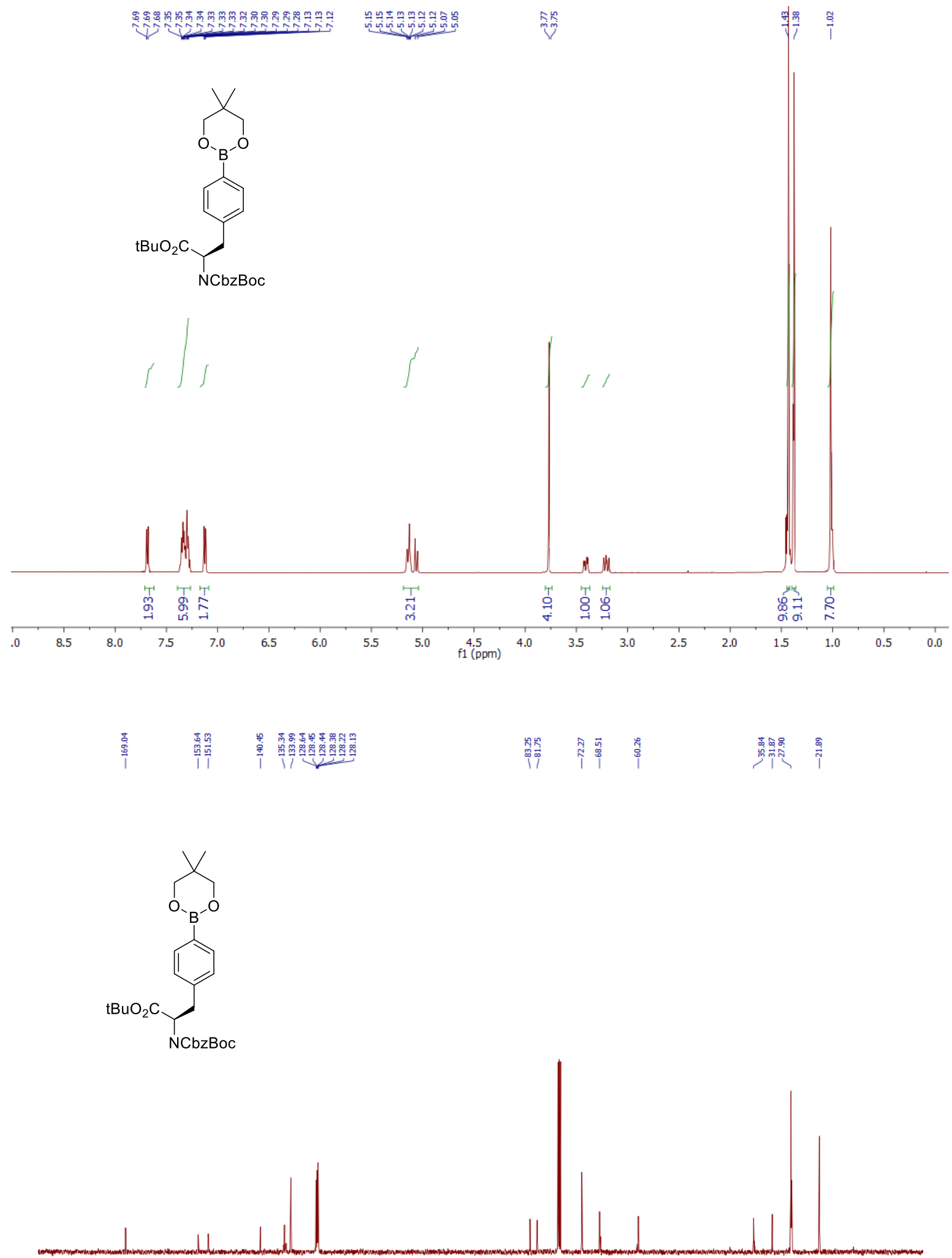

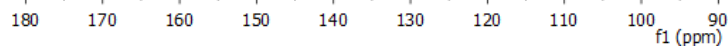


${ }^{1} \mathrm{H} \mathrm{NMR}$ and ${ }^{13} \mathrm{C} \mathrm{NMR}$ spectra of isodityrosine $9\left(600 \mathrm{MHz}, \mathrm{CDCl}_{3}\right)$

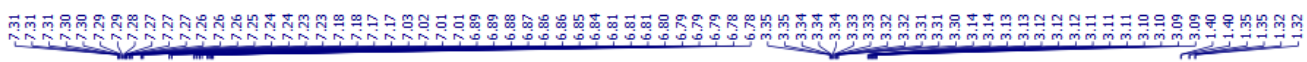
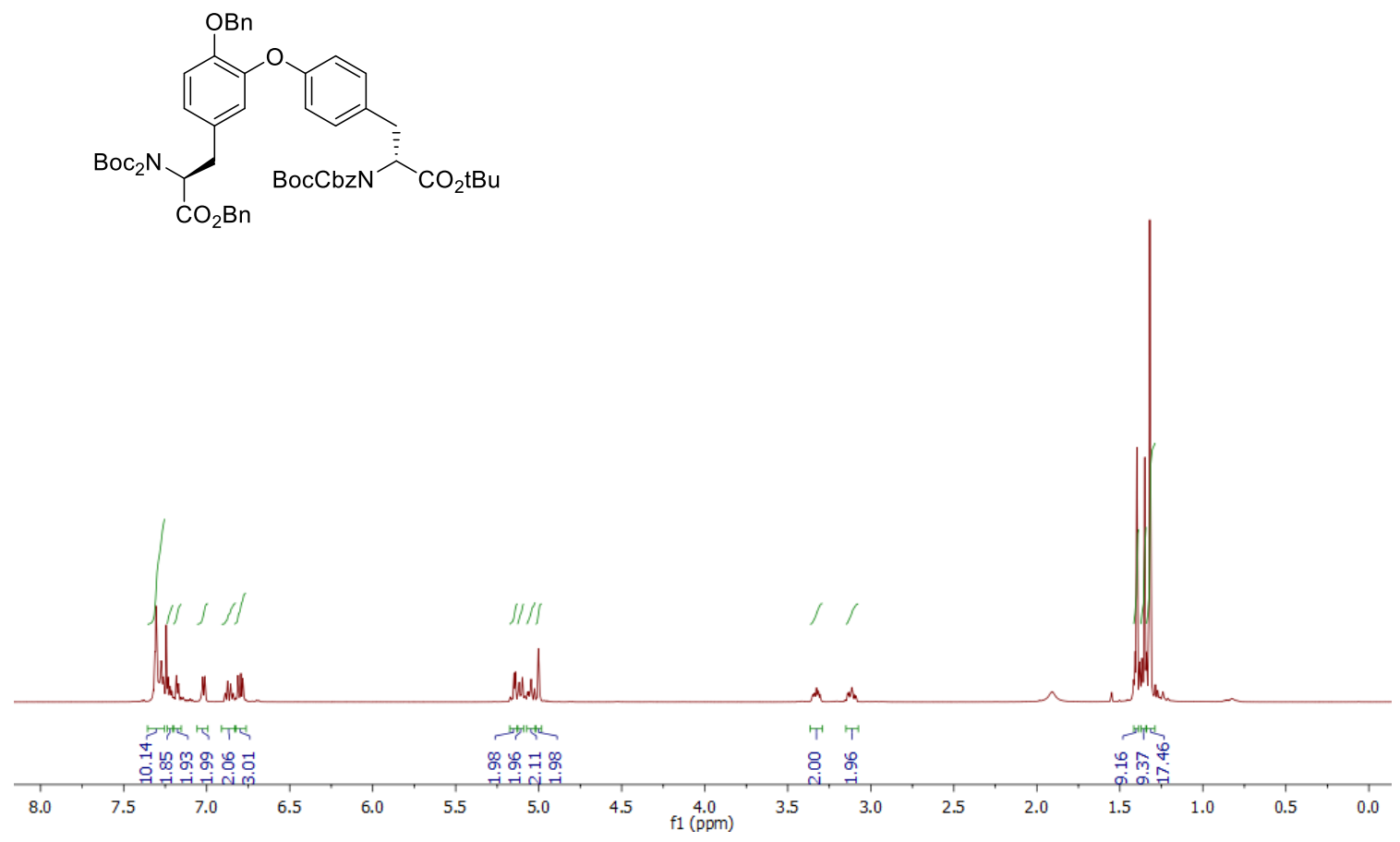

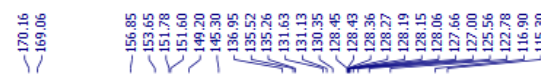

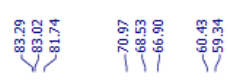

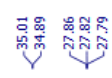
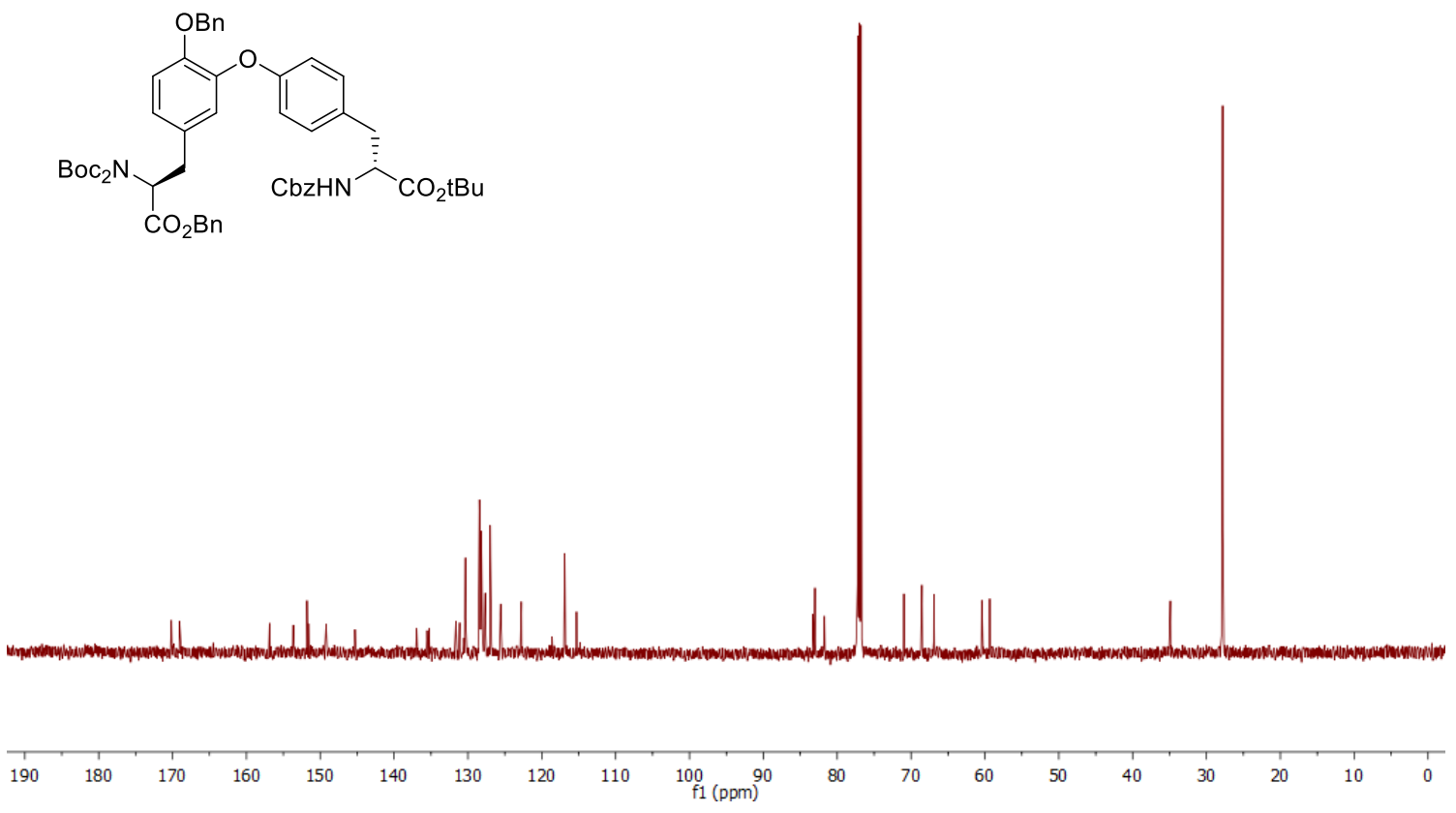

S36 
${ }^{1} \mathrm{H}$ NMR and ${ }^{13} \mathrm{C}$ NMR spectra of Thr-O $t \mathrm{Bu}\left(600 \mathrm{MHz}, \mathrm{CDCl}_{3}\right)$
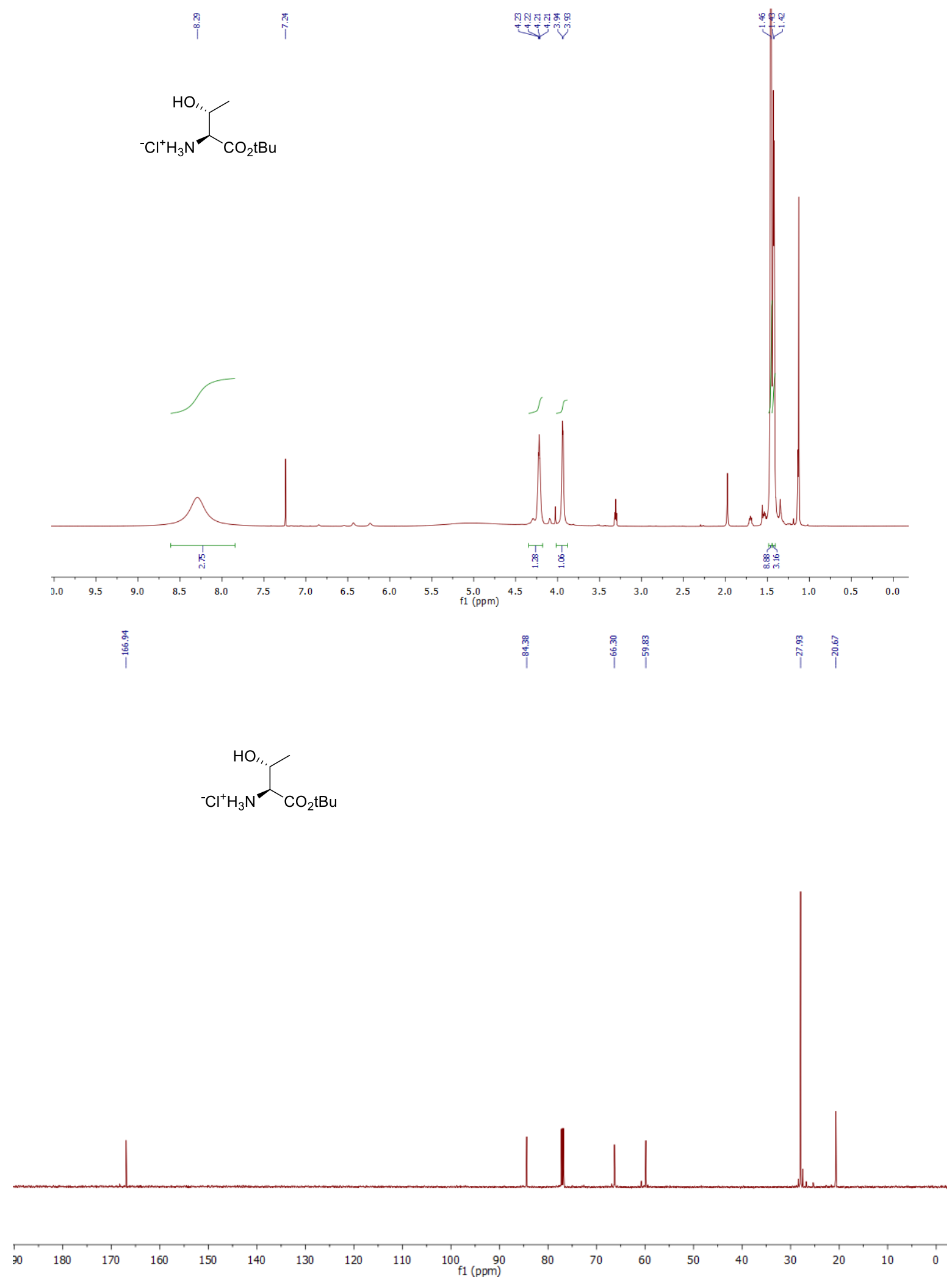
${ }^{1} \mathrm{H}$ NMR and ${ }^{13} \mathrm{C}$ NMR spectra of compound $10\left(600 \mathrm{MHz}, \mathrm{CDCl}_{3}\right)$

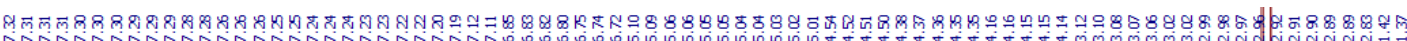
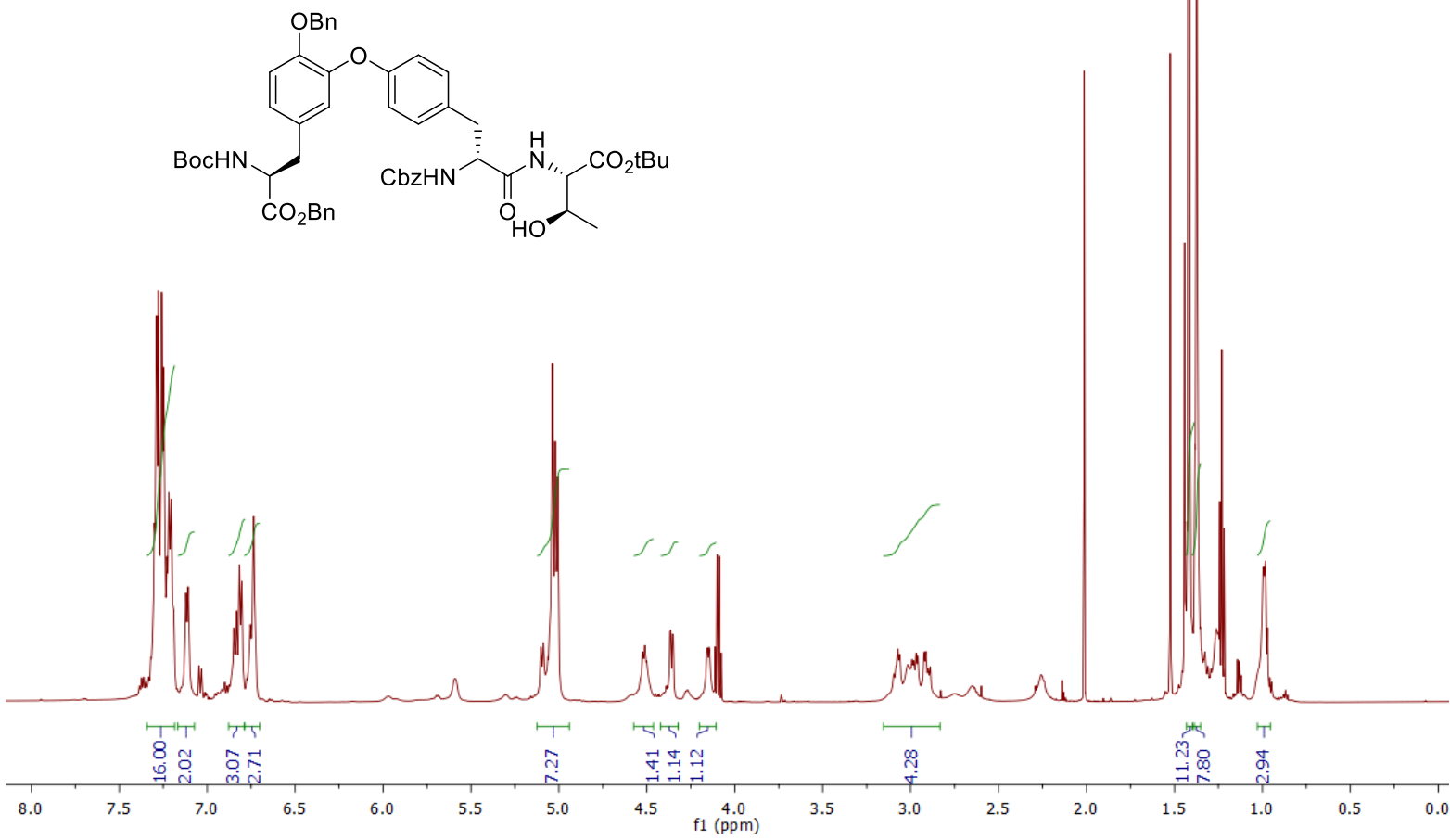

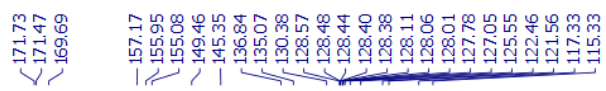

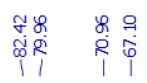

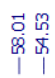
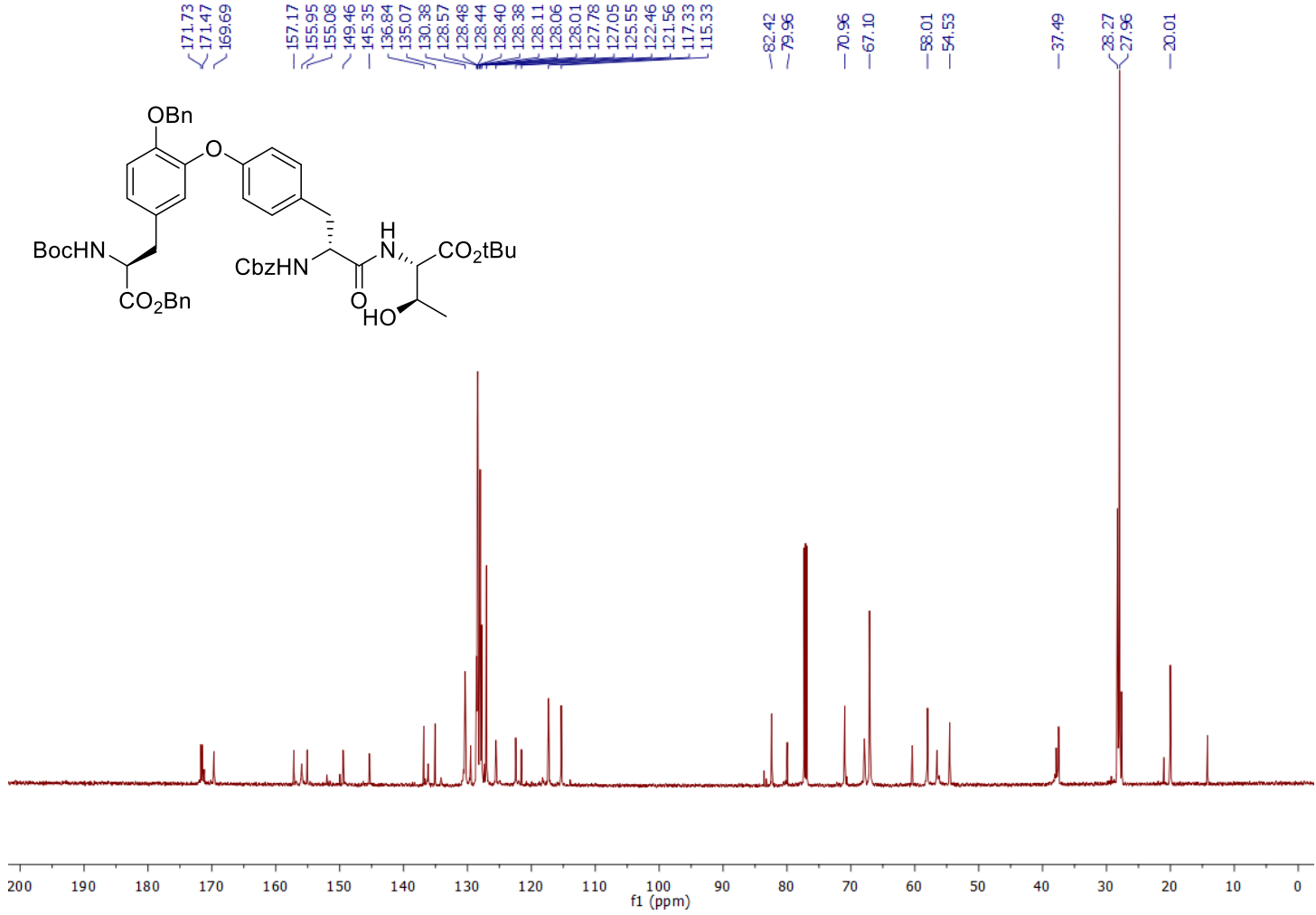

S38 
${ }^{1} \mathrm{H}$ NMR and ${ }^{13} \mathrm{C}$ NMR spectra of compound $12\left(600 \mathrm{MHz}, \mathrm{CDCl}_{3}\right)$

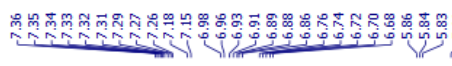

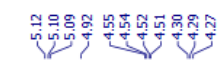

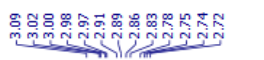

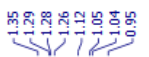

$\vec{i}$
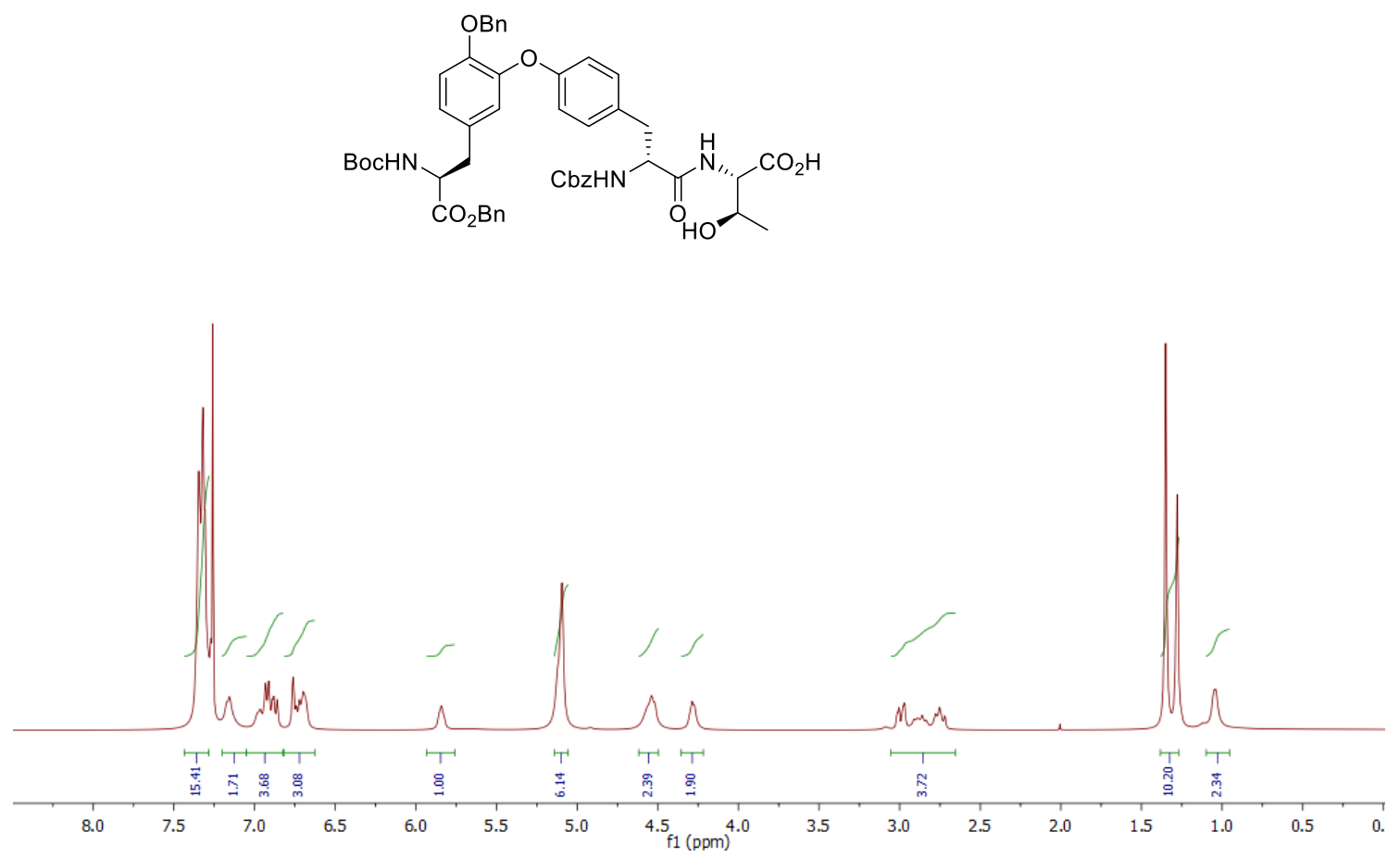

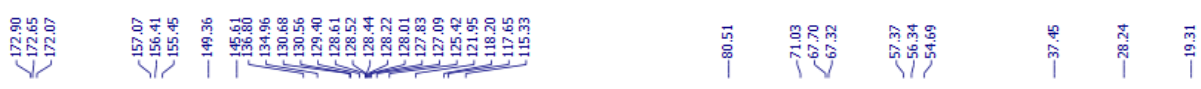
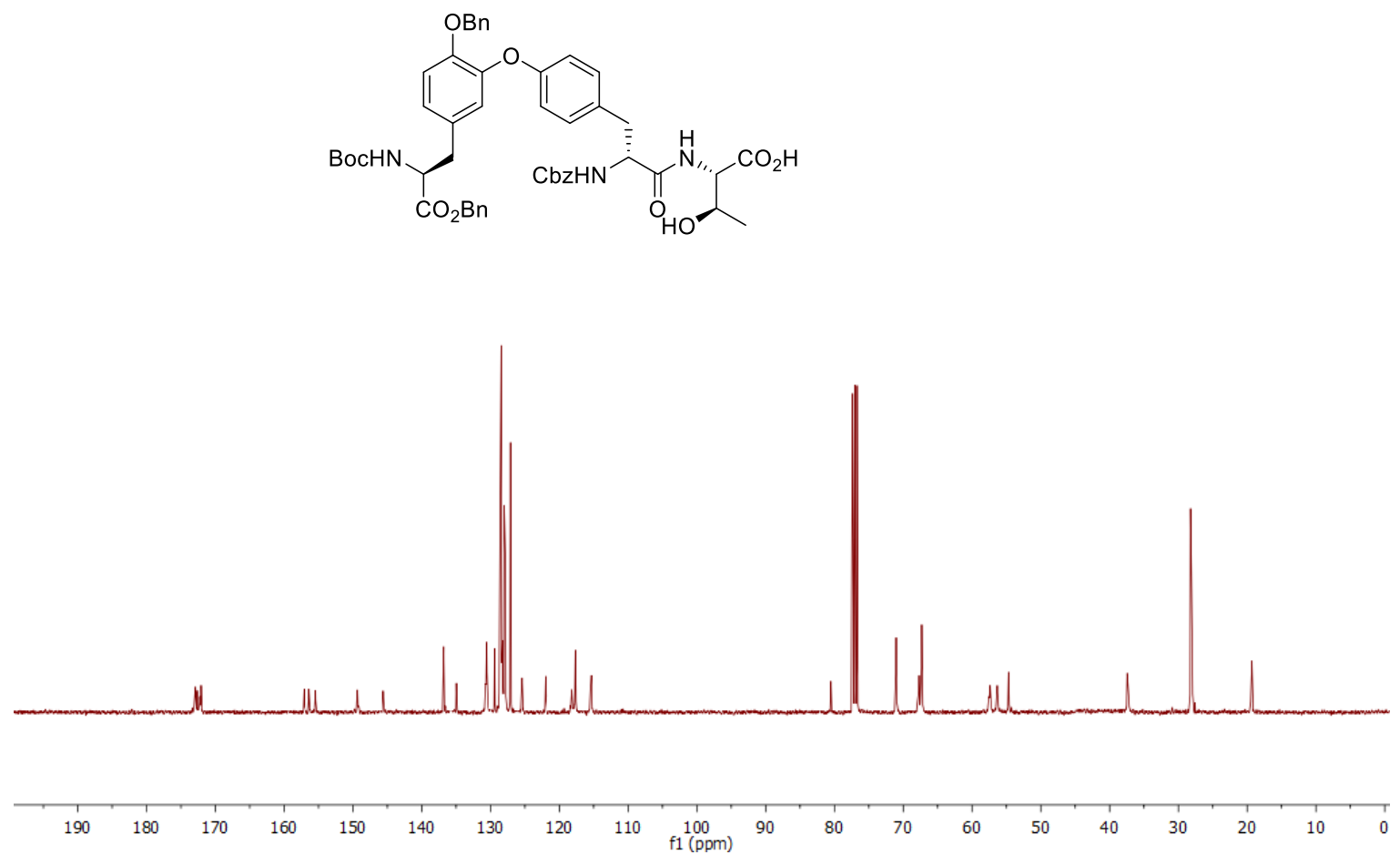

S39 
${ }^{1} \mathrm{H}$ NMR and ${ }^{13} \mathrm{C}$ NMR spectra of Fmoc-D-Leu-Leu-Ile

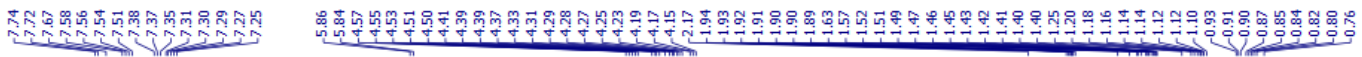<smiles>CC(C)C[C@H](NC(=O)[C@H](NC(=O)C(C)C)C(=O)O)C(=O)N[C@@H](CC(C)C)C(C)C</smiles>
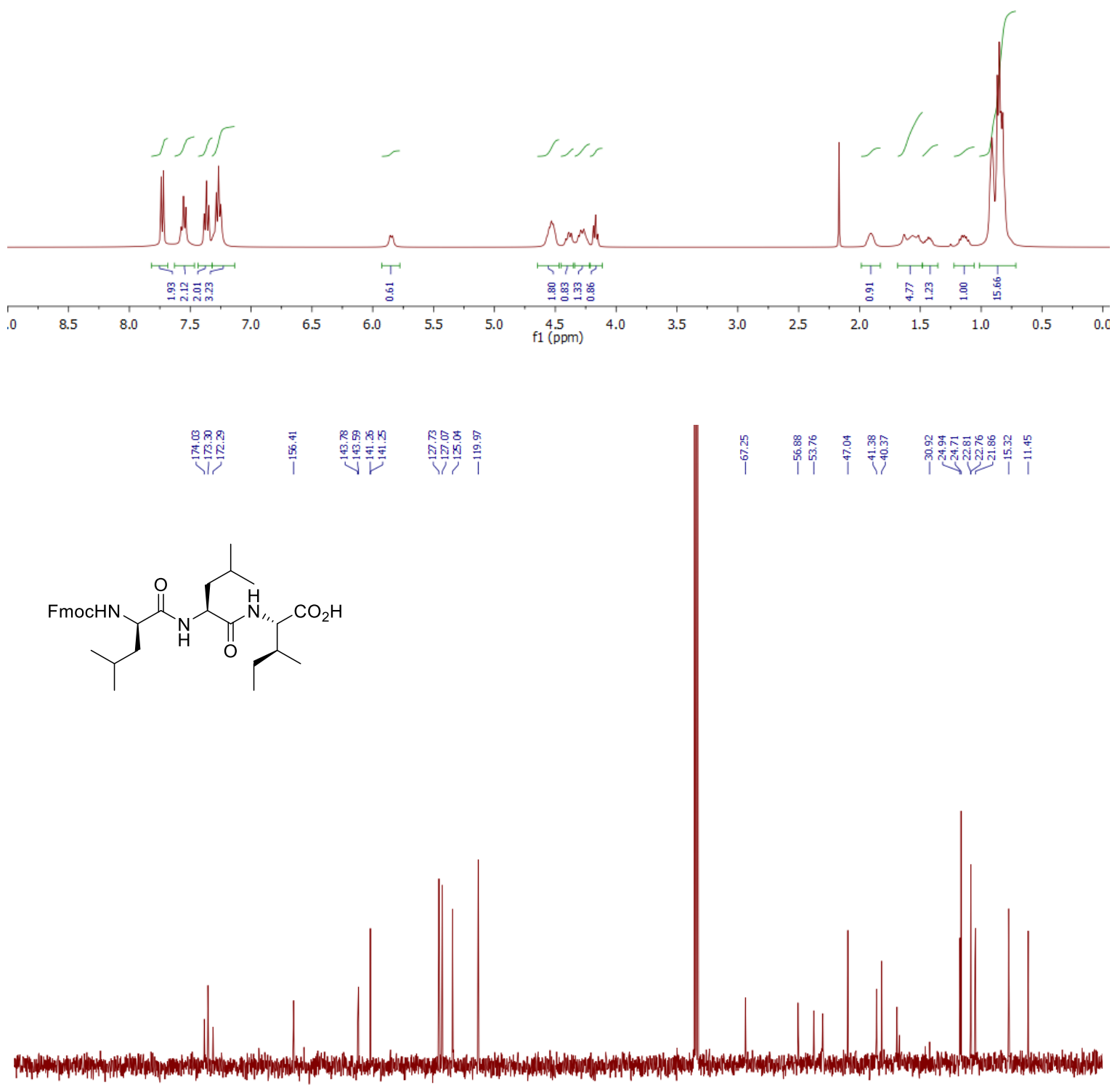

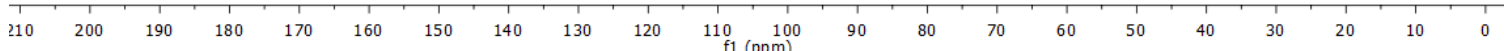


${ }^{1} \mathrm{H}$ NMR and ${ }^{13} \mathrm{C}$ NMR spectra of Fmoc-D-Leu-Leu-Ile-O $t \mathrm{Bu}$

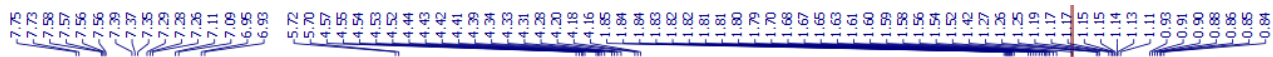

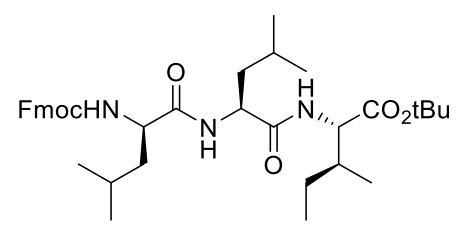
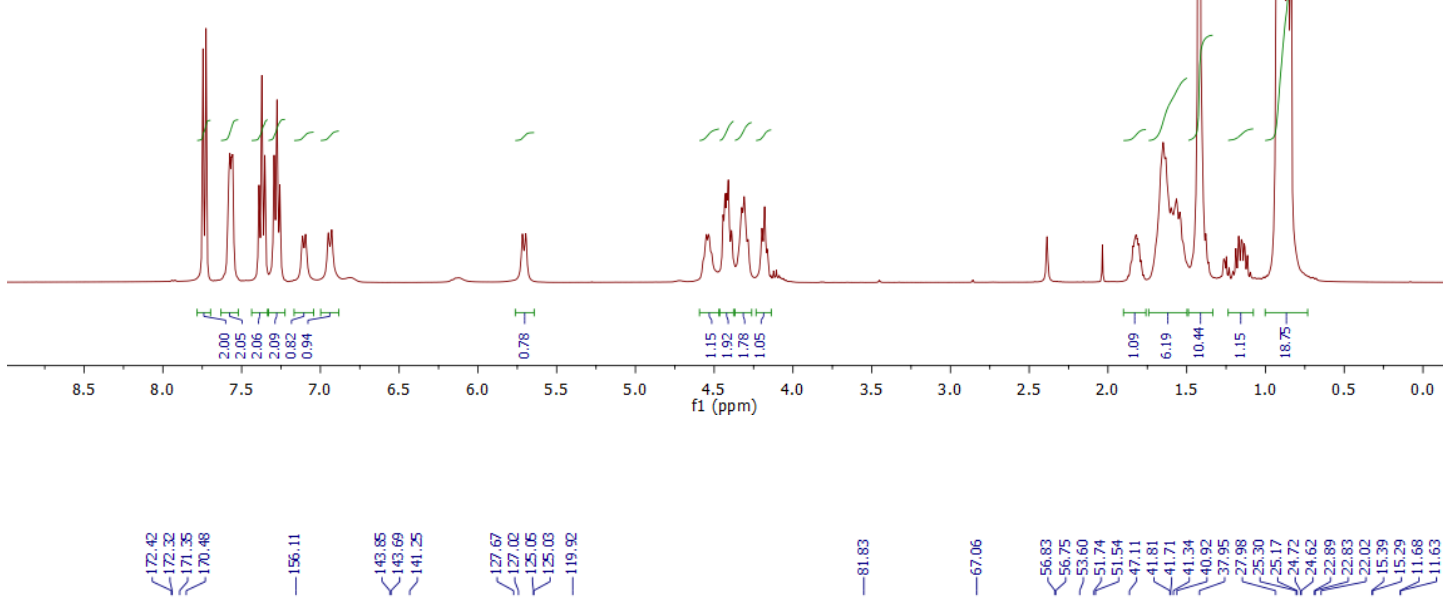<smiles>CC(C)C[C@H](NC(=O)[C@H](CC(C)C)NC(=O)[C@H](NC(=O)C(C)C)C(C)C)C(=O)O</smiles>

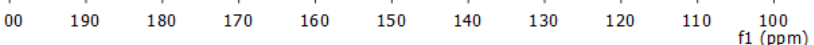


${ }^{1} \mathrm{H}$ NMR and ${ }^{13} \mathrm{C}$ NMR spectra of macrocycle $14\left(600 \mathrm{MHz}, \mathrm{CDCl}_{3}\right)$
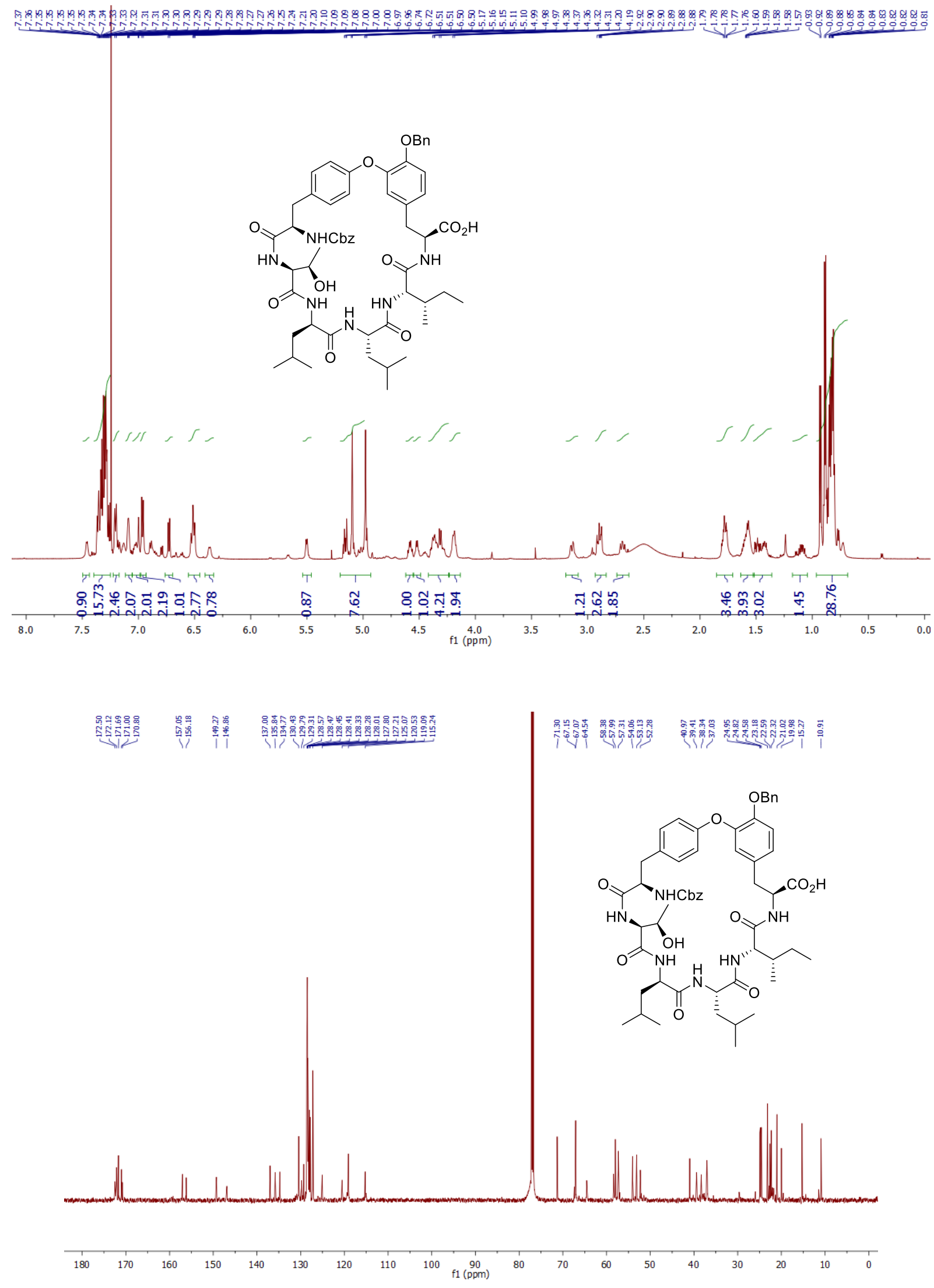
${ }^{1} \mathrm{H}$ NMR and ${ }^{13} \mathrm{C}$ NMR spectra of Ac-Leu-D-Ala-OMe $\left(600 \mathrm{MHz}, \mathrm{CDCl}_{3}\right)$

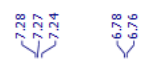<smiles>CC(=O)NC1CC(C)CC(C)C1C(C)O</smiles>

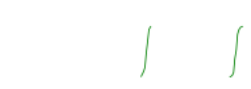

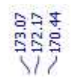<smiles>CC(=O)NC1CC(C)NC1C(C)O</smiles>

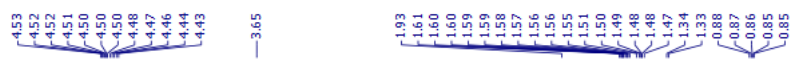

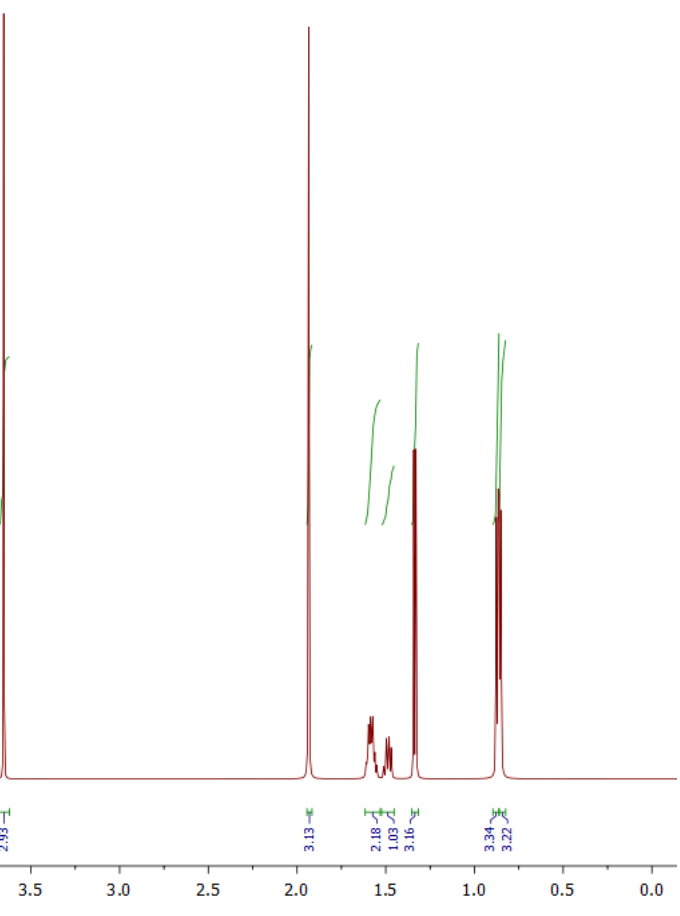

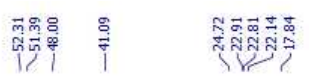

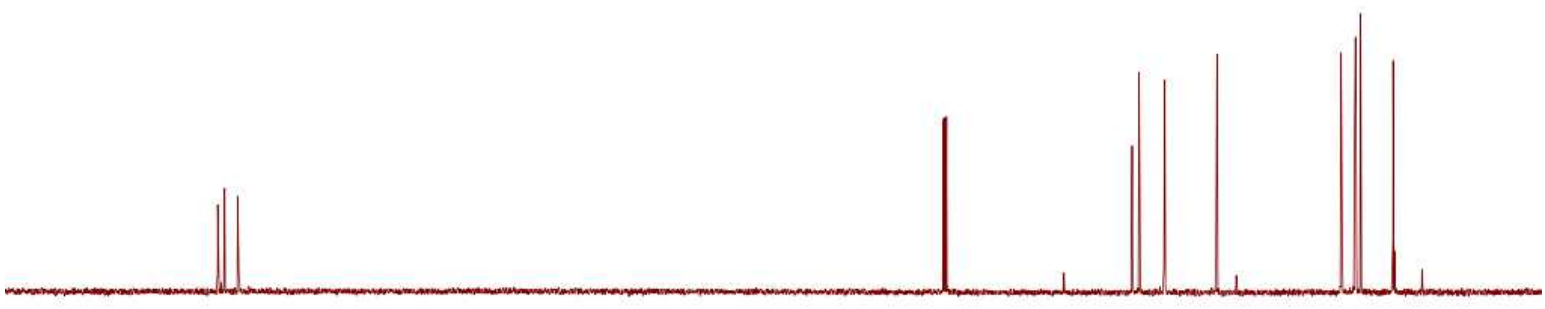

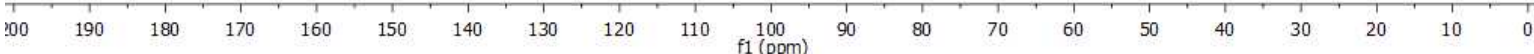


${ }^{1} \mathrm{H}$ NMR and ${ }^{13} \mathrm{C}$ NMR spectra of D-Phe(4-I)-OMe (600 MHz, DMSO- $d_{6}$ )

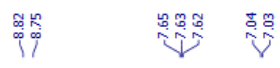

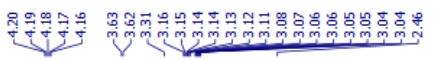
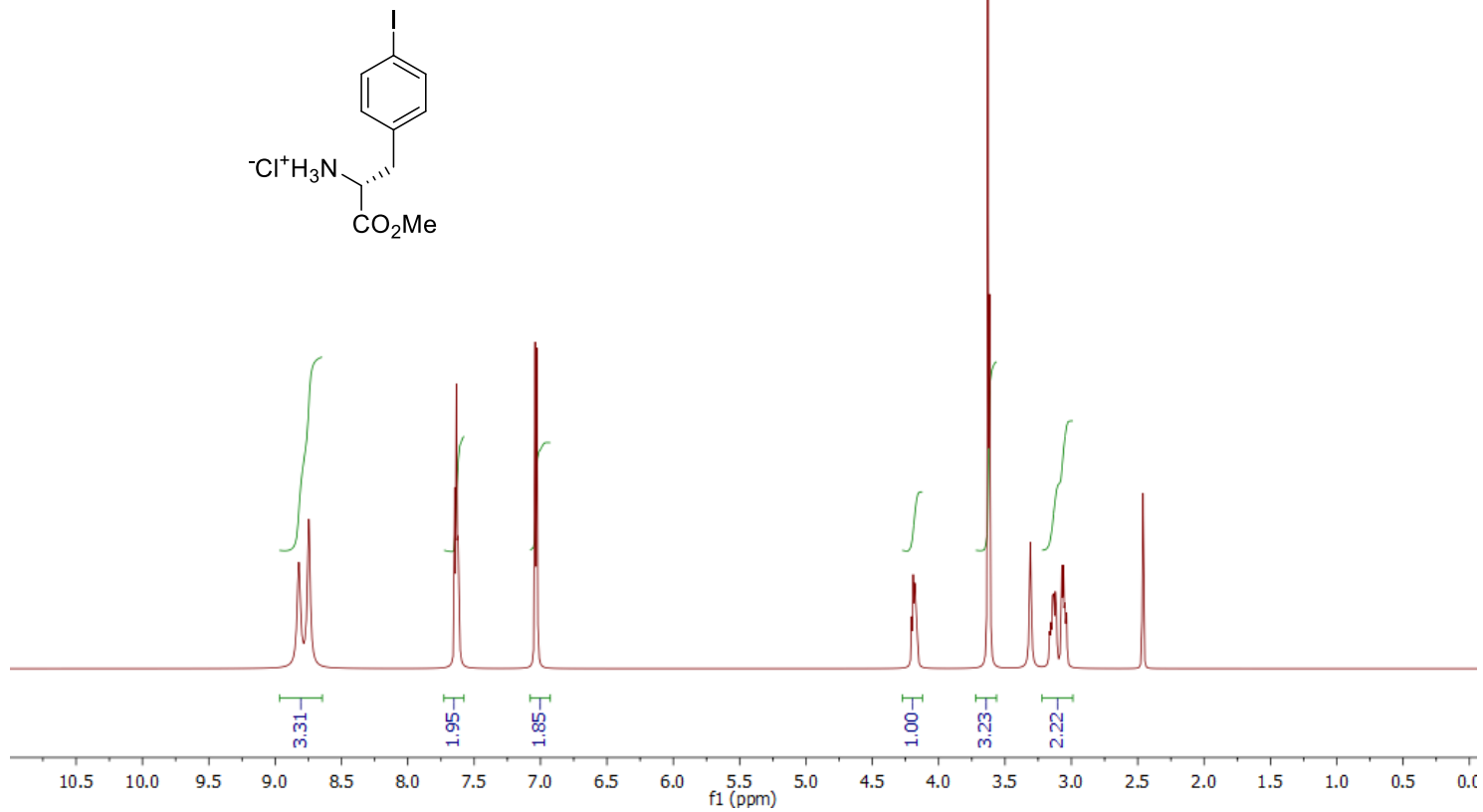

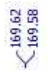

mån

紊

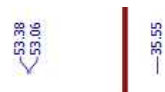<smiles>CC(=O)C(Cc1ccc(I)cc1)N[Cl+3]</smiles>
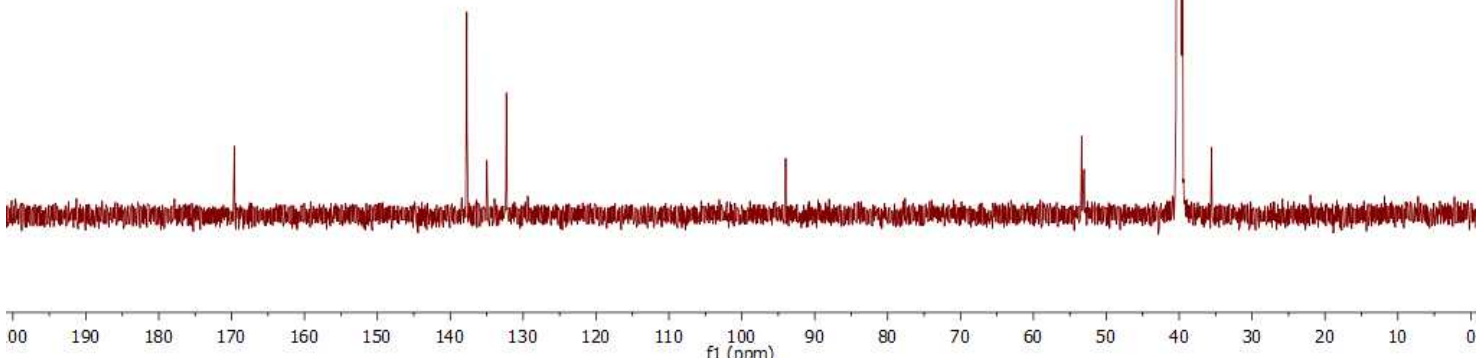
${ }^{1} \mathrm{H}$ NMR and ${ }^{13} \mathrm{C}$ NMR spectra of tripeptide (500 MHz, $\mathrm{CDCl}_{3}$ )

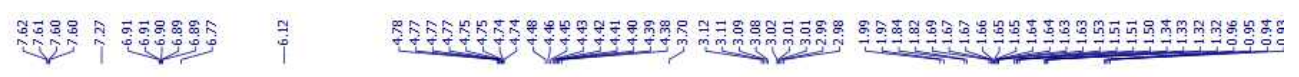<smiles>CC(=O)NC1CC(C)CN(C(=O)C(C)NC(=O)c2ccc(I)cc2)C1=O</smiles>

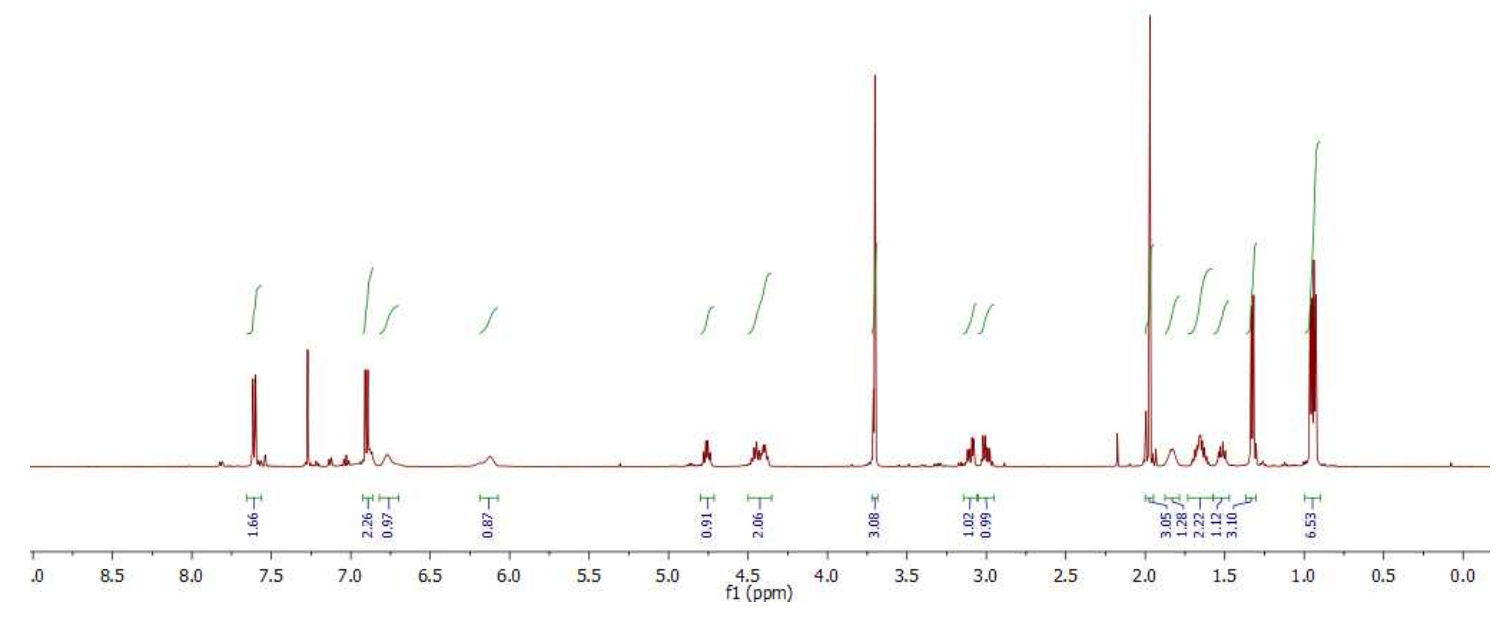

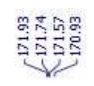

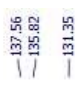

कूँ

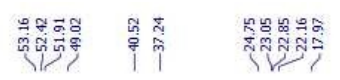<smiles></smiles>

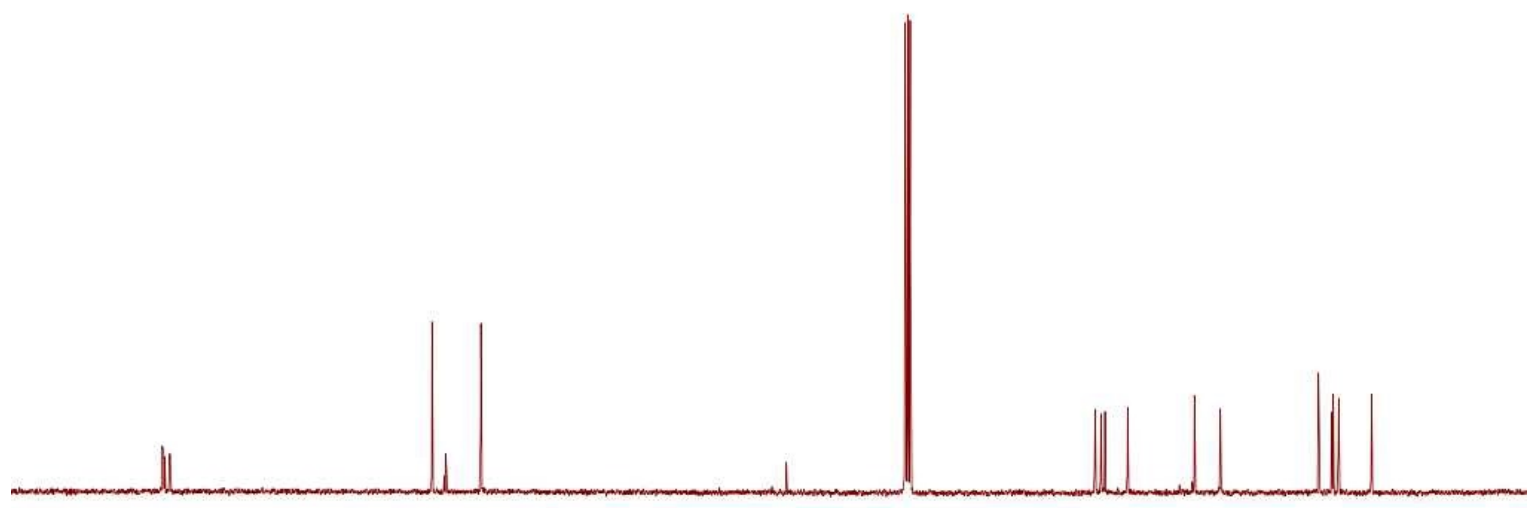

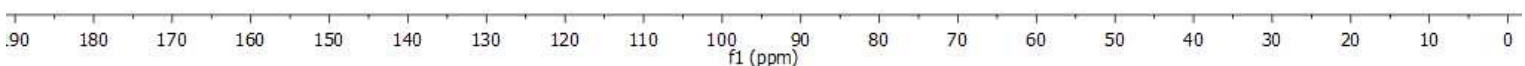


Mass spectrum of tripeptide Ac-Leu-ala-Phe(4-I)-OMe \#30 RT: $0.28 \quad$ AV: 1 NL: $1.76 E 9$
T: FTMS + p ESI Full ms [100.0000-1000.0000]

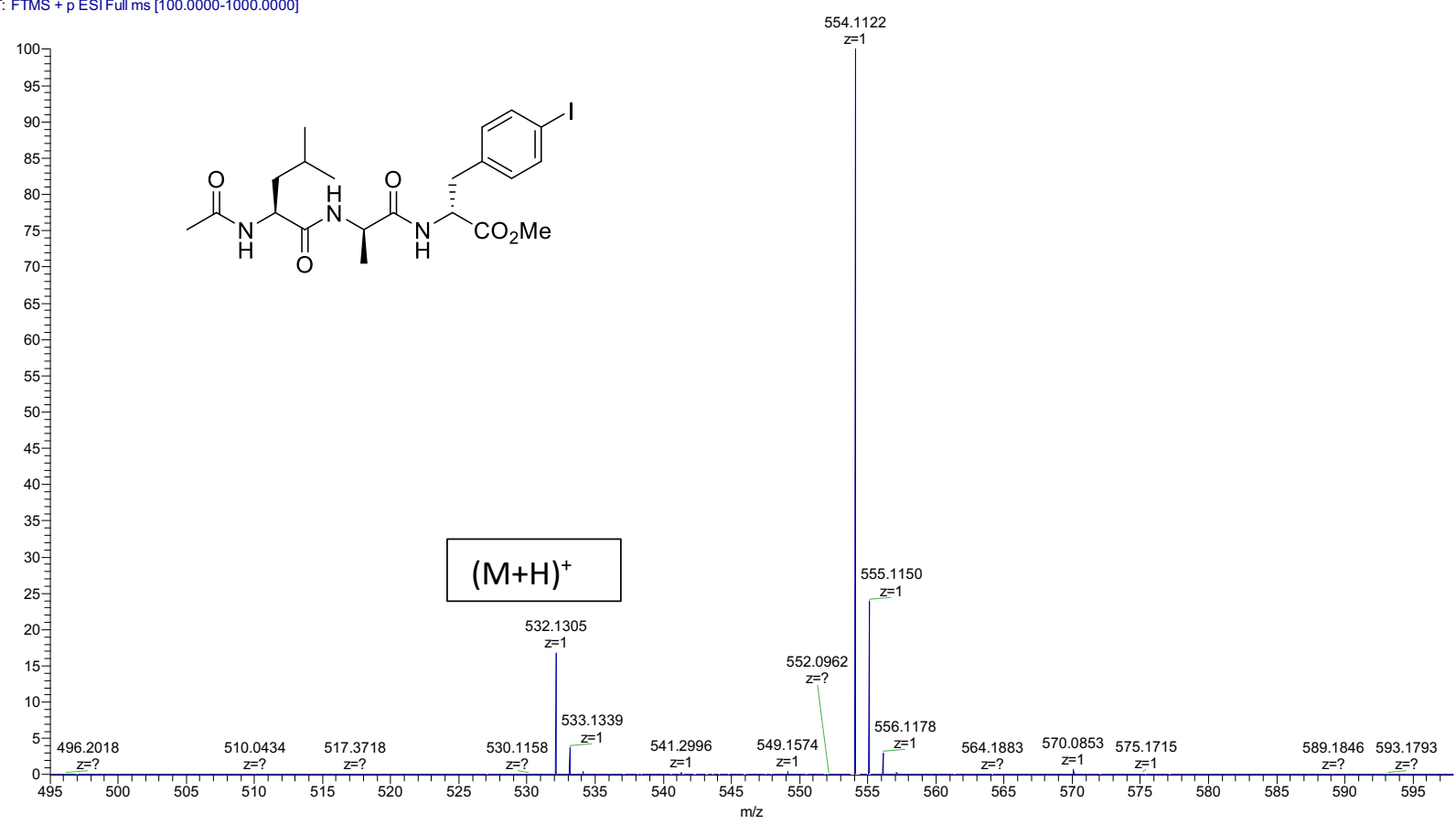

S46 
${ }^{1} \mathrm{H}$ NMR and ${ }^{13} \mathrm{C}$ NMR spectra of Ac-Leu-D-Ala-D-Phe(4-Bpin)-OMe (600 MHz, $\mathrm{CDCl}_{3}$ )

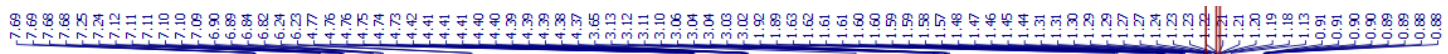<smiles>CC(=O)N[C@@H](CC(C)C)C(=O)N[C@@H](Cc1ccc(B2OC(C)(C)C(C)(C)O2)cc1)C(=O)N[C@@H](C)C(C)=O</smiles>
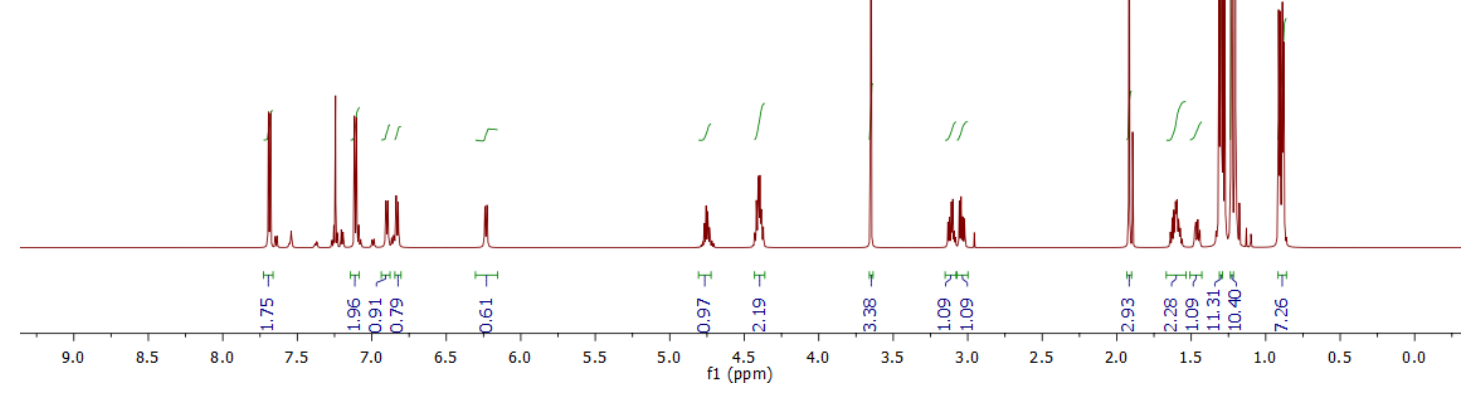

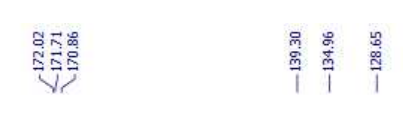<smiles>CC(=O)NC(Cc1ccc(B2OC(C)(C)C(C)(C)O2)cc1)C(=O)NC(C)C(=O)NC(C)C(C)C</smiles>

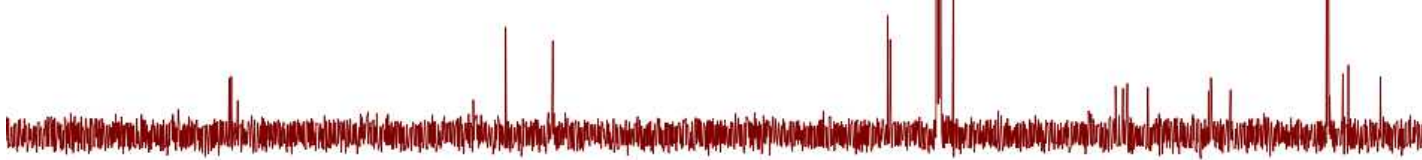

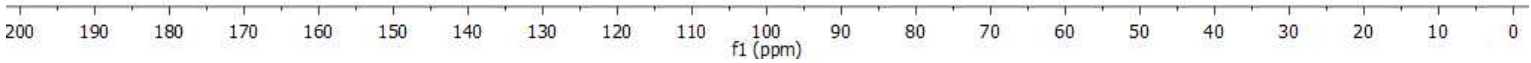


Mass spectrum of Ac-Leu-D-Ala-D-Phe(4-Bpin)-OMe

SH-341-2\#39 RT: 0.36 AV: $1 \quad$ NL: $2.90 \mathrm{Eg}$
T: FTMS + p ESIFull lock ms [100.0000-1000.

$(\mathrm{M}+\mathrm{Na})^{+}$

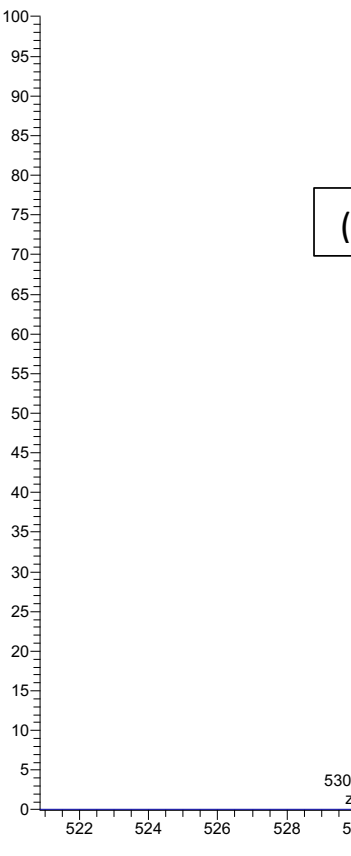

554.3009

$(\mathrm{M}+\mathrm{H})^{+}$

s22.3192

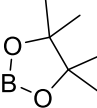

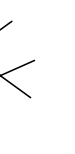

$\operatorname{lin}^{z=1}$

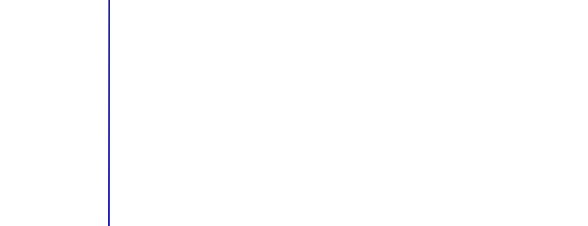

$531.3222 \underset{z=1}{533.3217}$

530.3033
$z=?$$\quad z^{534.3244} 536.2897$

543.8061

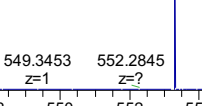

$\mathrm{m} / \mathrm{z}$ 
Mass spectrum of crude linear peptide 20

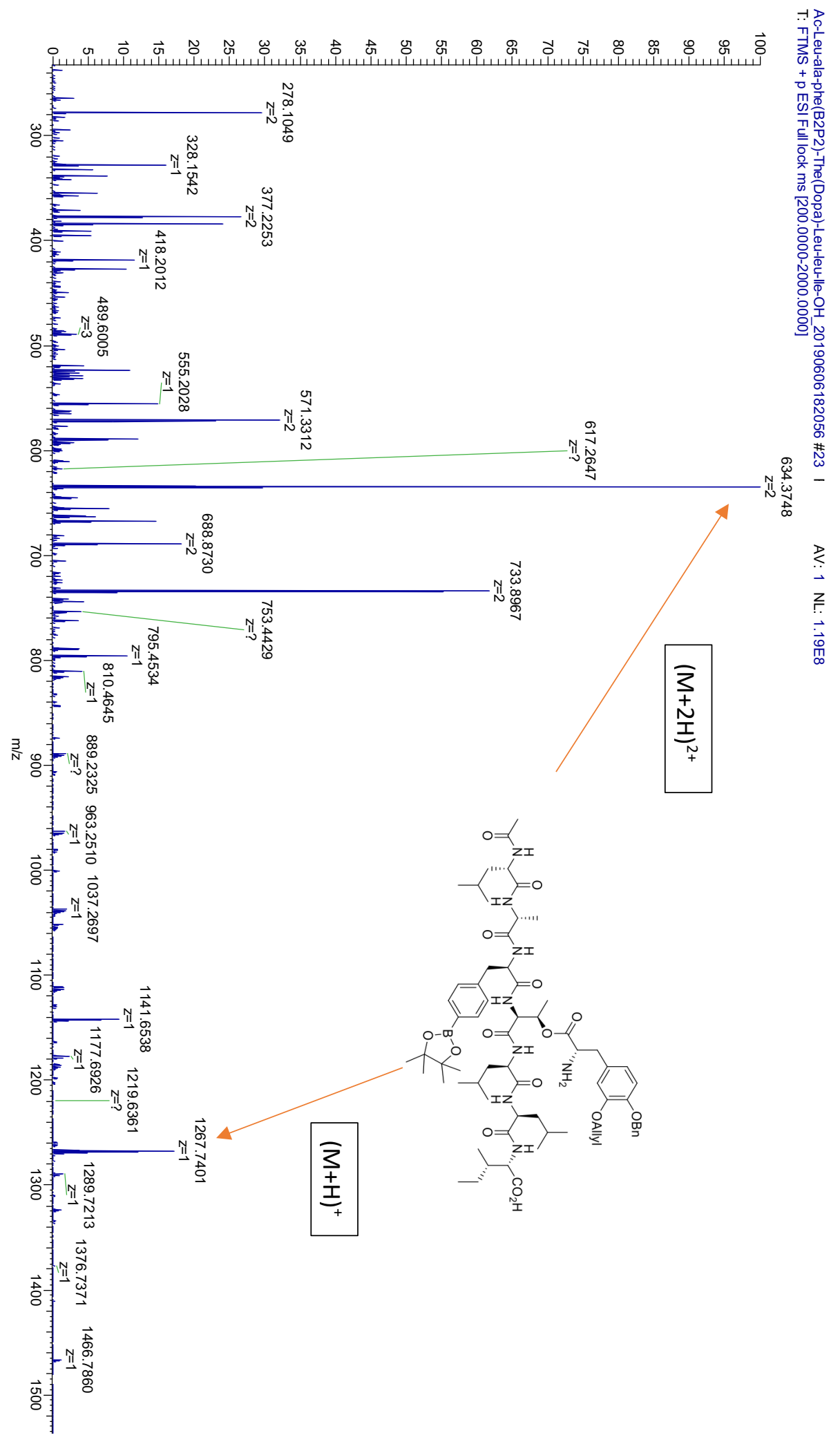


Mass spectrum of linear peptide $\mathbf{2 0}$ after HPLC purification, highlighting protodeborylation byproduct
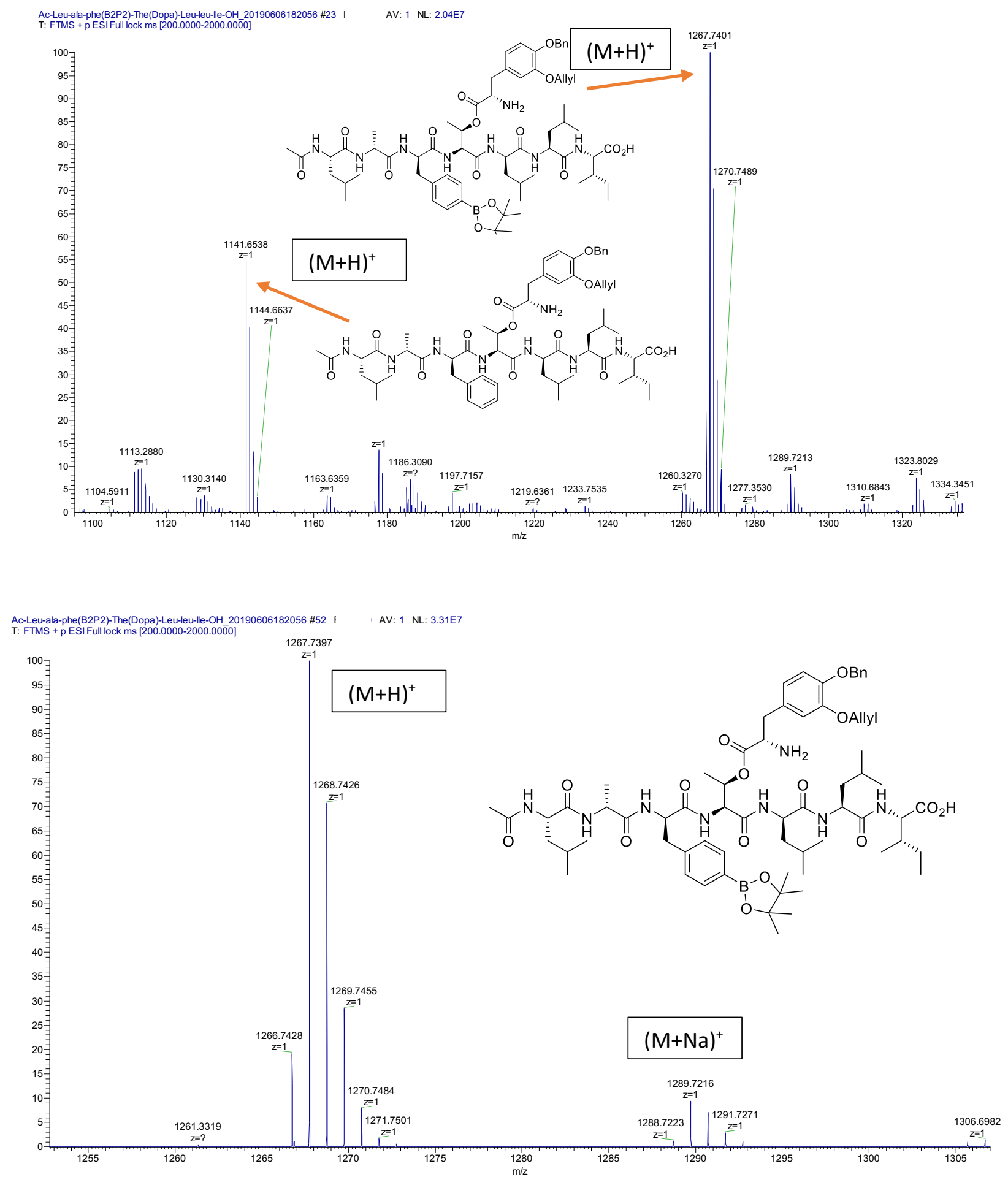
Mass spectrum of cyclic peptide 21
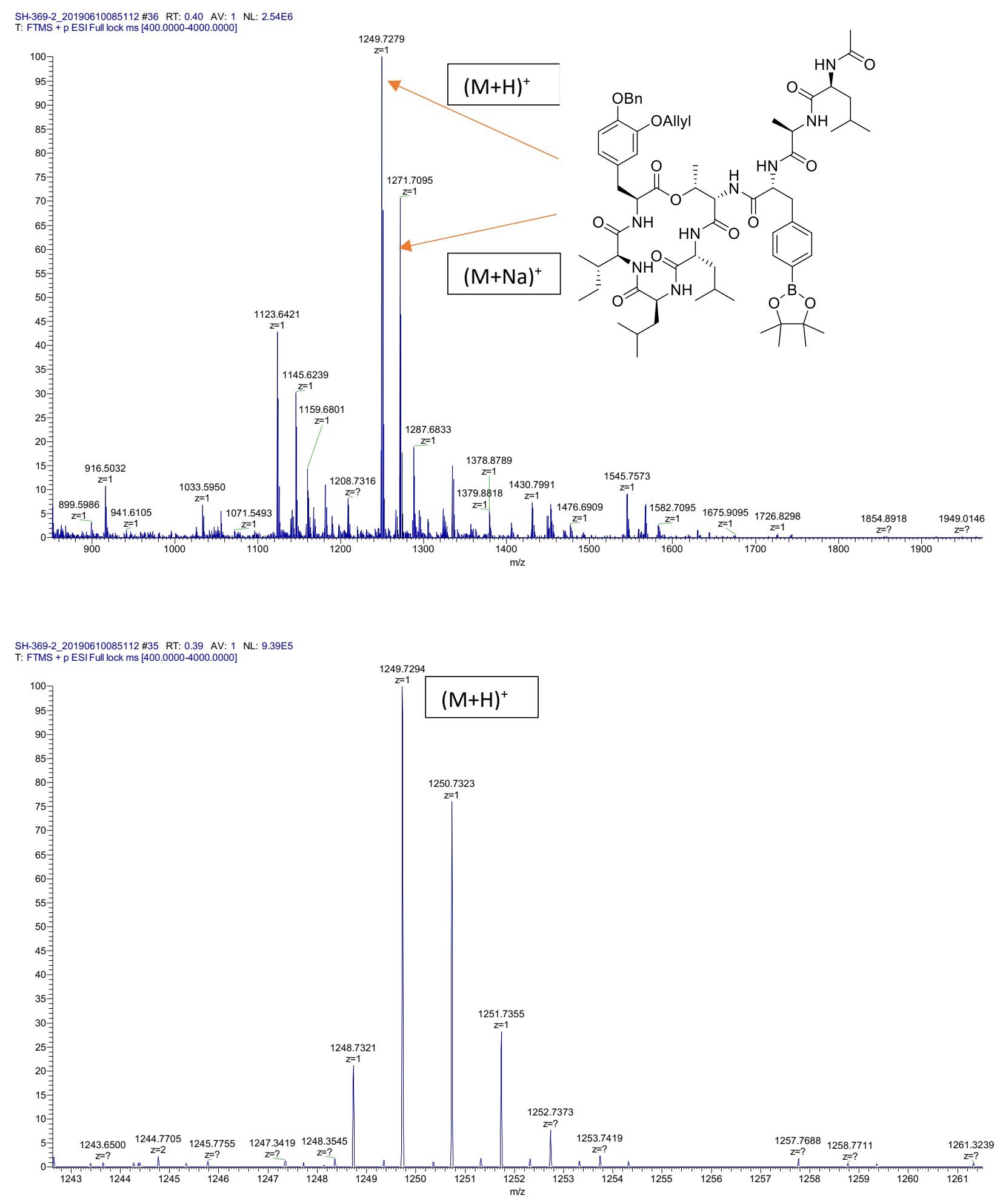
Mass spectrum of allyl deprotected peptide

SH-370\#37 RT: $0.36 \quad$ AV: $1 \quad$ NL: $2.30 E 7$
T: FTMS + p ESI Full ms [200.0000-2000.0000]

$(\mathrm{M}+\mathrm{H})^{+}$

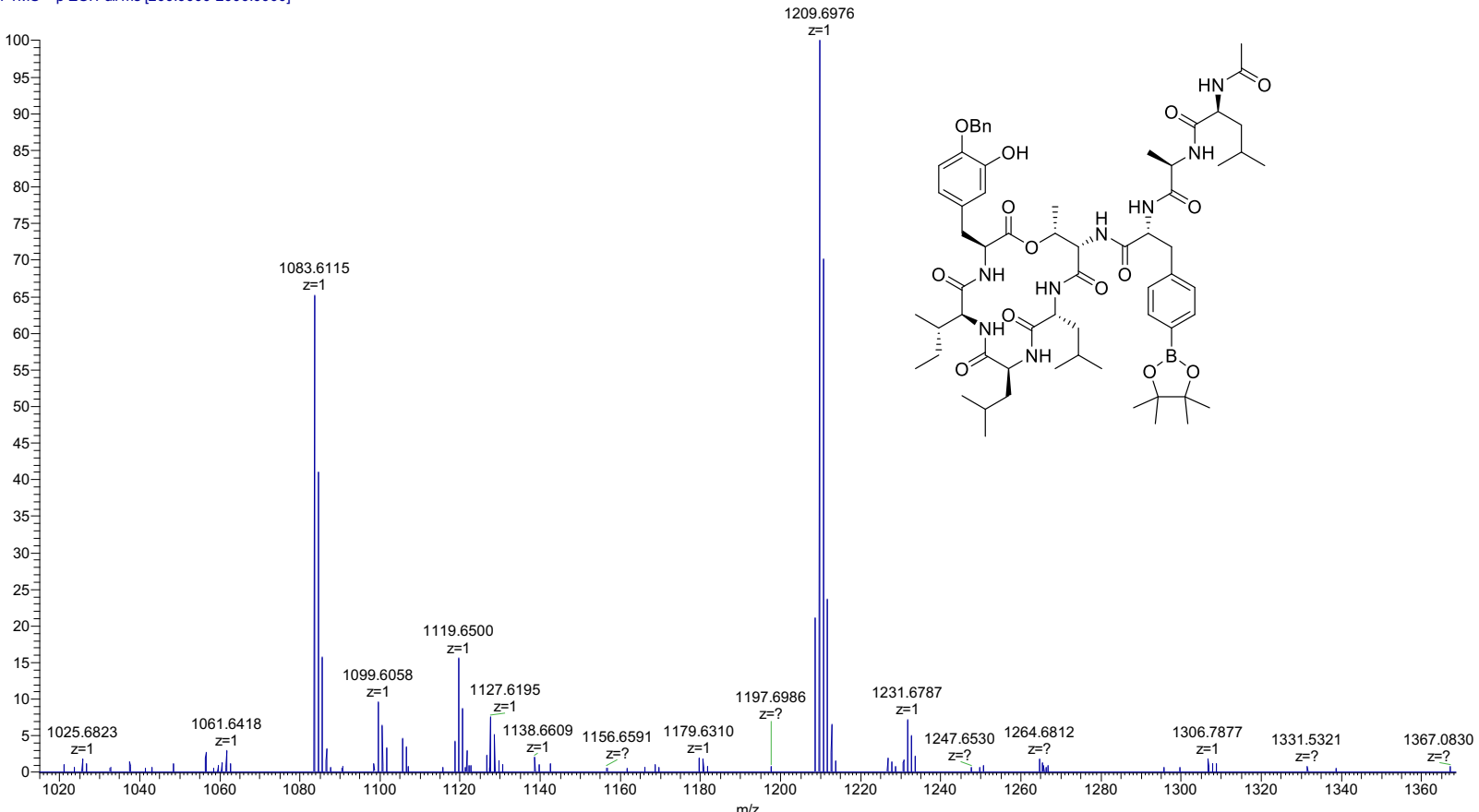

SH-370\#37 RT: 0.36 AV: $1 \quad$ NL: $2.30 E 7$
T: FTMS + p ESIFull ms [200.0000-2000.0000

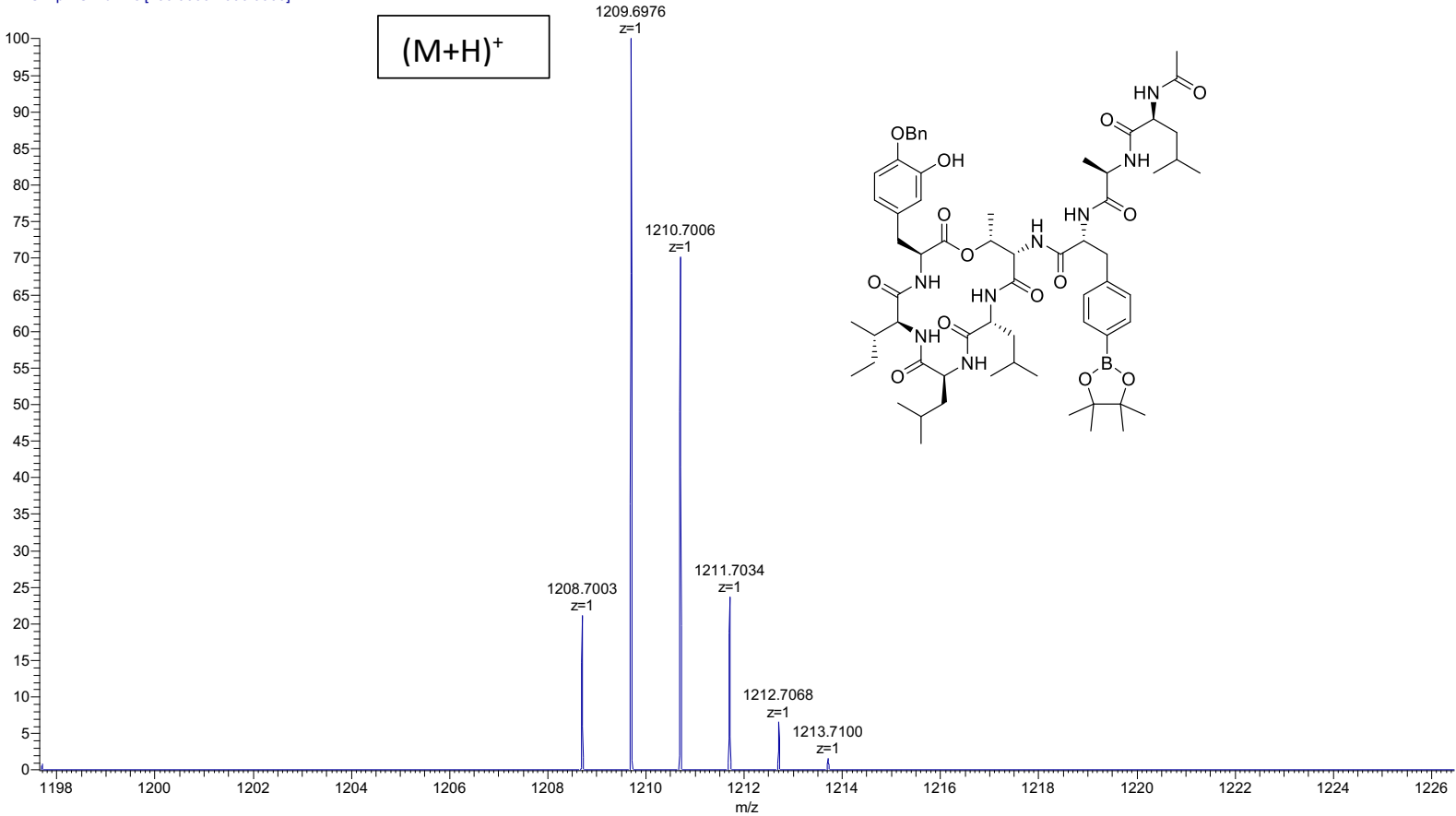




\section{Mass spectrum of peptide $\mathbf{2 2}$}
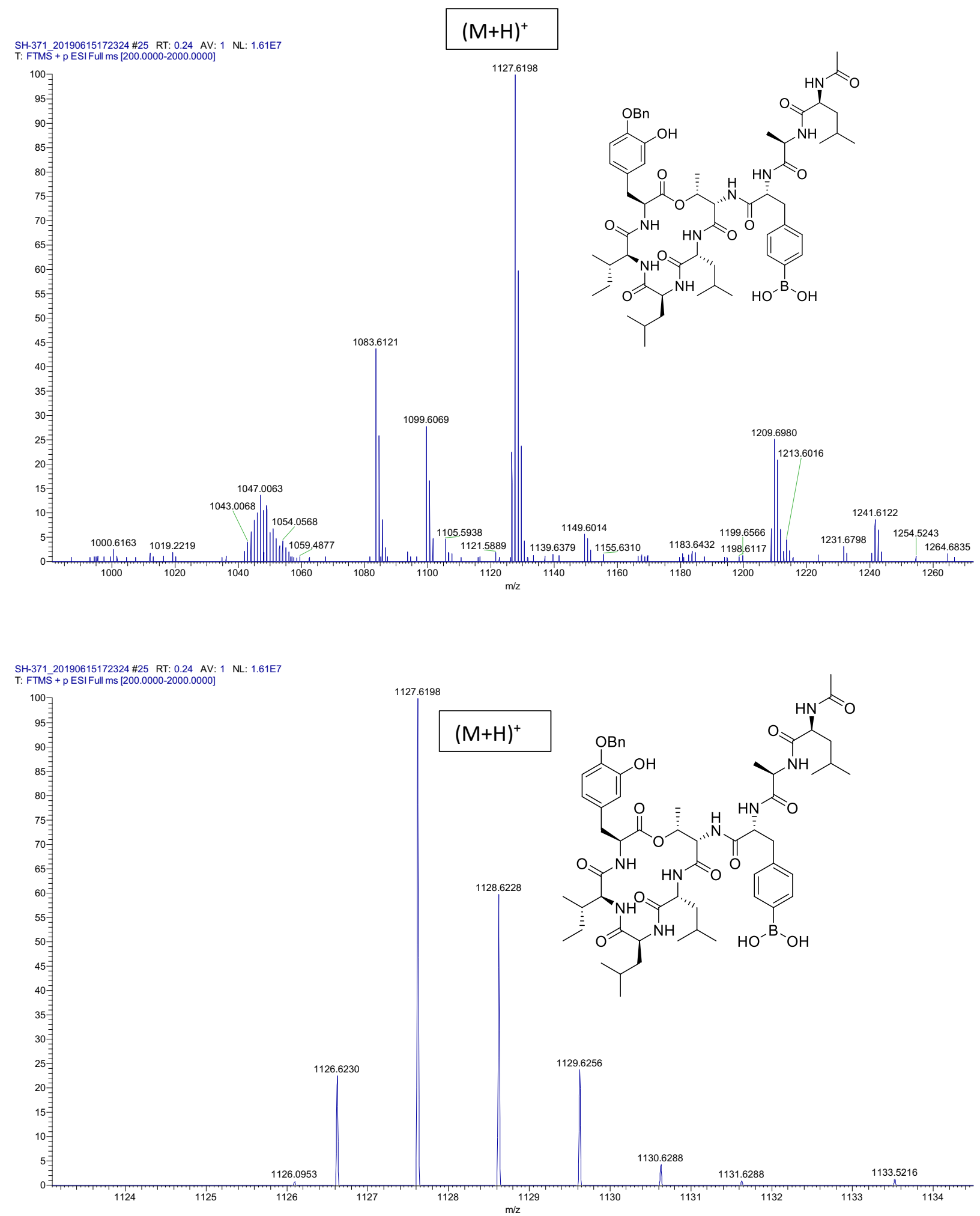
${ }^{1} \mathrm{H}$ NMR and ${ }^{13} \mathrm{C}$ NMR spectra of compound $23\left(500 \mathrm{MHz}, \mathrm{CDCl}_{3}\right)$

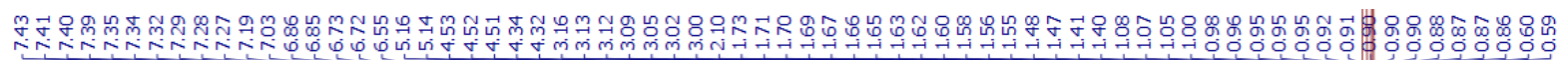

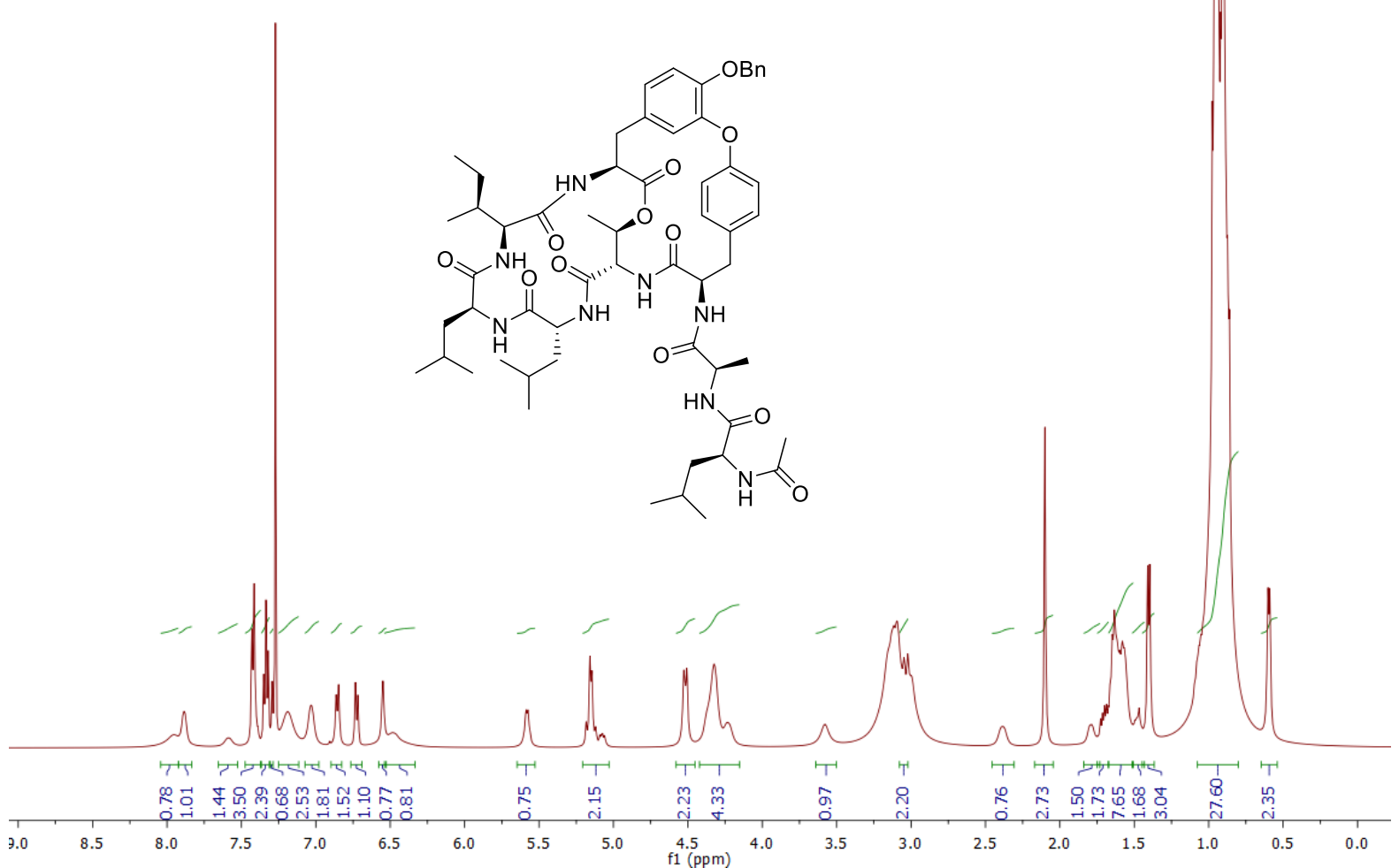

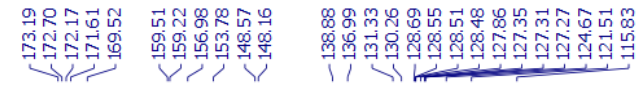

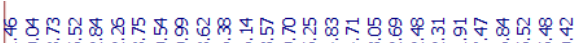

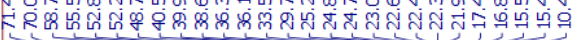

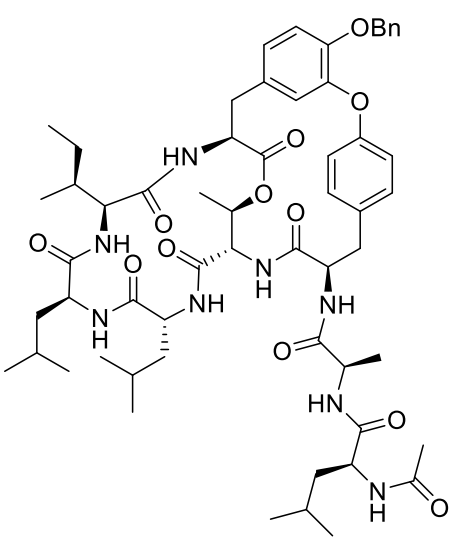
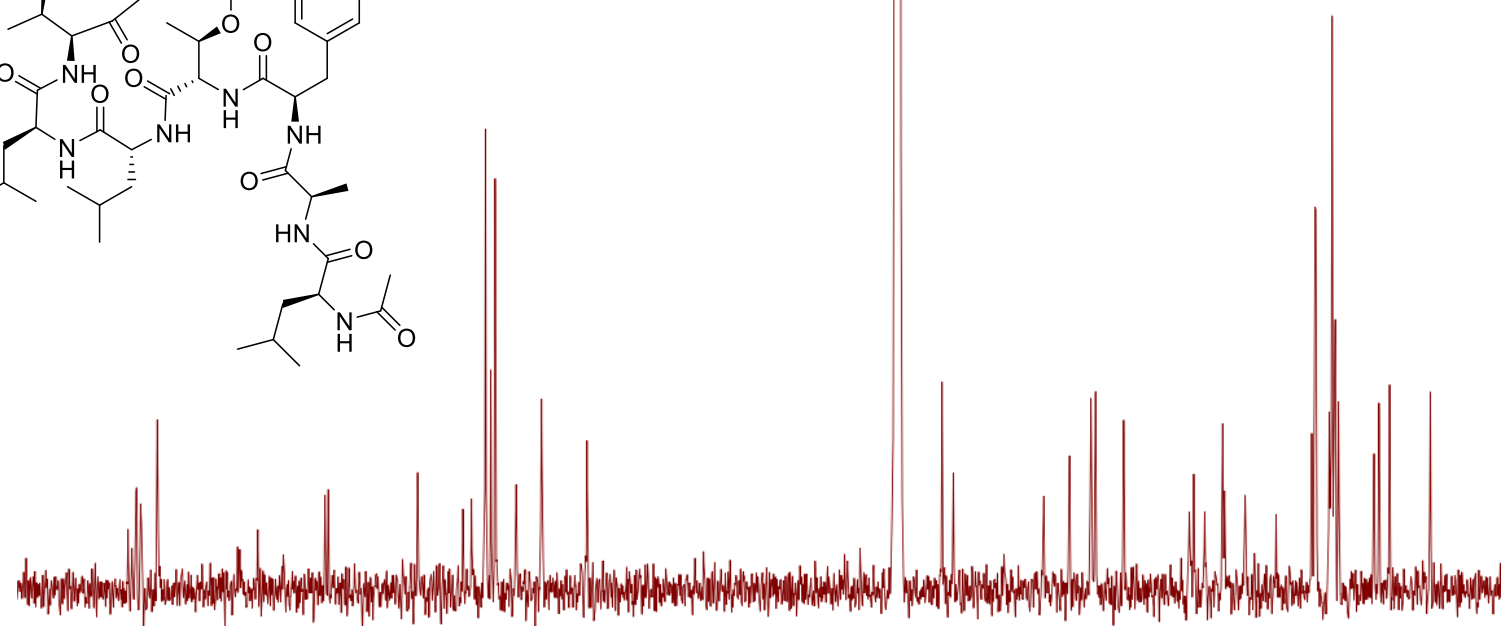

$\begin{array}{lllllllll}180 & 170 & 160 & 150 & 140 & 130 & 120 & 110 & 100 \\ \mathrm{f} 1(\mathrm{ppm}) & 90\end{array}$ 
gCOSY spectrum of compound $23\left(500 \mathrm{MHz}, \mathrm{CDCl}_{3}\right)$

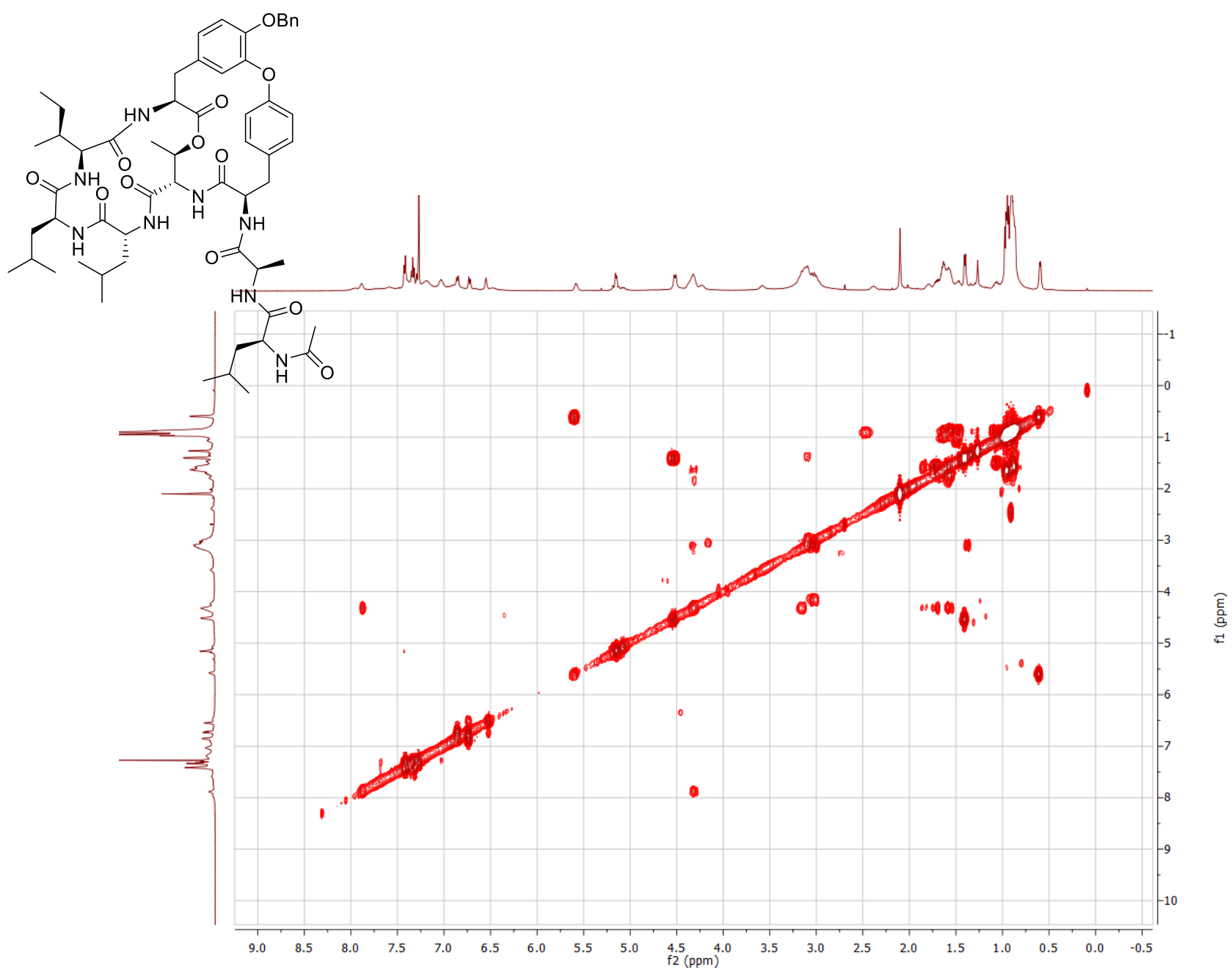

HPLC trace of compound $\mathbf{2 3}$

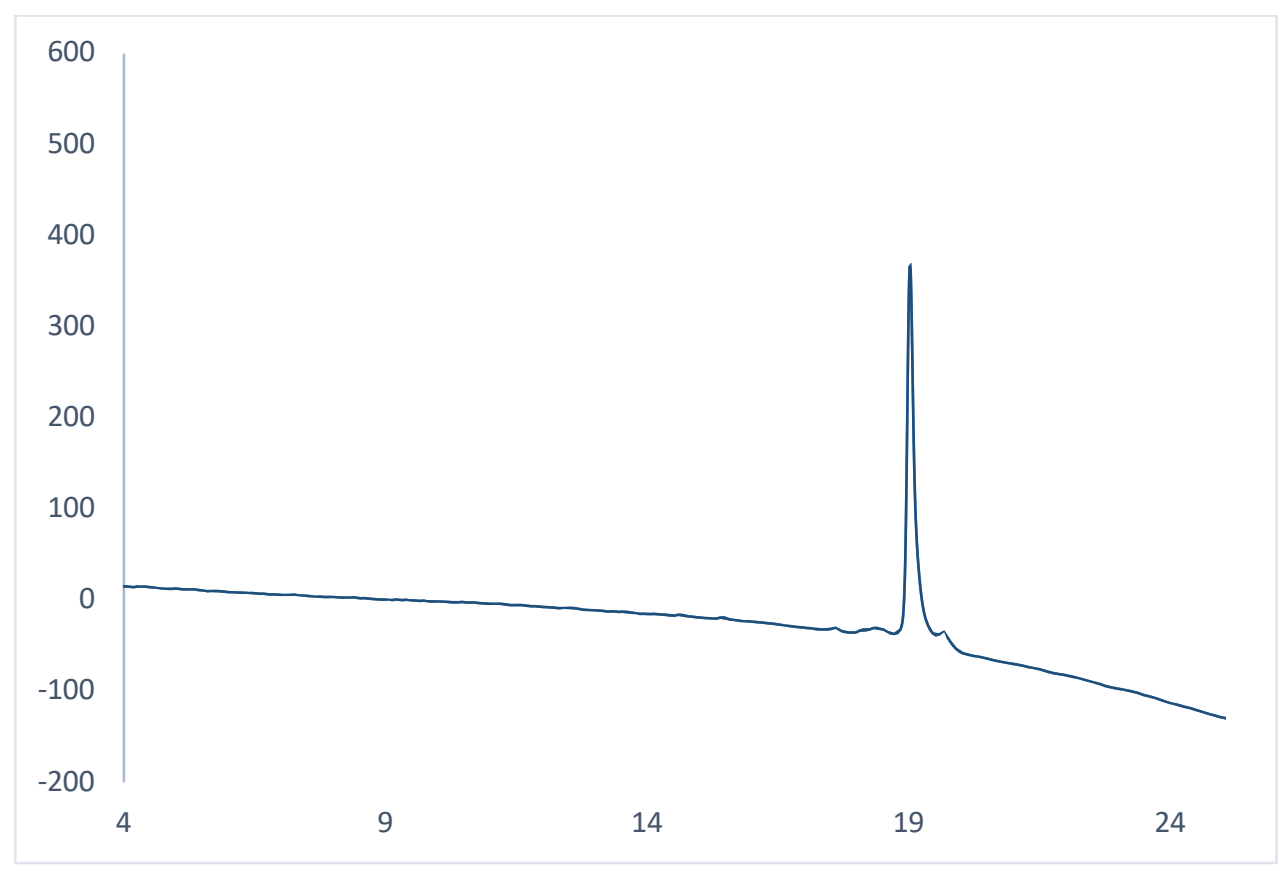


Mass spectrum of bicyclic peptide $\mathbf{2 3}$
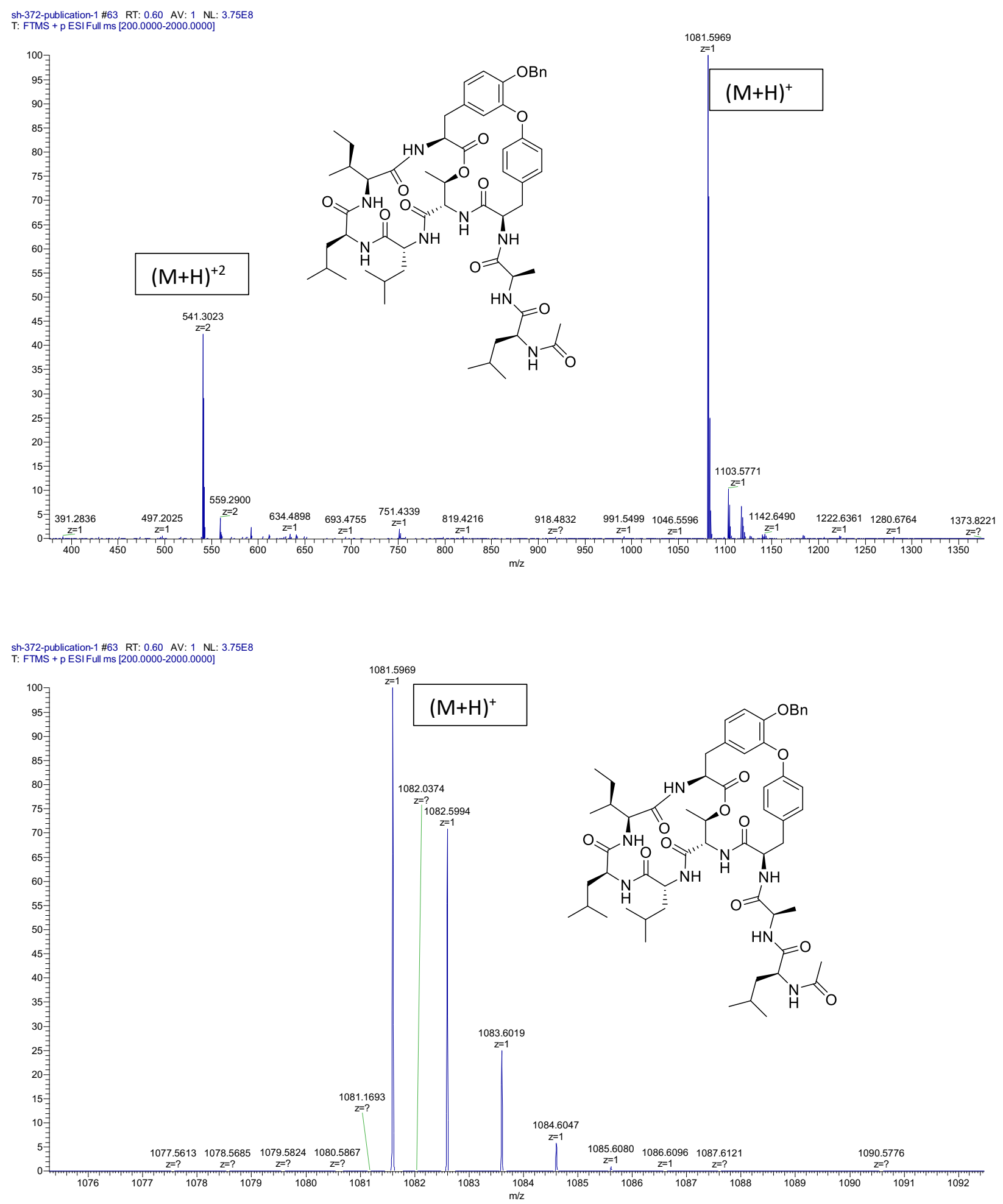
${ }^{1} \mathrm{H}$ NMR and ${ }^{13} \mathrm{C}$ NMR spectra of seongsanamide B $2\left(500 \mathrm{MHz}\right.$, DMSO- $\left.d_{6}\right)$

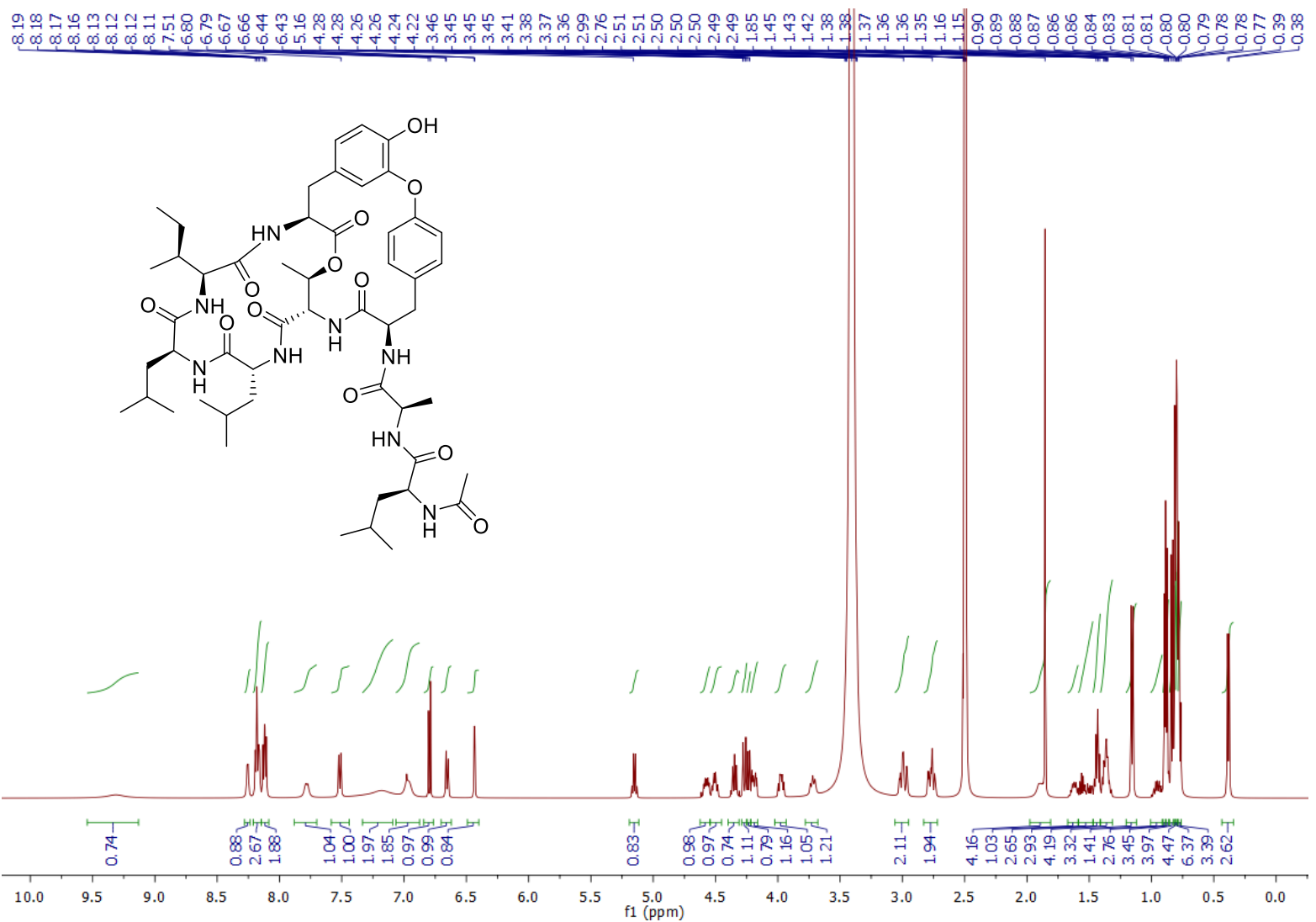

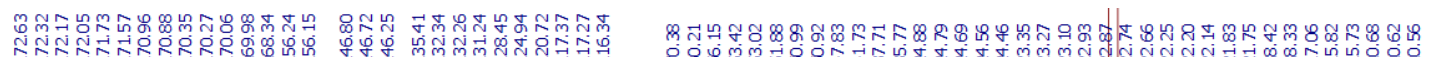

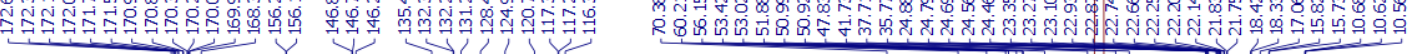

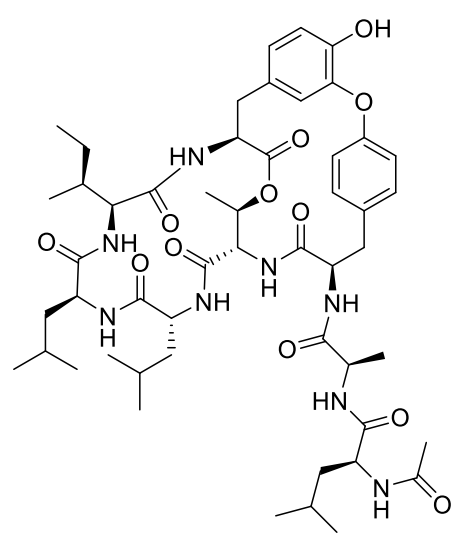

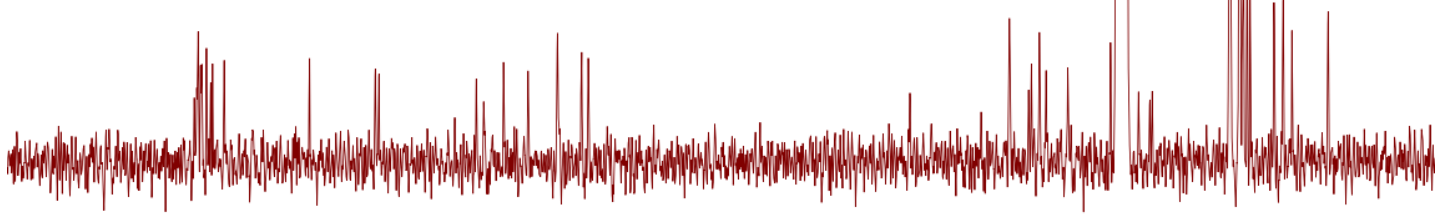

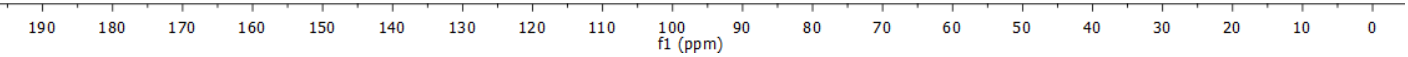


gCOSY spectrum of seongsanamide B 2

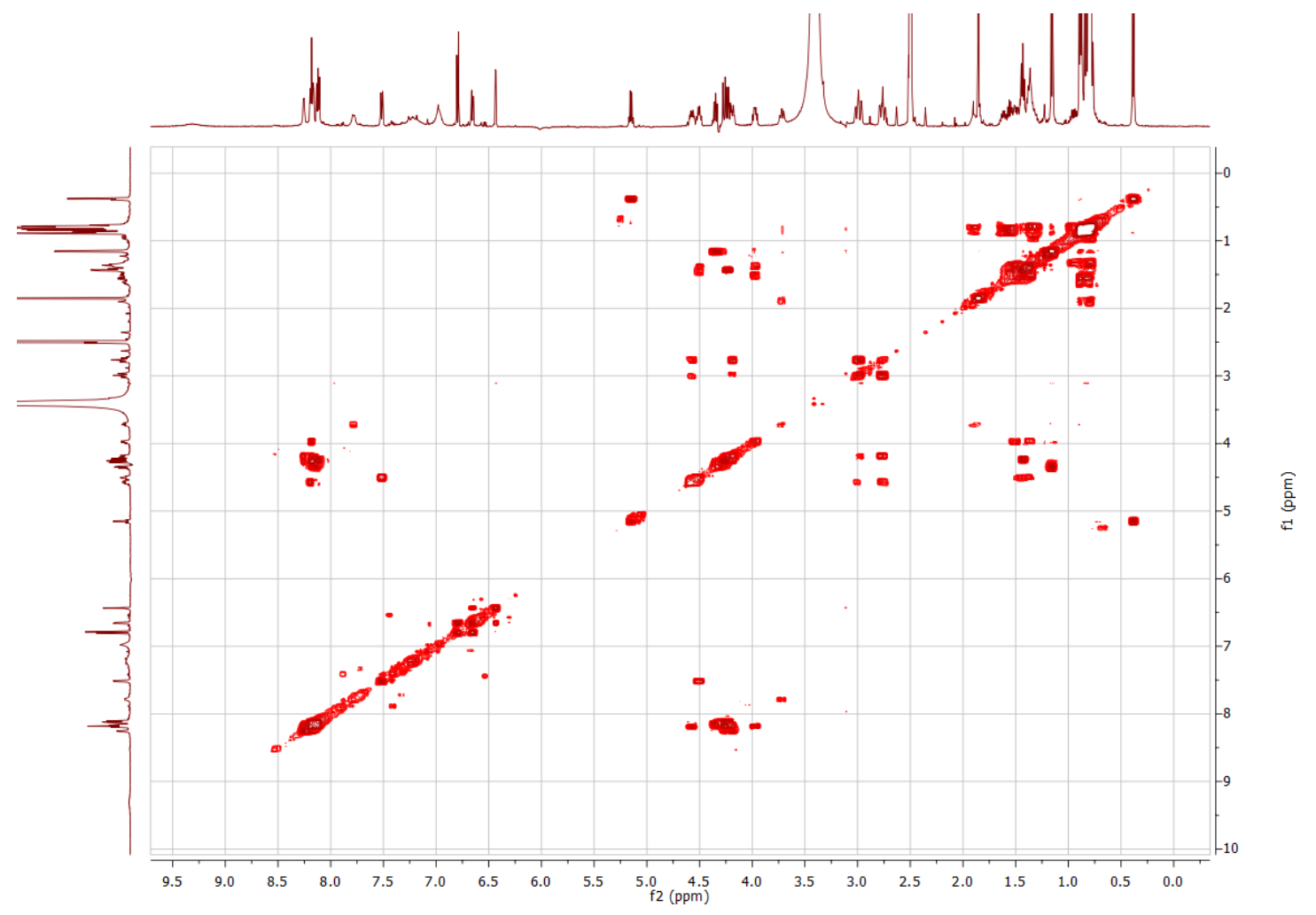

NOESY spectrum of seongsanamide B 2

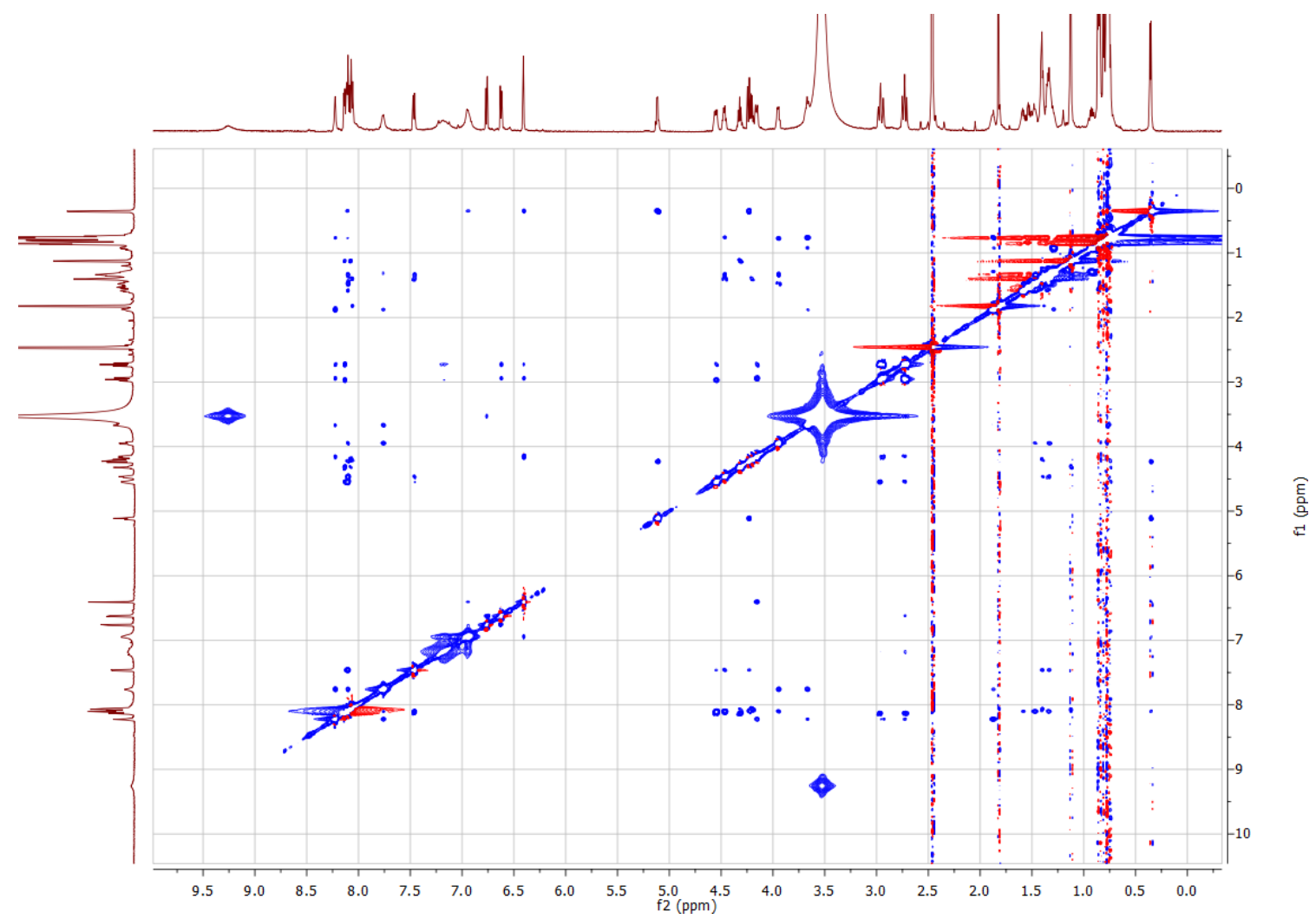


ROESY spectrum of seongsanamide B 2

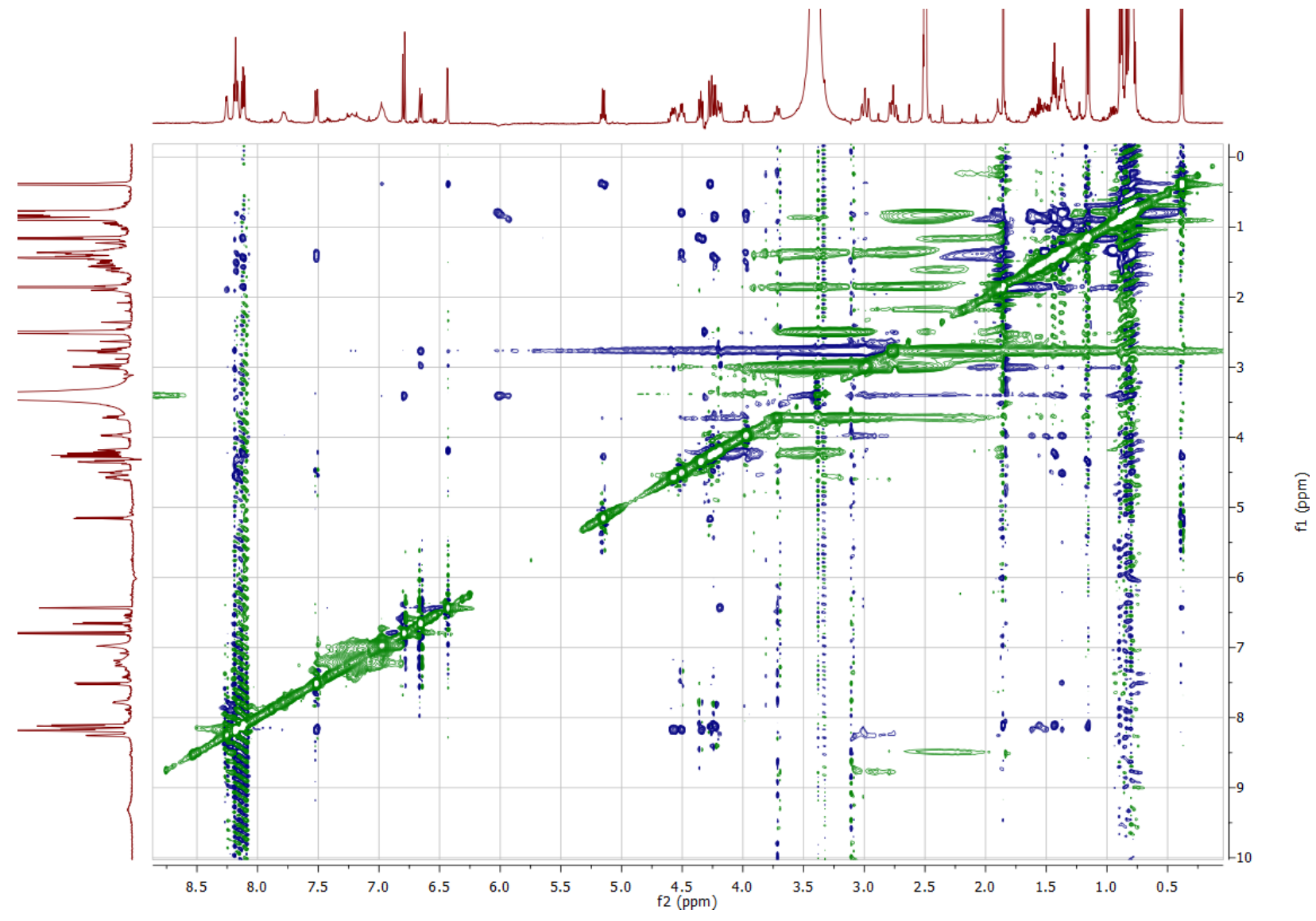

HPLC trace of seongsanamide B 2

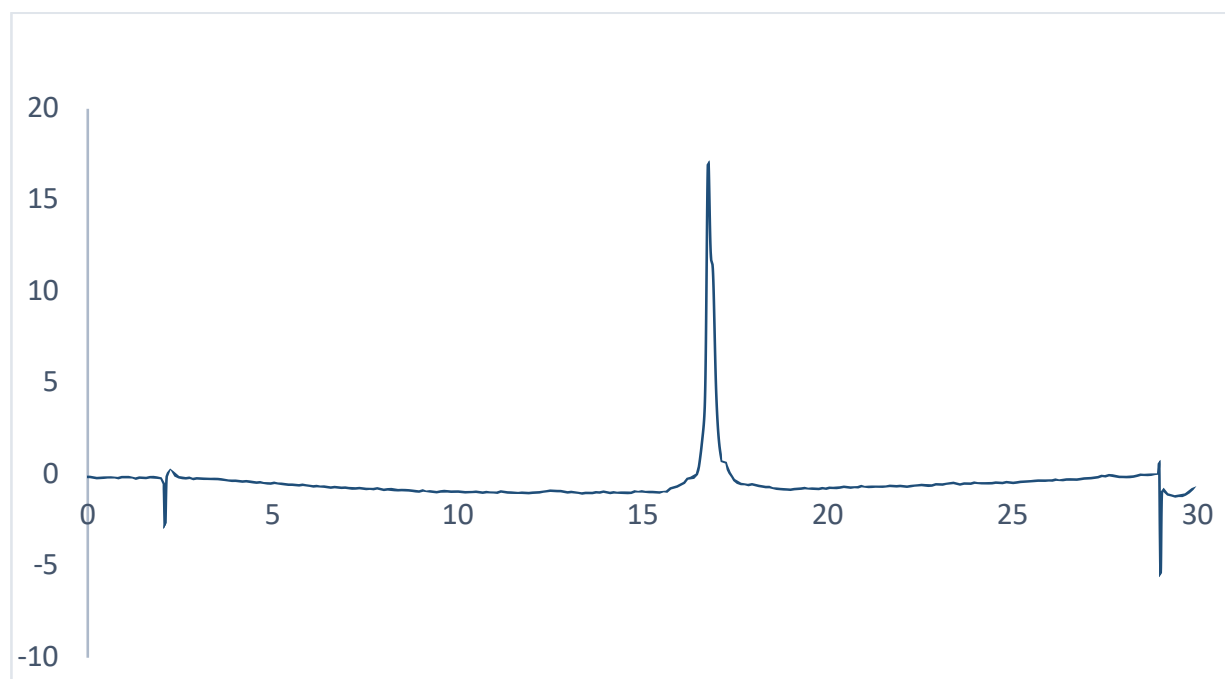


Mass spectrum of seongsanamide B 2

SH-380-PUBLICATION-070719 \#50 RT: 0.50 AV: 1 NL: 1.87E8
T: FTMS + p ESI Full ms [200.0000-2000.0000]

\section{$(\mathrm{M}+\mathrm{H})^{+}$}
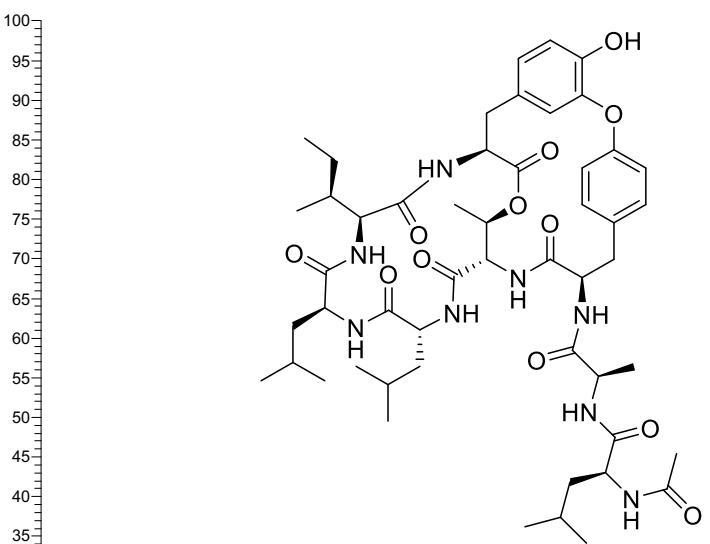

991.5499

40年

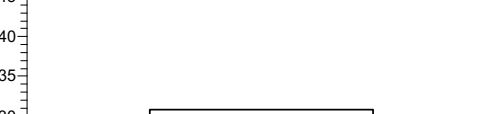

25寻 $\quad(M+2 H)^{2+}$
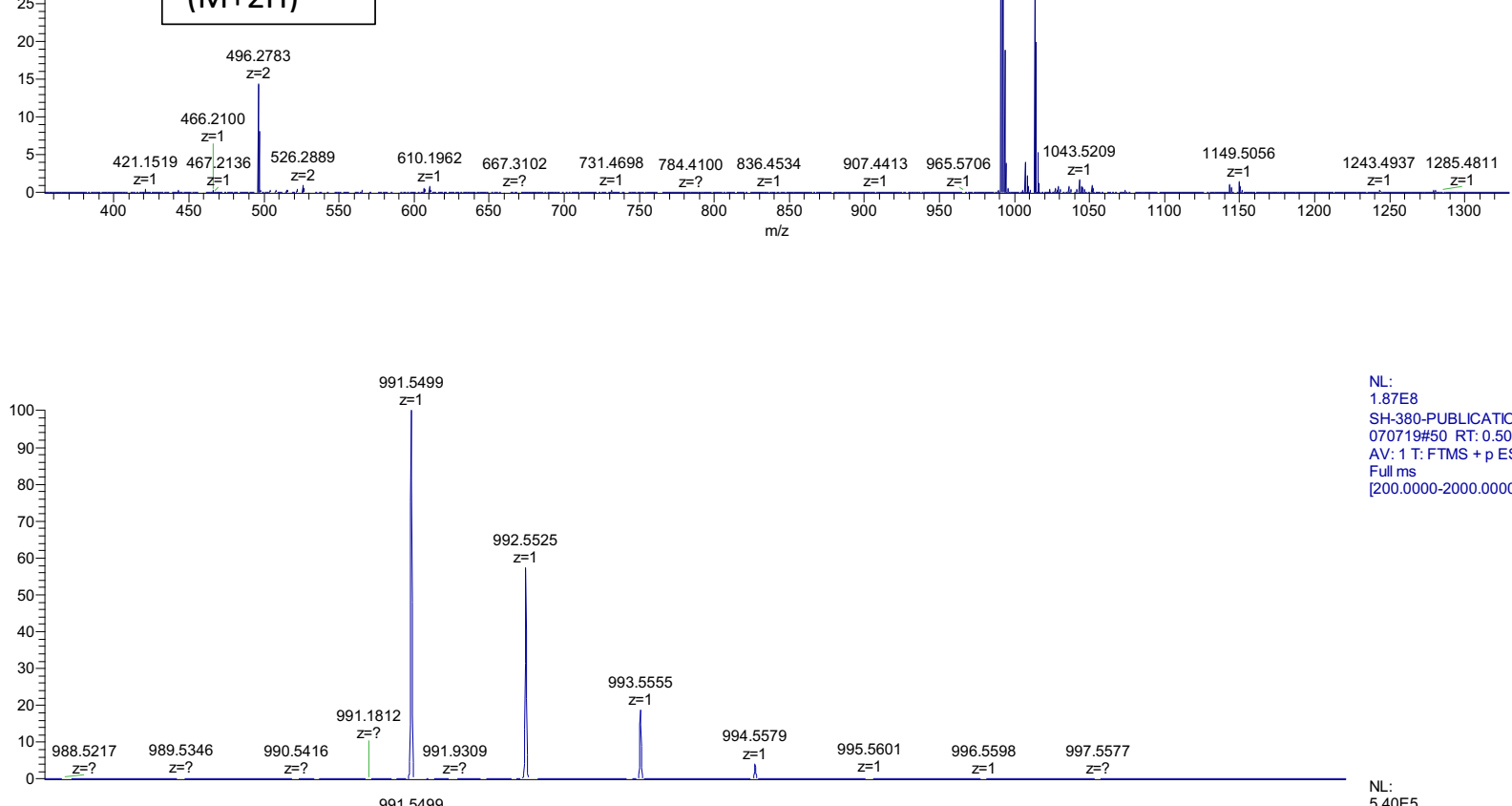

NL:
$1.87 \mathrm{E} 8$

SH-380-PUBLICATION

OTV719\#50 RT: 0.50

Full ms $2000000-2000000]$

[200.0000-2000.0000]

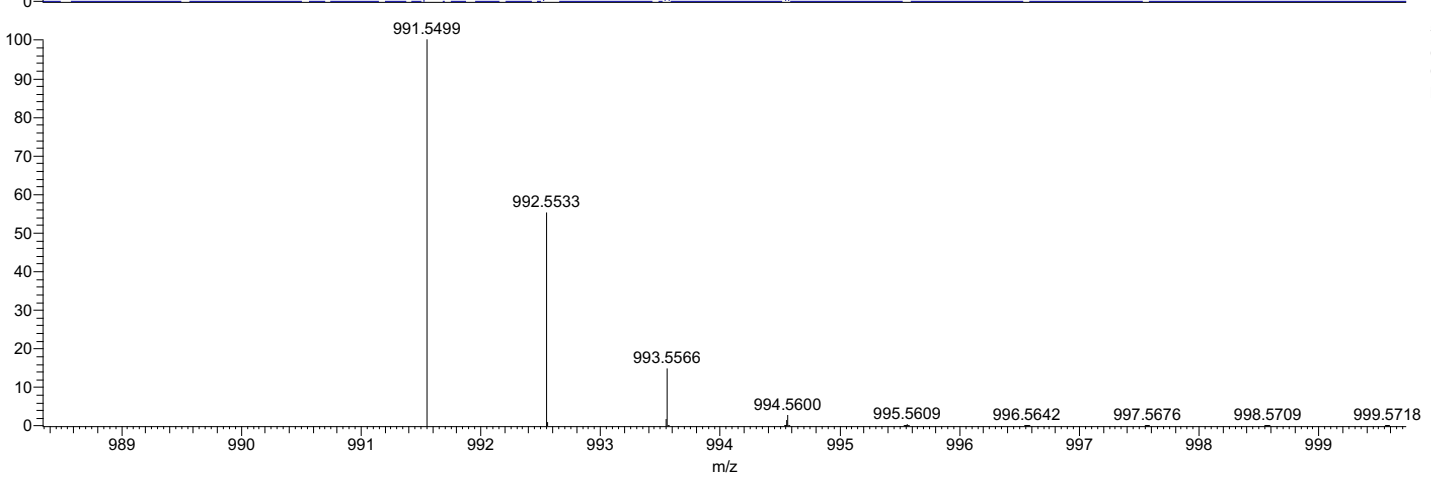

$\mathrm{NL}:$
$5.40 \mathrm{E} 5$

$\mathrm{C}_{51} \mathrm{H}_{75} \mathrm{~N}_{8} \mathrm{O}_{12}:$

pa Chrg 1 
Table S1: ${ }^{1} \mathrm{H}$ NMR and ${ }^{13} \mathrm{C}$ NMR comparison of synthesized 2 and natural product 2.

\begin{tabular}{|c|c|c|c|c|c|c|c|c|c|}
\hline & & \multicolumn{2}{|c|}{ Natural product ${ }^{\mathrm{a}}$} & \multicolumn{2}{|c|}{ Reassigned peaks ${ }^{b}$} & \multicolumn{2}{|c|}{ Synthesized } & \multirow[b]{2}{*}{$\Delta \delta_{c}$} & \multirow[b]{2}{*}{$\Delta \delta_{\mathrm{H}}$} \\
\hline \multicolumn{2}{|c|}{ position } & $\delta c$ & $\delta_{\mathrm{H}}$, mult. $(J$, & $\delta c$ & $\delta_{\mathrm{H}}$, mult. $(\mathrm{J}, \mathrm{Hz})$ & $\delta c$ & $\delta_{\mathrm{H}}$, mult. $(J, \mathrm{~Hz})$ & & \\
\hline \multirow[t]{2}{*}{ Acetamide } & 1 & 22.8 & $1.86, \mathrm{~s}$ & & & 22.8 & $1.85, \mathrm{~s}$ & 0.0 & -0.01 \\
\hline & 2 & 169.8 & & & & 170.0 & & 0.2 & \\
\hline \multirow{6}{*}{ Leu-1 } & $\alpha$ & 52.9 & 4.21 & & & 51.9 & 4.21 & -1.0 & 0.00 \\
\hline & $\beta$ & 40.7 & $1.51,1.36$ & & & 40.3 & $1.53,1.33$ & -0.4 & $0.02,-0.03$ \\
\hline & $\gamma$ & 24.0 & $1.59, \mathrm{~m}$ & & & 24.5 & $1.58, \mathrm{~m}$ & 0.5 & -0.01 \\
\hline & $\delta$ & 22.7 & 0.81 & & & 21.8 & $0.81, d(6.6)$ & -0.9 & 0.00 \\
\hline & $\delta^{\prime}$ & 22.2 & 0.90 & & & 22.2 & 0.86 & 0.0 & -0.04 \\
\hline & $\mathrm{CO}$ & 171.8 & & & & 172.1 & & 0.3 & \\
\hline \multirow{4}{*}{ Ala-2 } & $\mathrm{NH}$ & & 8.14 & & & & 8.13 & & -0.01 \\
\hline & $\alpha$ & 47.7 & $4.37, \mathrm{q}(7.3)$ & & & 47.8 & $4.36(\mathrm{~m})$ & 0.1 & -0.01 \\
\hline & $\beta$ & 18.3 & $1.16 \mathrm{~d}(7.1)$ & & & 18.4 & $1.16 \mathrm{~d}(7.0)$ & 0.1 & 0.00 \\
\hline & $\mathrm{CO}$ & 171.8 & & & & 171.7 & & -0.1 & \\
\hline \multirow{9}{*}{ Tyr-3 } & $\mathrm{NH}$ & & 8.23 & & & & 8.19 & & -0.04 \\
\hline & $\alpha$ & 55.3 & $4.58, \mathrm{~m}$ & & & 56.2 & $4.58, \mathrm{~m}$ & 0.9 & 0.00 \\
\hline & $\mathrm{C} 1$ & 130.1 & & & & 130.1 & & 0.0 & \\
\hline & $\mathrm{C} 2$ & $129.8^{b}$ & 7.03, brs $^{b}$ & - & $7.15, \mathrm{brs}$ & 131.2 & $7.15, \mathrm{brs}$ & $n / a^{c}$ & 0.00 \\
\hline & $\mathrm{C3}$ & $124.2^{b}$ & 6.66, brs $^{b}$ & - & 6.95, brs & 120.7 & 6.95, brs & $n / a^{c}$ & 0.00 \\
\hline & $\mathrm{C} 4$ & 156.0 & & & & 156.2 & & 0.2 & \\
\hline & $\mathrm{C} 5$ & $124.2^{b}$ & $6.66, \mathrm{brs}^{\mathrm{b}}$ & - & $6.95, \mathrm{brs}$ & 120.7 & 6.95, brs & $n / a^{c}$ & 0.00 \\
\hline & $\mathrm{C} 6$ & $129.8^{b}$ & 7.03, brs $^{b}$ & - & 7.15, brs & 131.2 & 7.15, brs & $n / a^{c}$ & 0.00 \\
\hline & $\mathrm{CO}$ & 171.4 & & & & 171.6 & & 0.2 & \\
\hline \multirow{5}{*}{ Thr-4 } & $\mathrm{NH}$ & & 8.17 & & & & 8.18 & & 0.01 \\
\hline & $\alpha$ & 55.6 & $4.28, d(10.7)$ & & & 56.1 & $4.28, d(7.6)$ & 0.5 & 0.00 \\
\hline & $\beta$ & 70.4 & $5.16, \mathrm{q}(6.3)$ & & & 70.4 & $5.16, \mathrm{q}(6.7)$ & 0.0 & 0.00 \\
\hline & $\gamma$ & 16.9 & $0.39, \mathrm{~d}(6.5)$ & & & 17.0 & $0.36, \mathrm{dd}(6.6)$ & 0.1 & -0.03 \\
\hline & $\mathrm{CO}$ & 168.0 & & & & 168.0 & & 0.0 & \\
\hline \multirow{5}{*}{ Leu-5 } & $\mathrm{NH}$ & & $7.51, \mathrm{~d}(8.7)$ & & & & $7.47, \mathrm{~d}(8.3)$ & & -0.04 \\
\hline & $\alpha$ & 51.0 & $4.52, \mathrm{~m}$ & & & 50.9 & $4.52, \mathrm{~m}$ & -0.1 & 0.00 \\
\hline & $\beta$ & 41.1 & $1.44,1.36$ & & & 41.7 & $1.40,1.34$ & 0.6 & $-0.04,-0.02$ \\
\hline & $\gamma$ & 24.0 & 1.39 & & & 24.6 & 1.36 & 0.6 & -0.03 \\
\hline & $\mathrm{CO}$ & 171.4 & & & & 171.0 & & -0.4 & \\
\hline \multirow{7}{*}{ Leu-6 } & $\mathrm{NH}$ & & 8.27, brs & & & & $8.26 \mathrm{brs}$ & & -0.01 \\
\hline & $\alpha$ & 52.3 & $3.99, \mathrm{~m}$ & & & 53.4 & $3.98, \mathrm{~m}$ & 1.1 & -0.01 \\
\hline & $\beta$ & 39.6 & $1.53,1.44$ & & & 41.3 & $1.53,1.42$ & 1.7 & $0.00,-0.02$ \\
\hline & $\gamma$ & 23.8 & $1.61, \mathrm{~m}$ & & & 24.5 & 1.58 & 0.7 & -0.03 \\
\hline & $\delta$ & 22.4 & 0.82 & & & 22.7 & 0.81 & 0.3 & -0.01 \\
\hline & $\delta^{\prime}$ & 22.2 & 0.89 & & & 21.8 & 0.88 & -0.4 & -0.01 \\
\hline & $\mathrm{CO}$ & 171.2 & & & & 171.7 & & 0.5 & \\
\hline & $\mathrm{NH}$ & & 7.87, brs & & & & 7.78, brs & & -0.09 \\
\hline & $\alpha$ & 60.1 & $3.73, \mathrm{t}(9.5)$ & & & 60.1 & $3.72, \mathrm{~m}$ & 0.0 & -0.01 \\
\hline $10-7$ & $\beta$ & 34.7 & $1.88, \mathrm{~m}$ & & & 35.7 & 1.87 & 1.0 & -0.01 \\
\hline 11e-/ & $\gamma$ & 22.9 & 1.33, m 0.96, & & & 23.3 & $1.33,0.93$ & 0.4 & $0.00,-0.03$ \\
\hline & $\delta$ & 22.9 & 0.82 & & & 22.9 & 0.81 & 0.0 & -0.01 \\
\hline & $\gamma^{\prime}$ & 15.6 & 0.79 & & & 15.7 & 0.81 & 0.1 & 0.02 \\
\hline & $\mathrm{CO}$ & 170.5 & & & & 170.3 & & -0.2 & \\
\hline & $\mathrm{NH}$ & & $8.19, \mathrm{~d}(3.4)$ & & & & $8.17, \mathrm{~d}(4.5)$ & & -0.02 \\
\hline & $\alpha$ & 52.8 & 4.18 & & & 53.0 & $4.18, \mathrm{~m}$ & 0.2 & 0.00 \\
\hline & $\beta$ & 36.0 & $2.96,2.79$ & & & 35.7 & $2.96,2.80$ & -0.3 & $0.00,0.01$ \\
\hline & $\mathrm{C} 1$ & 124.3 & & $128.4^{\mathrm{b}}$ & & 128.5 & & $0.1^{\mathrm{c}}$ & \\
\hline & $\mathrm{C} 2$ & 116.2 & 6.44, brs & & & 116.3 & $6.44, \mathrm{~d}(2.1)$ & 0.1 & 0.00 \\
\hline DOPA-8 & $\mathrm{C} 3$ & 145.9 & & & & 146.2 & & 0.3 & \\
\hline & $\mathrm{C} 4$ & 146.7 & & & & 146.7 & & 0.0 & \\
\hline & $\mathrm{C} 5$ & 117.4 & $6.80, \mathrm{~d}(8.2)$ & & & 117.3 & $6.80, \mathrm{dd}(8.2,1.9)$ & -0.1 & 0.00 \\
\hline & $\mathrm{C6}$ & 114.8 & 6.64 & $125.0^{\mathrm{b}}$ & & 124.9 & $6.66, d(8.2)$ & $-0.1^{c}$ & 0.02 \\
\hline & $\mathrm{CO}$ & 169.8 & & & & 170.0 & & 0.2 & \\
\hline & $\mathrm{OH}$ & & & & & & $9.26 \mathrm{brs}$ & & \\
\hline
\end{tabular}

\footnotetext{
a as reported, ref. 4.
}

${ }^{b}$ the Tyr-3 aromatics are misassigned in ref. 4 to additional peaks that are not present in the synthetic material or seongsanamides A or D. No $1 D^{13} \mathrm{C} N M R$ is provided in ref 4 , and no cross peaks for the aromatic Cs are present in the 2D NMR spectra so reassignment of Tyr-3 C2,3,5,6 peaks is not possible. Recalculation of the Tyr-3 $\beta C$ and DOPA C1,C6 shifts are from the HMQC spectrum cross peaks.

c The equivalent signals in seongsanamides A, C \& D are all within 0.5 ppm. 


\section{References:}

1. Chen, C.; Zhu, Y.-F.; Wilcoxen, K. J. Org. Chem. 2000, 65, 2574-2576.

2. Kotha, S.; Goyal, D.; Thota, N.; Srinivas, V. Eur. J. Org. Chem. 2012, 2012, 1843-1850.

3. Armstrong, A.; Brackenridge, I.; Jackson, R. F.; Kirk, J. M. Tetrahedron Lett. 1988, 29, 24832486.

4. Kim, G. J.; Li, X.; Kim, S.-H.; Yang, I.; Hahn, D.; Chin, J.; Nam, S.-J.; Nam, J.-W.; Nam, D. H.; Oh, D.-C., Chang, H. W.; Choi, H. Org. Lett. 2018, 20, 7539-7543 